\title{
EFFECT OF MACROSCOPIC WEAR ON FRICTION IN LUBRICATED CONCENTRATED CONTACTS
}

Ioan Crăcăoanu 
De promotiecommissie is als volgt samengesteld:

prof.dr.ir. F. Eising, Universiteit Twente, voorzitter en secretaris

prof.dr.ir. D.J. Schipper, Universiteit Twente, promotor

prof.dr.ir. R. Akkerman, Universiteit Twente

prof.dr.ir. J. Huétink, Universiteit Twente

prof.dr.ir. W.A. Poelman, Universiteit Twente

prof.dr.ir. S. Crețu, Universiteit, Gh. Asachi, Roemenië

dr.ir. A. van Beek, Universiteit Delft

EFFECT OF MACROSCOPIC WEAR ON FRICTION IN LUBRICATED CONCENTRATED CONTACTS

PhD Thesis, University of Twente, Enschede, The Netherlands

Ioan Crăcăoanu

December 2010

Keywords: friction, wear, Stribeck curve, mixed lubrication, film thickness, hydrodynamic effects.

Cover design by Ioan Crăcăoanu

Printed by Wöhrmann Print Service, Zutphen, The Netherlands

ISBN 978-90-365-3095-8

DOI: $10.3990 / 1.9789036530958$

Copyright $\odot 2010$ by I. Crăcăoanu, Enschede, The Netherlands

All rights reserved. 


\title{
EFFECT OF MACROSCOPIC WEAR ON FRICTION IN LUBRICATED CONCENTRATED CONTACTS
}

\section{PROEFSCHRIFT}

\author{
ter verkrijging van \\ de graad van doctor aan de Universiteit Twente, \\ op gezag van de rector magnificus, \\ prof.dr. H. Brinksma, \\ volgens besluit van het College voor Promoties \\ in het openbaar te verdedigen \\ op donderdag 2 december 2010 om 13.15 uur
}

door

Ioan Crăcăoanu

geboren op 18 januari 1982

te Piatra-Neamt, Roemenië 
Dit proefschrift is goedgekeurd door:

de promotor: prof.dr.ir. D.J. Schipper 
to Diana in memory of my father Ion and grandmother Maria 



\section{Summary}

Wear is considered one of the main challenges in the twenty-first century for engineers and designers of mechanical systems. The objective is to understand the wear mechanisms and to seek new solutions - materials, lubricants, additives - to extend the lifetime of components, enable scheduled maintenance and replacement intervals.

Research conducted during the past decades shows that wear can be minimized but not eliminated from systems operation due to a large number of parameters which are influencing the evolution of this phenomenon: load, velocity, temperature, type of lubrication as well as the surface roughness.

Depending on operation conditions, the occurrence of wear leads to a change in the macro contact geometry of the components. In time, this will affect the functioning of the components, for example: high friction for brakes, clutches and transmissions or low friction for cylinder-piston contact, cam-follower and gears.

In this thesis the influence of macroscopic wear on friction in lubricated sliding concentrated contacts is investigated. Experimental wear and friction tests were conducted on different types of lubricated contacts: line, point and elliptical. These tests have shown a change in contact geometry and in operating regime of the systems, i.e. friction level. To understand this, a relation between wear, contact geometry and minimum film thickness is made.

In a lubricated contact three zones are distinguished: inlet, contact and outlet zone. The inlet zone dictates the formation of the minimum film thickness between contacting surfaces. When wear is present the contact geometry changes, leading to a modification in pressure distribution. Changes in separation due to wear are modeled based on hydrodynamic theory and are incorporated in a deterministic mixed lubrication friction model. Using this model the transition between the lubrication regimes, as shown in a Stribeck curve, can be predicted.

The experimentally obtained results are in agreement with the theoretical simulations. It is shown that increased wear leads to a decreased friction level resulting from the occurrence of the hydrodynamic effects due to a reduced contact pressure. This causes a change in the operating regime of the system. In the one case this changed regime can be considered to be the main cause of failure in a system, whereas in another system it means smooth operation after a period of running-in. 
The theoretical results are presented in a generalized Stribeck curve. From this, it is possible to select the parameters such that the components of a lubricated system operate in the preferred regime in order to control friction and minimize wear. 


\section{Samenvatting}

Slijtage wordt gezien als één van de belangrijkste aandachtspunten voor ingenieurs en ontwerpers van mechanische systemen in de eenentwintigste eeuw. Het doel is om slijtagemechanismes te begrijpen en nieuwe oplossingen te vinden op het gebied van materialen, smeermiddelen en smeermiddeltoevoegingen om de levensduur van componenten te verlengen, gepland onderhoud mogelijk te maken en vervangingsintervallen te verlengen.

Uit onderzoek dat in de afgelopen tientallen jaren is uitgevoerd blijkt dat slijtage van systemen kan worden geminimaliseerd, maar niet geëlimineerd. Dit is het gevolg van het grote antal parameters dat van invloed is op de evolutie van slijtage: belasting, snelheid, temperatuur, soort van smering alsmede de oppervlakteruwheid.

Afhankelijk van de condities waaronder een systeem opereert kan slijtage leiden tot een verandering van de macroscopische contactgeometrie van componenten. $\mathrm{Na}$ verloop van tijd zal dit het functioneren van de componenten beïnvloeden. Voorbeelden zijn hoge wrijving in remmen, koppelingen en versnellingen en lage wrijving tussen cilinder en zuiger, nok en volger en tussen tandwielen.

In dit proefschrift wordt de invloed van macroscopische slijtage op de wrijving in gesmeerde, glijdende geconcentreerde contacten onderzocht. Experimenteel slijtage- en wrijvingsonderzoek is uitgevoerd aan verschillende soorten gesmeerde contacten: lijncontacten, puntcontacten en elliptische contacten. Uit deze tests bleek een verandering van de contactgeometrie en van het smeringsregime, ofwel het wrijvingsniveau, in het systeem. Om dit te begrijpen is een verband gelegd tussen slijtage, contactgeometrie en minimale scheiding tussen de loopvlakken.

In een gesmeerd contact worden drie zones onderscheiden: de inlaat, het contact en de uitlaat zone. De inlaat zone is bepalend voor de minimale filmdikte tussen de twee oppervlakken. Als gevolg van slijtage verandert de contactgeometrie, resulterend in een aangepaste drukverdeling. Veranderingen in de separatie tussen de twee oppervlakken als gevolg van slijtage zijn gemodelleerd op basis van de hydrodynamische theorie en toegepast in een deterministisch model voor de wrijving in het gemengde smeringsregime. Met behulp van dit model kan de transitie tussen de smeringsregimes, als aangegeven in de Stribeck curve worden bepaald. 
De experimenteel behaalde resultaten zijn in overeenstemming met de theoretische simulaties. Er is getoond dat een toename van de slijtage leidt tot een afname van het wrijvingsniveau, als gevolg van het optreden van hydrodynamische effecten door de lage contactdruk. Dit veroorzaakt een verandering van het regime waarin het systeem opereert. Aan de ene kant kan deze verandering van regime de belangrijkste oorzaak zijn voor het falen van een systeem, aan de andere kant kan het betekenen dat een systeem goed functioneert na een periode van inlopen.

De theoretische resultaten zijn gepresenteerd in een gegeneraliseerde Stribeck curve. Met deze curve is het mogelijk de parameters zo te selecteren dat de componenten van een gesmeerd systeem in het optimale smeringsregime opereren waardoor de wrijving gecontroleerd kan worden en de slijtage geminimaliseerd. 


\section{Acknowledgements}

By finishing this doctoral thesis, another stage of my life ends. I came to the University of Twente in 2006 as a master student and then for four years I had the opportunity to work as a doctoral student in the Surface Technology and Tribology group. This was a privilege for me since the Dutch school of engineering is one of the best in the world.

Elaborating this doctoral thesis was a great challenge for me and gave me the chance to turn to good account the knowledge accumulated in the previous years of study. Therefore I would like to express my deep appreciation and gratitude for all my Romanian professors that contributed over time to my professional formation and I would like to remember professor Spiridon Crețu and professor Edward Rakoşi from the "Gh. Asachi" Technical University, Iaşi.

During the four years spent in the Netherlands I was fortunate to meet and know wonderful people and I learnt something special from each of them. Supervisors, colleagues or friends, I have plenty of reasons to sincerely thank you.

It is natural to start with professor Dik Schipper, my promoter and my supervisor, the first Dutchman with whom I came into contact and who made my adaptation here easier and more pleasant. I thank you for your encouragement, guidance and support offered in my research work, for the clear formulation of ideas and objectives that appeared following our discussions, for the pertinent observations related to the writing of the thesis, for your patience and attention. For all these and for all the other reasons that do not come to my mind at this moment, thank you.

I also thank and appreciate my team fellows with whom I collaborated: Arjen Brandsma, Rob Bosman, Loredana Deladi, Irinel Faraon, Bert Pennings, Han Pijpers and Andreas Vogt. Special thanks to Erik, Walter, Willie and Laura with whom I worked in the experimental part of my thesis and to Belinda and Debbie who guided and informed me in terms of the difficulties of administrative order.

The list would not be full if I did not remember my colleagues: Adeel, Agnieszka, Dinesh, Gerrit, Jiupeng, Mahdiar, Marc, Martijn, Matthijn, Natalia, Noor, Radu and Xiao. Together, we have succeeded in forming a small international family and creating a very pleasant work environment where the talks during the lunch break became extremely interesting and memorable at the same time.

These years have been a journey full of challenges both professionally and personally, but the end of this journey also means the beginning of a new one, 
hopefully as beautiful and fascinating as this one. My best thoughts for you and rest assured that each of you already occupies a special place in my heart.

I dedicate this thesis to Diana, my wife whose love, respect and trust accompanied me every step and gave me the strength to overcome the difficult moments.

Finally, I would also like to thank my family, friends and relatives from Romania, and I will do this in Romanian.

Un noian de sentimente mă copleşeşte, pornind de la bucurie, mulțumire sau împlinire şi până la speranța unui nou început. Sunt fericit pentru titlul de doctor care îmi va fi acordat de către universitatea olandeză şi care răsplăteşte patru ani de muncă dar şi de sacrificii.

Fără îndoială, o parte din reuşită o datorez susținerii care a venit din partea celor de acasă. Prin fiecare vorbă, gând sau gest mărunt am conştientizat că vă am alături, fie că este vorba de părinți şi bunici prezenți in aceasta lume sau de cei care nu mai sunt printre noi, fie că este vorba de frați, rude sau prieteni dragi.

Indiferent de locul în care vă aflaţi şi chiar dacă nu vă numesc aici pe fiecare in parte, vă mulțumesc tuturor pentru încurajările şi gândurile voastre care m-au ajutat enorm şi au făcut ca depărtarea de casă să nu fie aşa de mare.

Peste toate aceste trăiri îmi vin în minte câteva cuvinte pline de sens, care exprimă un adevăr simplu dar care sună mai clar şi mai actual ca niciodată: "Nihil sine Deo!". 


\section{Contents}

SUMMARY ............................................................................................................................... VII

SAMENVATTING ....................................................................................................................... IX

ACKNOWLEDGEMENTS ................................................................................................... XI

CONTENTS ....................................................................................................................................XIII

NOMENCLATURE ...............................................................................................................XVII

CHAPTER 1 INTRODUCTION................................................................................... 1

1.1 TRIBOLOGY - FRICTION, WEAR AND LUBRICATION ................................................ 1

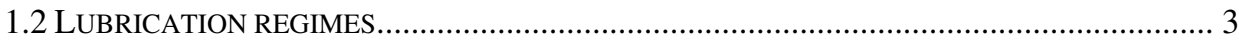

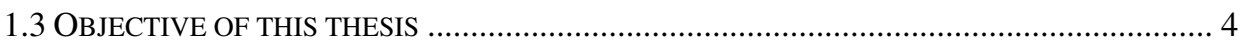

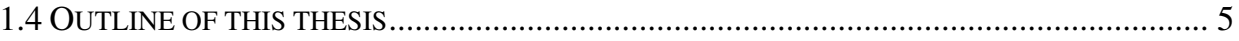

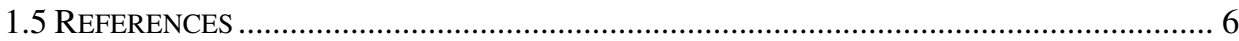

CHAPTER 2 WEAR IN LUBRICATED SYSTEMS ............................................... 7

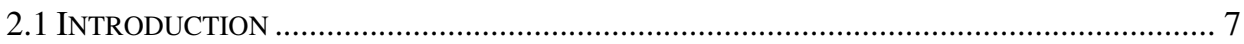

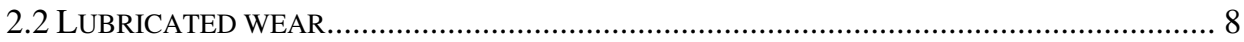

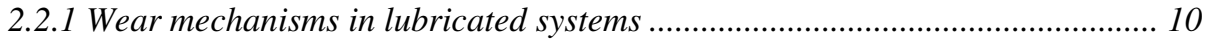

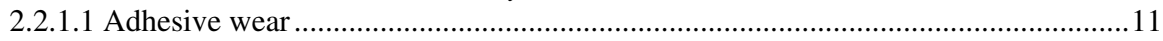

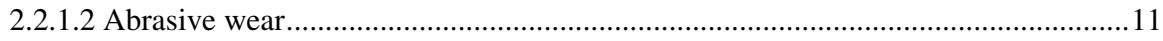

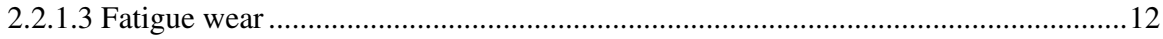

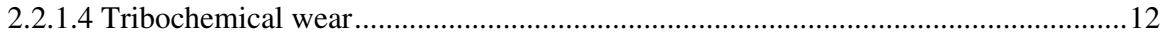

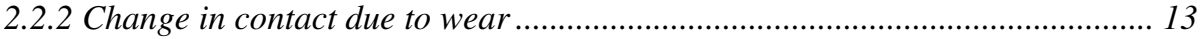

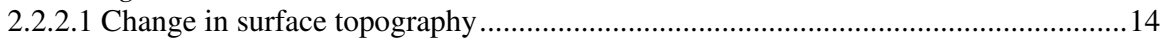

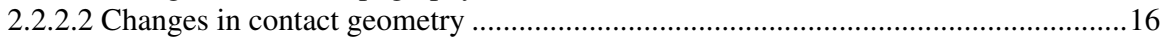

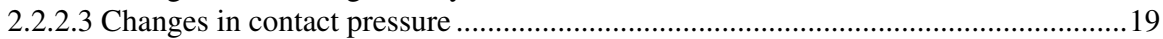

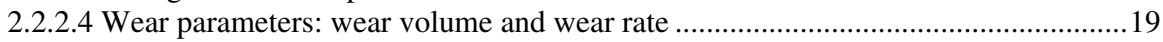

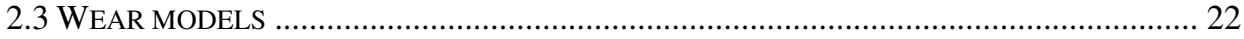

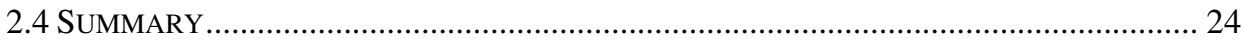

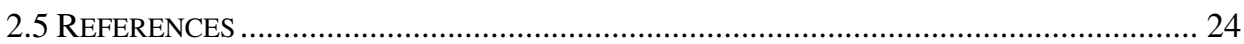

CHAPTER 3 FILM THICKNESS IN WORN LUBRICATED CONCENTRATED

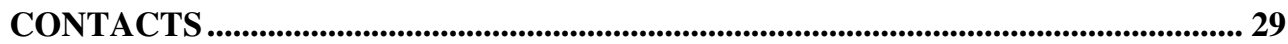

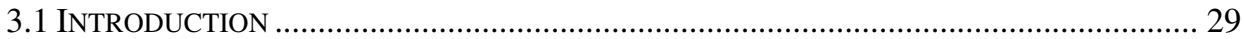

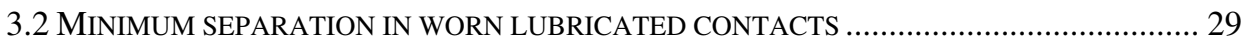

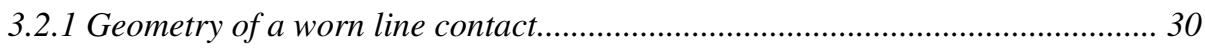

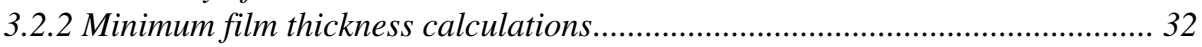

3.2.3 Minimum film thickness in worn elliptical and point contacts .......................... 38

3.3 INFLUENCE OF ELASTICITY ON THE MINIMUM FILM THICKNESS IN WORN LUBRICATED

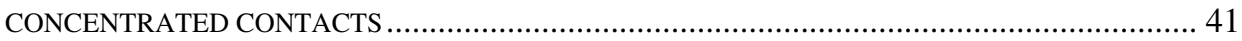

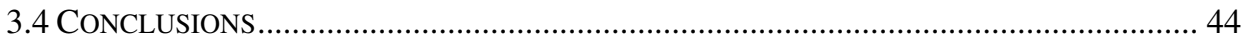

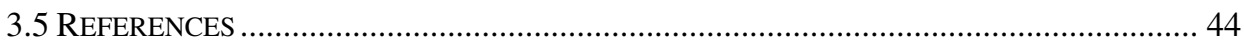




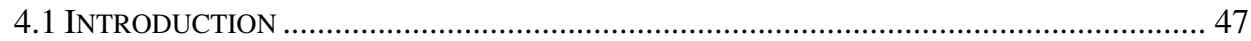

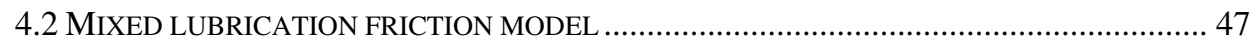

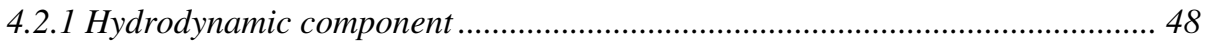

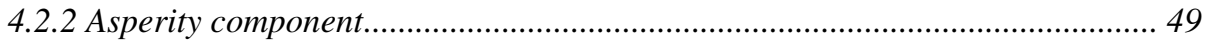

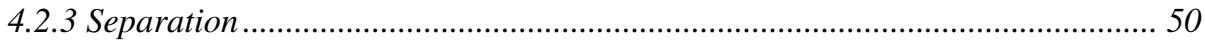

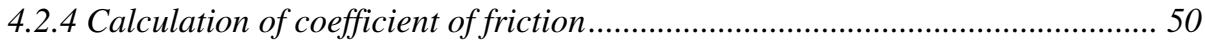

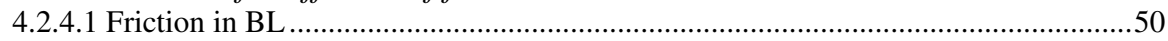

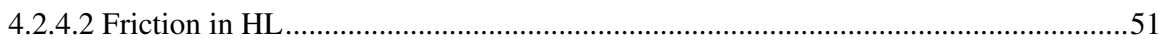

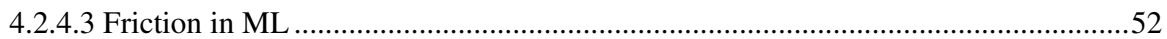

4.3 STRIBECK CURVE CALCULATION FOR WORN LUBRICATED CONTACTS ....................... 52

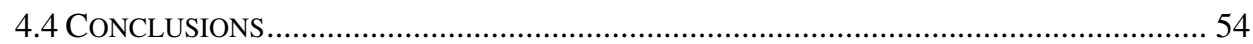

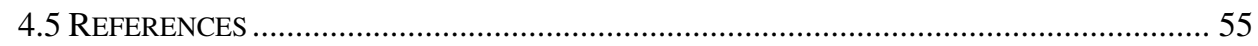

CHAPTER 5 EXPERIMENTAL RESULTS...................................................... 57

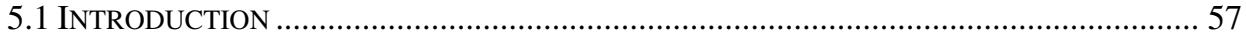

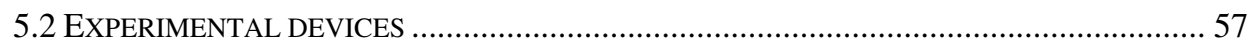

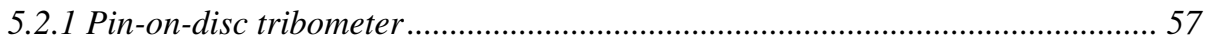

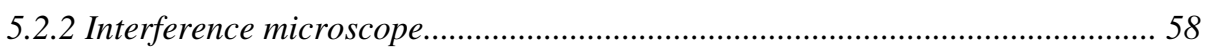

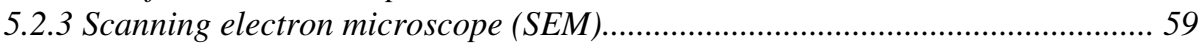

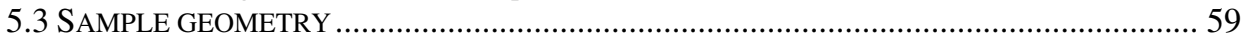

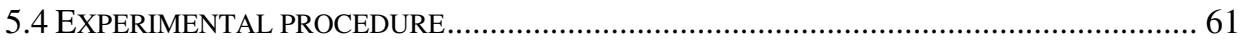

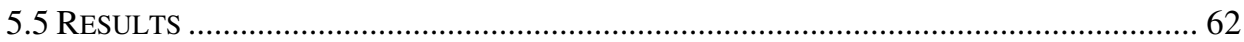

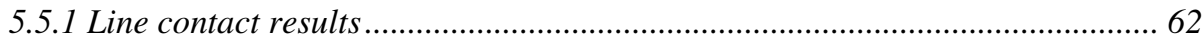

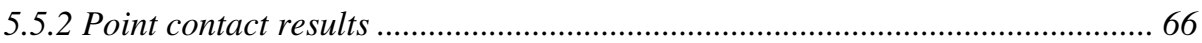

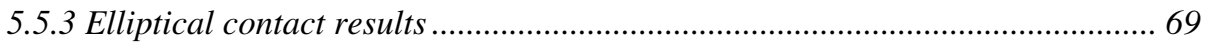

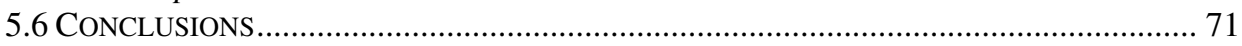

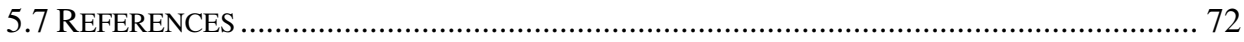

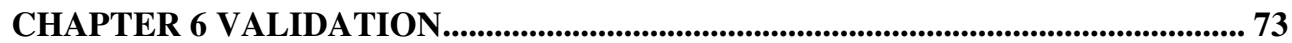

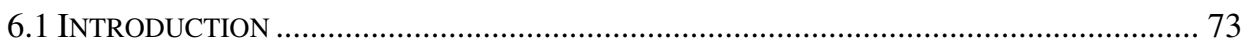

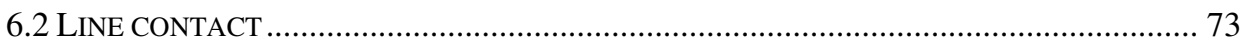

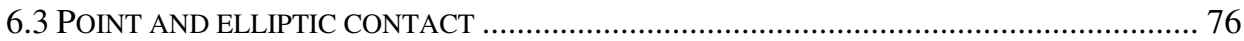

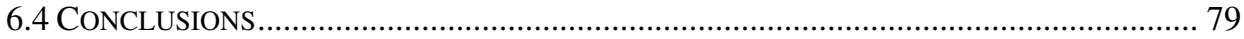

CHAPTER 7 EVOLUTION OF THE STRIBECK CURVE IN TIME........................ 81

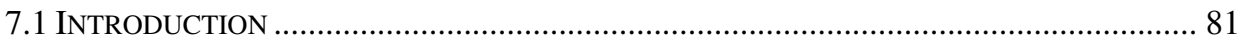

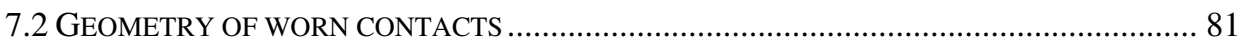

7.2.1 Evolution of line and point contacts geometry in time .................................... 81

7.3 EVOLUTION OF THE STRIBECK CURVE IN TIME FOR WORN LINE CONTACTS ............... 86

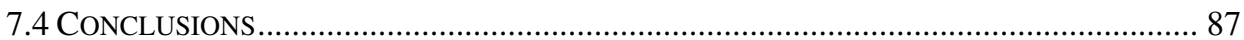

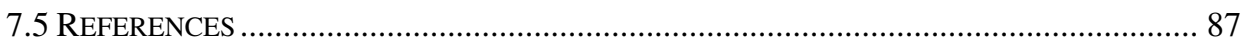

CHAPTER 8 CONCLUSIONS AND RECOMMENDATIONS ................................. 89

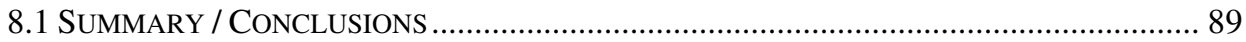




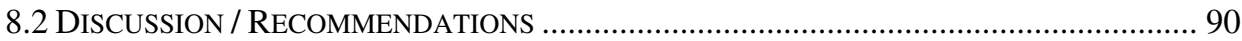

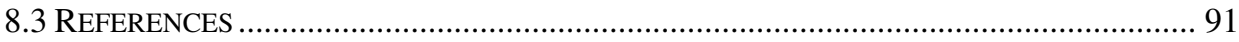

APPENDIX A. HERTZIAN CONTACTS ....................................................... 95

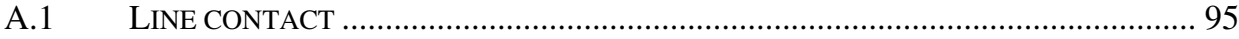

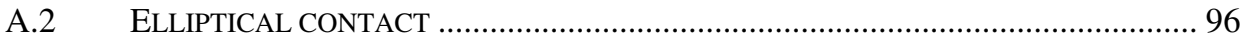

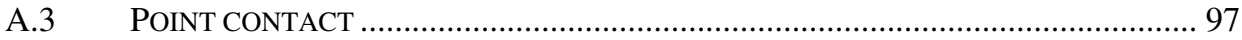

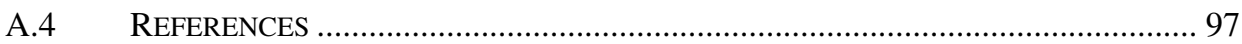

APPENDIX B. DEFINITION OF ROUGHNESS PARAMETERS ...................... 99

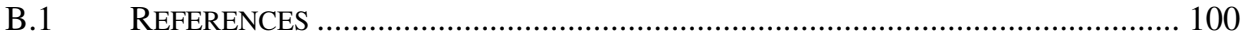

APPENDIX C. FILM THICKNESS IN CONCENTRATED CONTACTS

WITHOUT WEAR101

C.1 MINIMUM FILM THICKNESS FOR THE LINE CONTACT SITUATION ...................... 101

C.2 MINIMUM FILM THICKNESS FOR THE ELLIPTICAL CONTACT SITUATION ............ 102

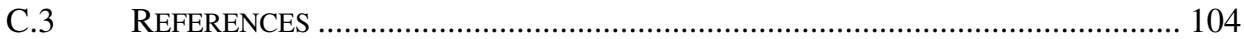

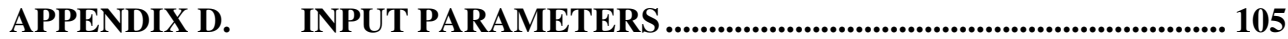




\section{Nomenclature}

a semi-axis of contact ellipse in x sliding direction [m]

$\mathrm{a}_{\mathrm{H}}$ radius of the Hertzian point contact [m]

$\mathrm{A}_{\mathrm{C}}$ total asperity contact area $\left[\mathrm{m}^{2}\right]$

$\mathrm{A}_{\mathrm{H}} \quad$ hydrodynamic contact area, $\mathrm{A}_{\mathrm{H}}=\mathrm{A}_{\mathrm{nom}}-\mathrm{A}_{\mathrm{C}} \quad\left[\mathrm{m}^{2}\right]$

$A_{i} \quad$ contact area of the $i^{\text {th }}$ asperity contact $\quad\left[\mathrm{m}^{2}\right]$

$\mathrm{A}_{\text {nom }}$ the nominal contact area $\left[\mathrm{m}^{2}\right]$

b semi-axis of contact ellipse in y direction [m]

$b_{\mathrm{H}}$ half contact width of the Hertzian line contact [m]

B length of the line contact (cylinder) [m]

$\mathrm{f}$ coefficient of friction [-]

$\mathrm{f}(\alpha, \mathrm{G})$ function depending on $\alpha$ and (inlet) geometry

$\mathrm{E}_{\mathrm{p}}$ modulus of elasticity of the pin [Pa]

$\mathrm{F}_{\mathrm{C}}$ load carried by the interacting asperities $[\mathrm{N}]$

$\mathrm{F}_{\mathrm{f}, \mathrm{BL}}$ friction force in $\mathrm{BL}$ regime $[\mathrm{N}]$

$\mathrm{F}_{\mathrm{f}, \mathrm{HL}}$ friction force in $\mathrm{HL}$ regime $\quad[\mathrm{N}]$

$\begin{array}{ll}\mathrm{F}_{\mathrm{f}, \mathrm{ML}} \text { friction force in ML regime } & {[\mathrm{N}]}\end{array}$

$\mathrm{F}_{\mathrm{H}} \quad$ load carried by the hydrodynamic component $[\mathrm{N}]$

$\begin{array}{lll}\mathrm{F}_{\mathrm{N}} \text { normal load } & {[\mathrm{N}]}\end{array}$

h film thickness specific to xoy coordinate system [m]

h' film thickness specific to x'o'y'coordinate system [m]

$\mathrm{h}_{0 \mathrm{i}} \quad$ parameter to define worn profile after i cycles [m]

$\mathrm{h}_{\mathrm{i}}{ }^{\mathrm{e}}$ the elastic deformation normal to the contact [m]

$\mathrm{h}_{\mathrm{g}}$ film thickness given by the geometry [m]

$\mathrm{h}_{\text {min }}$ minimum film thickness [m]

$\mathrm{h}_{\text {minEP }}$ minimum film thickness in EP regime [m]

$\mathrm{h}_{\text {minRI }}$ minimum film thickness for RI regime [m] 


\begin{tabular}{|c|c|c|}
\hline $\mathrm{h}_{\mathrm{s}}$ & separation & {$[\mathrm{m}]$} \\
\hline $\mathrm{h}_{\mathrm{wi}}$ & parameter to define worn profile after i cycles & {$[\mathrm{m}]$} \\
\hline $\mathrm{k}$ & wear rate & {$\left[\mathrm{mm}^{3} / \mathrm{N} \cdot \mathrm{m}\right]$} \\
\hline $\mathrm{L}_{\mathrm{w}}$ & half contact width or half wear scar diameter & {$[\mathrm{m}]$} \\
\hline $\mathrm{n}$ & power coefficient $(\sim 0.7)$ & {$[-]$} \\
\hline $\mathrm{N}$ & numbers of the micro contacts & {$[-]$} \\
\hline $\mathrm{p}$ & pressure & {$[\mathrm{Pa}]$} \\
\hline $\mathrm{p}_{\max }$ & maximum pressure for the inlet zone & {$[\mathrm{Pa}]$} \\
\hline $\mathrm{p}_{\text {mean }}$ & mean contact pressure & {$[\mathrm{Pa}]$} \\
\hline $\mathrm{p}_{\mathrm{C}}$ & pressure carried by the interacting asperities & {$[\mathrm{Pa}]$} \\
\hline $\mathrm{p}_{\mathrm{H}}$ & pressure carried by the hydrodynamic component & {$[\mathrm{Pa}]$} \\
\hline $\mathrm{p}_{\mathrm{N}}$ & pressure exerted by the normal load & {$[\mathrm{Pa}]$} \\
\hline $\mathrm{r}_{\text {track }}$ & radius of the wear scar track & {$[\mathrm{m}]$} \\
\hline $\mathrm{R}$ & radius of the cylinder & {$[\mathrm{m}]$} \\
\hline $\mathrm{R}_{\mathrm{p}}$ & radius of the sphere & {$[\mathrm{m}]$} \\
\hline $\mathrm{R}_{\mathrm{x}}$ & radius of the spherical roller in $\mathrm{x}$ direction & {$[\mathrm{m}]$} \\
\hline $\mathrm{R}_{\mathrm{y}}$ & radius of the spherical roller in y direction & {$[\mathrm{m}]$} \\
\hline $\mathrm{R}_{\mathrm{w}}$ & worn radius & {$[\mathrm{m}]$} \\
\hline $\mathrm{s}$ & sliding distance & {$[\mathrm{m}]$} \\
\hline$S_{\max }$ & maximum sliding distance & {$[\mathrm{m}]$} \\
\hline $\mathrm{v}$ & velocity & {$[\mathrm{m} / \mathrm{s}]$} \\
\hline$v^{\mathrm{dif}}$ & relative motion between the opposing surfaces & {$[\mathrm{m} / \mathrm{s}]$} \\
\hline $\mathrm{V}$ & volume of the material removed & {$\left[\mathrm{mm}^{3}\right]$} \\
\hline w & wear depth & {$[\mathrm{m}]$} \\
\hline $\mathrm{w}_{\mathrm{T}}$ & total wear depth & {$[\mathrm{m}]$} \\
\hline $\mathrm{x}$ & spatial Cartesian coordinates & {$[\mathrm{m}]$} \\
\hline $\mathrm{X}$ & parameter $\mathrm{X}=\mathrm{x}+\mathrm{L}_{\mathrm{w}}$ & {$[\mathrm{m}]$} \\
\hline $\mathrm{y}$ & spatial Cartesian coordinates & {$[\mathrm{m}]$} \\
\hline
\end{tabular}




\section{Greek symbols}

$\alpha \quad$ viscosity-pressure coefficient $\quad\left[\mathrm{Pa}^{-1}\right]$

$\beta_{\mathrm{RI}} \quad$ parameter to define the minimum film thickness in RI $\quad\left[\mathrm{m}^{2}\right]$

$\gamma$ coefficient [-]

$\gamma_{1}$ coefficient [-]

$\gamma_{2}$ coefficient [-]

$\dot{\gamma} \quad$ shear rate, $\dot{\gamma}=\mathrm{v}^{\mathrm{dif}} / \mathrm{h} \quad[1 / \mathrm{s}]$

$\begin{array}{lll}\delta_{\mathrm{i}} & \text { deformation depth or asperities indentation }\end{array}$

$\delta_{\mathrm{RI}} \quad$ parameter to define the minimum film thickness in RI $\quad\left[\mathrm{m}^{3 / 2}\right]$

$\Delta \mathrm{s} \quad$ increment of the sliding distance, $\Delta \mathrm{s}=2 \pi \mathrm{r}_{\text {track }} \quad$ [m]

$\eta \quad$ viscosity [Pa.s]

$\eta_{0} \quad$ viscosity at ambient pressure $\quad[\mathrm{Pa} \cdot \mathrm{s}]$

$v_{\mathrm{p}} \quad$ Poisson ratio of the pin [-]

$\tau_{\mathrm{Ci}}$ shear stress at the $\mathrm{i}^{\text {th }}$ asperity contact [Pa]

$\tau_{\mathrm{H}}$ hydrodynamic shear stress $\quad[\mathrm{Pa}]$

$\tau_{0}$ Eyring shear stress $\quad[\mathrm{Pa}]$

$\sigma \quad$ standard deviation of surface roughness $\quad[\mathrm{m}]$

\section{Abbreviations}

BL boundary lubrication regime

ML mixed lubrication regime

EHL elastohydrodynamic lubrication regime

HL hydrodynamic lubrication regime

RI rigid isoviscous regime 
EI elasto isoviscous regime

RP rigid piezoviscous regime

EP elasto piezoviscous regime 


\section{Chapter 1 Introduction}

\subsection{Tribology - friction, wear and lubrication}

Tribology is defined as the science and technology of interacting surfaces in relative motion dealing with the phenomena (friction and wear) occurring between interacting surfaces related to physics, mechanics, metallurgy and chemistry [1]. In order to control friction and wear these surfaces can be lubricated.

A car is an assembly of a great number of systems (see Figure 1.1) like the transmission, engine, brakes, tires, suspension and fuel injection in which surfaces operate under different conditions: dry and lubricated.

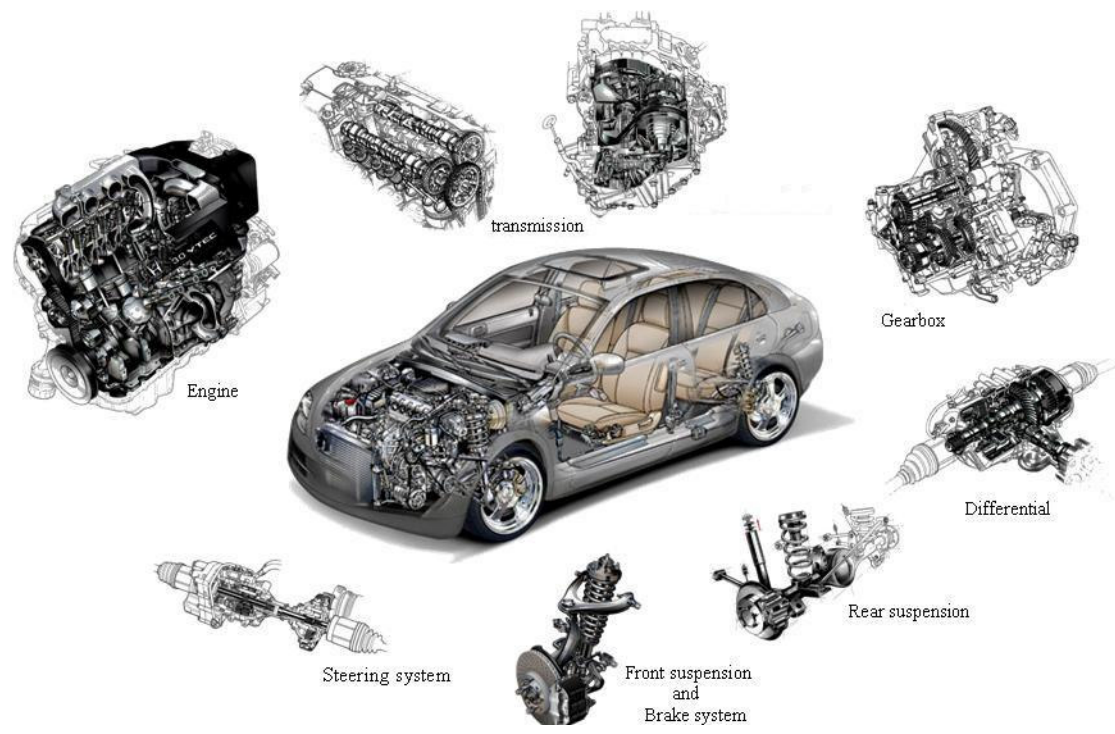

Figure 1.1 Examples of systems.

The tribosystems are reference units in tribology and are composed of two bodies which are interacting with each other in the presence of a lubricant and in a specific environment, schematically shown in Figure 1.2. The aforementioned car systems contain such tribosystems.

If the lubricant is not able to separate the surfaces, contact between the surfaces takes place at asperity level (microscopic contact). The level of contact depends on the operating parameters: load, velocity, temperature, type of lubrication as well as 
the roughness [2]. In time, due to friction between the surface components, wear appears and changes the micro (roughness) and macro geometry and as a result this leads to energy losses (for example: more than one quarter of the power is lost by friction in the engine and transmission system) [3] and finally to the failure of a system.

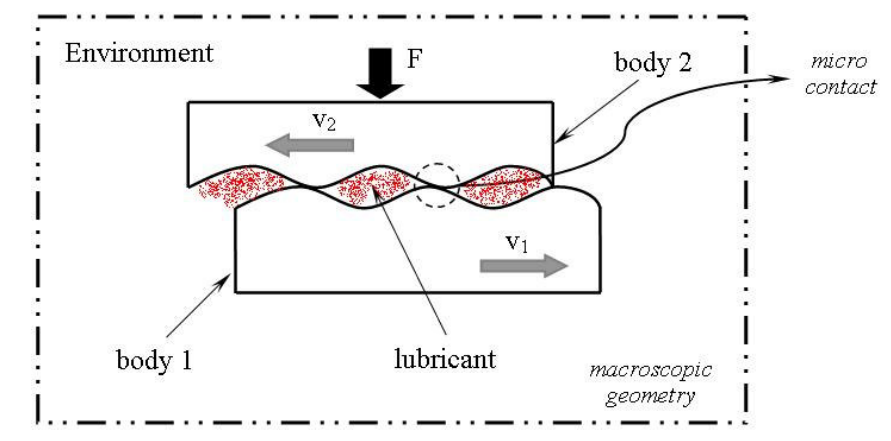

Figure 1.2 Schematic representation of a tribosystem.

Worldwide, wear is considered as the main failure phenomenon of tribosystems and is defined as the loss of material from contacting surfaces in relative motion being controlled by the properties of the material (hardness, ductility, thermal properties, etc.), the environment (lubricant type, temperature) and operational conditions (surface topography, load, velocity) and the geometry of the contacting surfaces [4]. During the lifetime of a system lubricated components undergo three stages towards failure [5] and are affected by nearly as many variables as in human life [6].

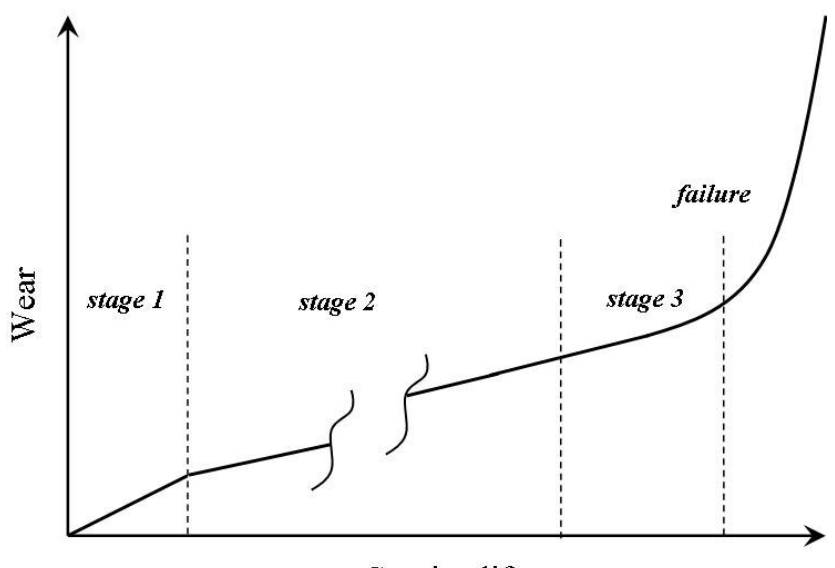

Service life

Figure 1.3 Service life diagram in sliding lubrication reproduced from [5]. 
In stage 1 (running-in) wear exists due to accommodation of the surfaces and the surface topography changes during the running-in process by removal of the high asperities of the contacting surfaces. As a function of the operational parameters, tribolayers can be activated by interaction (physical-chemical, colloidal-chemical or chemical) between the rubbing surfaces and additives in the lubricant (antiwear and EP additives), having a protective role against wear [7].

The operating period of a system in stage 2 (service life) depends on the properties of the tribolayers, like hardness and thickness, and is characterized by a constant increase in wear. During this period modification in the subsurface structure (plastic deformation, micro-crack initiation and development of these) takes place due to large plastic strains and high contact temperatures, due to friction.

In stage 3 (surface deterioration) micro-fatigue takes place in the contacting surfaces due to an increase of micro-cracks below the contact area, increasing the amount of wear and finally to the failure of the system [5].

\subsection{Lubrication regimes}

Lubrication is defined as "the application of a lubricant between two surfaces in relative motion for the purpose of reducing friction and wear or other forms of surface deterioration" [1].

From the late nineteenth, early twentieth century many researchers began to develop theories related to friction and wear that occur in tribosystems. Stribeck was the first who reported the dependency of the coefficient of friction of a lubricated system as a function of velocity, in the so-called Stribeck curve [8]. Depending on the operational conditions (load, temperature and velocity) a lubricated system can operate in one of the following three lubrication regimes:

Boundary lubrication (BL) is the regime where the load is carried by the interacting asperities of the contacting surfaces (no hydrodynamic effects due to low values of velocity). In this regime the values of coefficient of friction are in the order of 0.1 0.15 , friction and wear are controlled by the protective layers built on top of the rubbing surfaces.

Under hydrodynamic lubrication conditions (HL or EHL) the lubricant film separates the contacting surfaces, due to motion, the coefficient of friction is governed by the lubricant properties and is of the order of 0.01 (in this regime the wear is considered to be zero). 


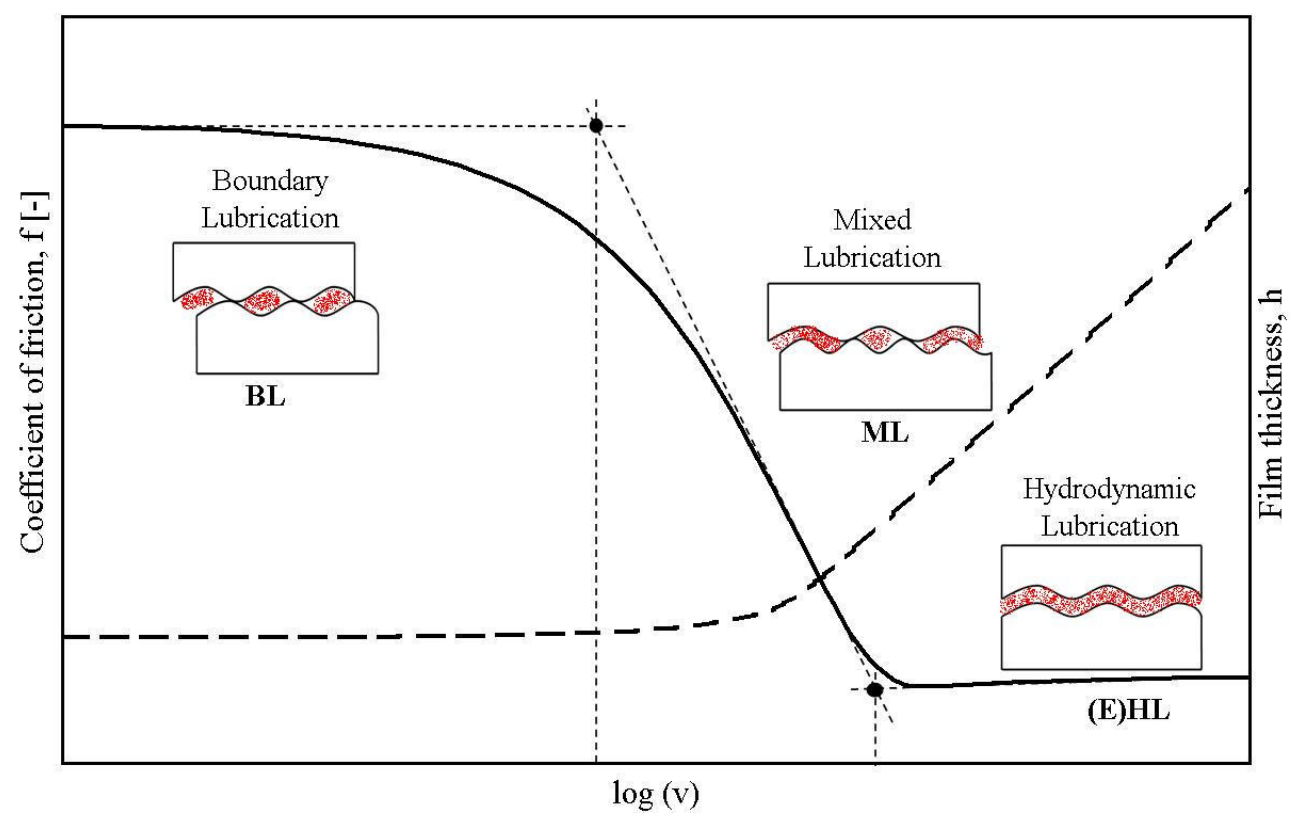

Figure 1.4 Generalized Stribeck curve and lubrication regimes.

The third lubrication regime (mixed lubrication regime ML) is considered to be a transition regime between BL and HL in which the load is shared between the hydrodynamic and asperity component.

Using the generalized Stribeck curve it is possible to select the parameters such that the components of a lubricated system operate in a preferred regime to control friction and minimize wear [9].

\subsection{Objective of this thesis}

Wear is considered to be the main challenge for engineers and designers of mechanical systems in the 21 st century due to permanent losses in industry, by trying to understand the wear mechanisms and to find new solutions (materials, lubricants, additives) for extension of the components lifetime. Depending on operational requirements: high friction (brakes, clutches, transmissions) or low friction (i.e. cylinder-piston contact) each lubricated tribosystem is designed to operate in one of the three aforementioned regimes in the Stribeck curve.

The literature shows that wear leads to changes in surface parameters [10] and [11] surface geometry [12] and [13] as a function of the operational conditions. 
How will these geometrical changes affect the operating regime of a lubricated system?

The goal of this thesis is to investigate the effect of macroscopic wear (changes in contact geometry) on friction in lubricated sliding concentrated contacts (line, point and elliptical contact). In the case of lubricated contacts three zones are distinguished: inlet, contact and outlet zone. When wear is present the contact geometry changes leading to a modification in pressure distribution whilst the inlet zone dictates the formation of the minimum separation between the contacting surfaces. For each concentrated contact changes in separation due to wear are calculated based on the hydrodynamic theory (Reynolds equation) and a mixed lubrication friction model is developed to predict the transition between the lubrication regimes of the so-called Stribeck curve. The model is validated by friction measurements performed on a pin-on-disc tribometer.

\subsection{Outline of this thesis}

The next chapter gives a literature overview on lubricated wear: classification, changes in surface topography and geometry, wear volume and wear rate.

In chapter 3 the influence of wear on the separation in line, point and elliptical contacts is calculated based on the Reynolds equation of the hydrodynamic lubrication theory. These results are compared with results from the literature. Chapter 4 presents a deterministic mixed lubrication friction model which takes into consideration changes in contact geometry due to wear. The experiments performed to validate the friction model are described in chapter 5 .

In chapter 6 theoretical results from chapter 4 will be compared with the experimental results performed on a pin-on-disc tribometer. Chapter 7 discusses the change of the Stribeck curve in time, i.e. during the lifetime of a lubricated contact. The final chapter summarizes the conclusions and the recommendations for further research. 


\subsection{References}

[1] Kajdas, C., Harvey, S.S.K and Wilusz, E., "Encyclopedia of tribology", Vol. 15, Elsevier, 1990, pp. 364.

[2] Jamari, "Running-in of rolling contacts", $\mathrm{PhD}$ thesis, University of Twente, The Netherlands, 2005.

[3] Frene, J., Nicolas, D., Degueurce, B., Berthe, D. and Godet, M: "Hydrodynamic lubrication: bearing and thrust bearing", Tribology Series, Vol. 33, 1997, p. 1.

[4] Stolarsky, T.A., "Tribology in machine design", Butterworth-Heinemann, Oxford, Great Britain, 1990, p. 19.

[5] Jisheng, E., "An investigation of lubrication mechanisms and material removal of an alloy steel in sliding lubrication", Boundary and mixed lubrication, science and applications (Dowson, D et al.), 2002, p. 351.

[6] Shigley, J.E., and Mischke, C.R., "Standard handbook of machine design", second edition, McGraw-Hill, U.S.A., 1996, chapter 6.

[7] Totten, G.E. and Liang, H. "Surface modification and mechanism", Marcel Dekker INC., New York, U.S.A., 2005, p. 414.

[8] Stribeck, R., "Die wesentlichen Eigenschaften der Gleit und Rollenlager", Zeitschrift des Vereines deutscher Ingenieure 46, 1902, pp. 1341-1348, 1432-1438 and 1463-1470.

[9] Schipper, D.J., "Transition in the lubrication of concentrated contact", $\mathrm{PhD}$ thesis, University of Twente, Enschede, The Netherlands, 1988.

[10] Jacabson, S. and Hogmark, S., "Surface modification in tribological contacts", Wear, Vol. 266, 2009, pp. 370-378.

[11] Yuan, C. Q., Peng, Z., Zhou, X.C. and Yan, X.P., "The surface roughness evolutions of wear particles and wear components under lubricated rolling wear condition", Wear, Vol. 259, 2005, pp. 512-518.

[12] Wong, P.L., Huang, P., Wang, W. and Zhang, Z., "Effect of geometry change of rough point contact due to lubricated sliding wear on lubrication", Tribology Letters, Vol. 5, 1998, pp. 265-274.

[13] Oqvist, M., "Numerical simulation of mild wear using updated geometry with different step size approaches", Wear, Vol. 249, 2001, pp. 6-11. 


\section{Chapter 2 Wear in lubricated systems}

\subsection{Introduction}

Every year the cost of losses due to wear in industry represents a significant percentage of the gross national product of each country (for example: $6-7 \%$ in USA [1]). Studies conducted in the last five decades show that the lifetime of tribological systems is influenced by the choice of the key factors that control wear: operational conditions and material properties.

The relationship used to study wear in tribosystems is Archard's law in which the wear coefficient $\mathrm{K}[-]$ is defined as product between wear rate $\mathrm{k}\left[\mathrm{mm}^{3} / \mathrm{N} \cdot \mathrm{m}\right]$ and hardness $\mathrm{H}[\mathrm{MPa}]$ of the softer material in contact.

$$
\mathrm{K}=\mathrm{k} \cdot \mathrm{H}
$$

The wear rate is not a material property and is defined as the wear volume per unit distance and unit load.

$$
\mathrm{k}=\frac{\mathrm{V}}{\mathrm{F}_{\mathrm{N}} \cdot \mathrm{s}}
$$

with: $\mathrm{V}$ total wear volume of the specific component $\left[\mathrm{mm}^{3}\right]$

$\mathrm{F}_{\mathrm{N}}$ normal load $[\mathrm{N}]$

$\mathrm{s} \quad$ sliding distance $[\mathrm{m}]$

The values for wear rates of metallic materials in sliding contact under different lubrication regimes are shown in Figure 2.1.

In the HL regime the separation between the surfaces is sufficient to prevent asperity contact and is characterized by low values of the wear rate $\left(10^{-15}\right.$ to $10^{-9}$ $\left.\mathrm{mm}^{3} / \mathrm{N} \cdot \mathrm{m}\right)$. Depending on the lubricant properties in BL the values for the wear rate increase to $10^{-6} \mathrm{~mm}^{3} / \mathrm{N} \cdot \mathrm{m}$.

If the operational conditions become severe (high loads and high temperatures) and sliding contact occurs between unlubricated surfaces then the values of wear rate may become $10^{-5}$ to $10^{-1} \mathrm{~mm} / \mathrm{N} \cdot \mathrm{m}$. 


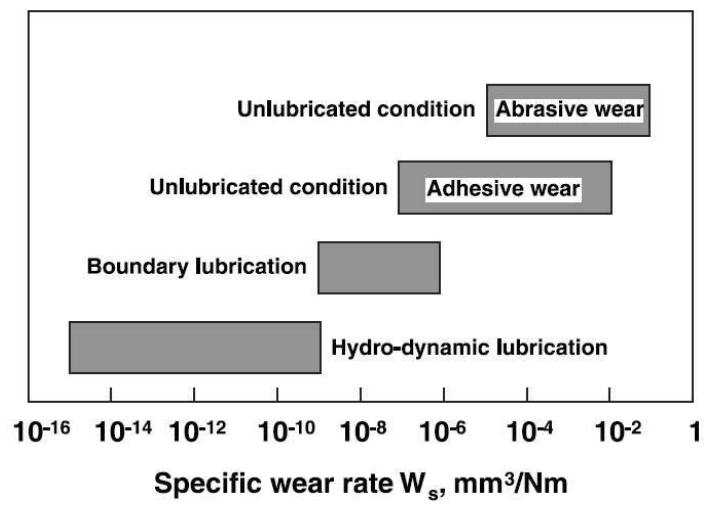

Figure 2.1 Distribution of wear rate in sliding contacts under different lubrication regimes [2].

\subsection{Lubricated wear}

The main way to reduce friction between bodies is the use of lubricants. Research studies [1] and [3] have shown that the use of lubricants does not completely reduce the appearance of wear; this phenomenon largely depends on the operational conditions of the systems.

In a lubricated system one method to evaluate wear is using a wear map which is able to provide information about the behaviour of materials under different sliding conditions and gives relationships between the dominant wear mechanisms which take place between the rubbing surfaces [4].

In 1972 Beerbower proposed a conceptual wear mechanism diagram for steel under lubricated conditions as a function of the specific film thickness [4]. According to the wear map Figure 2.2, low values of wear are obtained only if between the contacting surfaces exist a "good" lubrication (high film thickness) due to hydrodynamic effects which appear at high values of the sliding velocity (HL or EHL regime).

In the case of BL, wear is controlled by chemistry and properties of the boundary lubricating film which are dependent on reactivity and severity of operational conditions. 


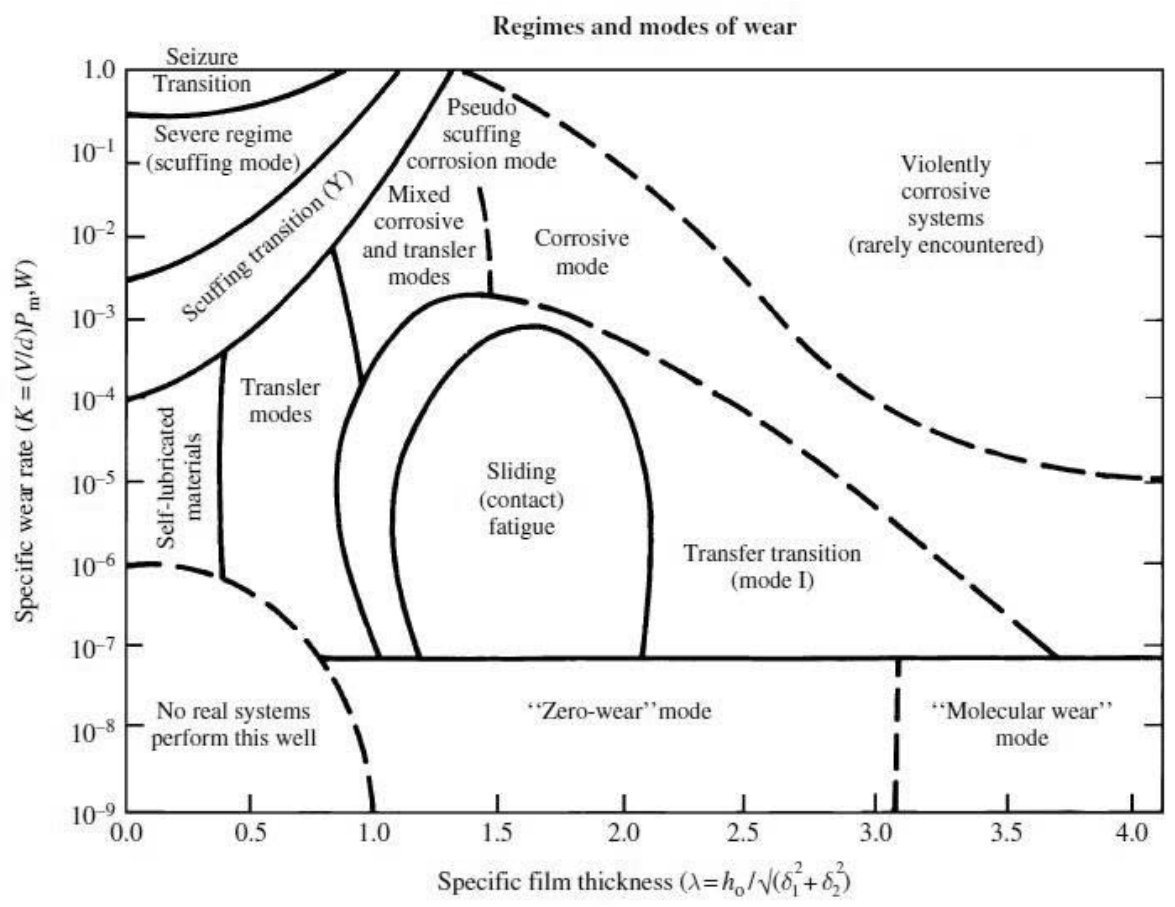

Figure 2.2 Wear map for steel under lubricated conditions [5].

Figure 2.3 indicates that wear scar evolution depends on the wear mechanism and chemical reactions between the rubbing surfaces and lubricant. For the first four samples of Figure 2.3 wear was caused by abrasion (scratches in sliding direction), the differences in size of the wear scars can be explained by different properties of the protection layers formed as a result of interaction of additives (friction modifier) and surfaces. The sample on the right-hand side of Figure 2.3 presents a different wear mechanism (clean and smooth) which involves the rubbing of the chemical film (reaction between a steel layer and active elements of FM-3) as soon it was formed.

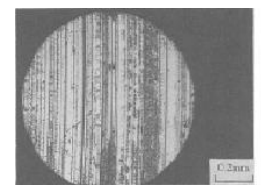

oil A parafinic oil LN

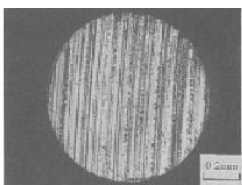

oil B oil LN+3wt\% FM-4

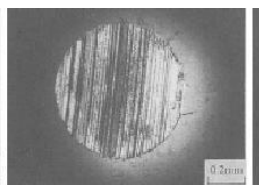

oil C

oil $\mathrm{LN}+5 \mathrm{wt} \% \mathrm{FM}-1$

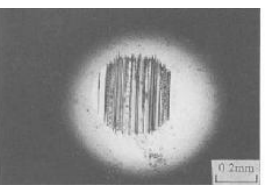

oil D

oil LN+1 wt\% FM-2

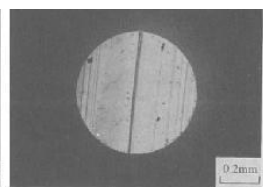

oil $\mathrm{E}$

oil LN+1wt\% FM-3

FM-1 to FM-4 - friction modifiers

Figure 2.3 Wear scars on bearing steel balls sliding against bearing steel disk at a speed of $0.785 \mathrm{~m} / \mathrm{s}$ and a sliding distance of $9.42 \mathrm{~km}[6]$. 
Another method to evaluate lubricated wear in systems is provided by the IRG transition diagram [7] which displays regimes of lubricated wear as a function of the operational parameters (normal load and sliding velocity). According to Figure 2.4 the following regimes are possible:

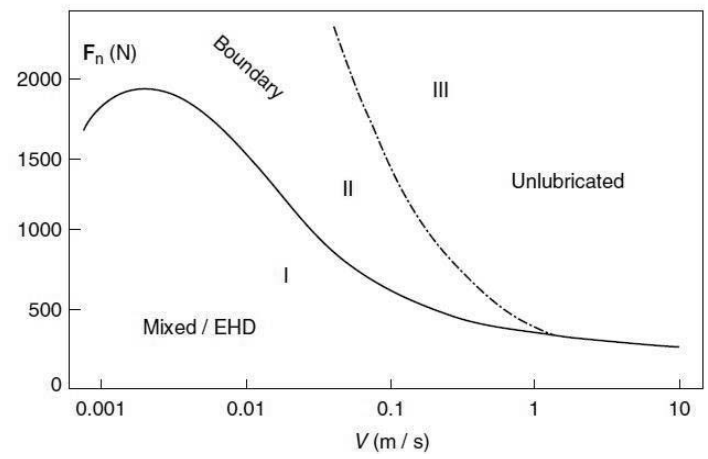

Figure $2.4 \quad$ IRG transition diagram.

- regime I corresponds to partial EHL and is characterized by low values for the coefficient of friction (0.04 to 0.1$)$ and wear rate $\left(\mathrm{k} \sim 10^{-9} \mathrm{~mm}^{3} / \mathrm{N} \cdot \mathrm{m}\right)$ and is described as a regime of mild wear, whereby the main cause for removing of material is by tribochemical wear;

- regime II is characterized by values for the coefficient of friction (0.2 to 0.4$)$ and wear rate $\left(10^{-8}\right.$ to $\left.10^{-6} \mathrm{~mm}^{3} / \mathrm{N} \cdot \mathrm{m}\right)$ due to high values of contact pressure which define BL;

- in regime III, due to increase in load, the contact between metallic asperities is inevitable (unlubricated) and leads to an increase of the coefficient of friction ( 0.5 ) and wear rate (larger than $10^{-5} \mathrm{~mm}^{3} / \mathrm{N} \cdot \mathrm{m}$ ). This regime is defined by the term "scuffing" which is associated with the breakdown of lubrication.

\subsubsection{Wear mechanisms in lubricated systems}

Wear depends on many parameters and can be classified according to the following criteria:

- function of the appearance of the wear scar: pitted, scratched, polished, fretted, gouged and scuffed;

- function of the physical mechanism which causes damage by material removal: adhesive, abrasive, fatigue and tribochemical;

- function of operational conditions: lubricated wear, unlubricated wear, sliding and rolling wear, high temperature metallic wear. 


\subsubsection{Adhesive wear}

Adhesive wear is defined as wear by transfer of material from one surface to another during relative motion due to a process of solid-phase welding [8]. In this mechanism wear particles are created due to a fracture of the softer material close to the welded junction being permanently or temporarily attached to the other surface.
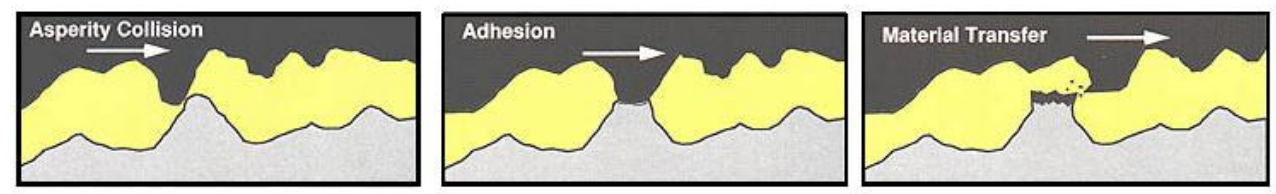

Figure 2.5 Schematic adhesive wear mechanisms [9].

Adhesive wear takes place in systems which operate in the BL or ML regime and appears due to an incorrect mounting or misalignment between components (piston/cylinders, cams and followers, gears and bearings) or severe operational conditions which can lead to the lubricant's failure. This mechanism can be prevented by ensuring that the correct type of lubricant is used (antiwear AW and extreme pressure EP additives to reduce the surface damage) and by lowering the contact loads.

\subsubsection{Abrasive wear}

Abrasive wear can be defined as removal of any part of material due to friction by hard particles and protuberances [8]. Depending on the hardness values of the rubbing surfaces two types of abrasive wear are defined: two and three body abrasive wear. The first type is characterized by the fact that asperities of the harder surface will plough through the softer surface. The second type is based on the theory that the hard removed particles are able to move freely in the contact area and form scratches.

a) two-body abrasive wear
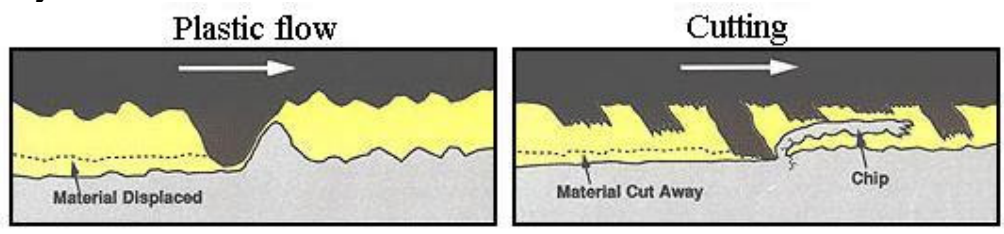
b) three-body abrasive wear
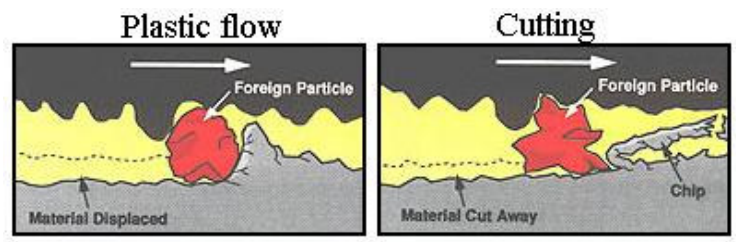

Figure 2.6 Schematic abrasive wear mechanism [9].

\subsubsection{Fatigue wear}

Removal of particles detached by fatigue arising from cyclic stress variations is defined as fatigue wear [7]. This type of wear occurs after repeated cycles where the stress cycling leads to initiation of subsurface cracks. The crack network continues to propagate with increasing of number of stress fluctuation until de cracks intersecting the surface and free metallic particles are released, resulting in a progressive loss of material from the surface [10].
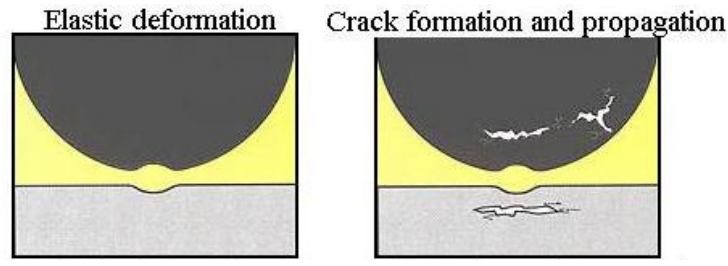

Figure 2.7 Schematic fatigue wear mechanism [9].

\subsubsection{Tribochemical wear}

Tribochemical wear is considered the mildest form of wear and its evolution is influenced by the tribolayers properties formed on top of surface asperities. Protected film formation depends on the additives [11] and nature of the rubbing surfaces [ 12 ] involving the following three mechanisms: chemisorption, decomposition and diffusion [3]. As a function of the operating conditions, chemical reactions between interacting surfaces and the environment take place and new products (tribolayers) are deposited on the surfaces. 
a)
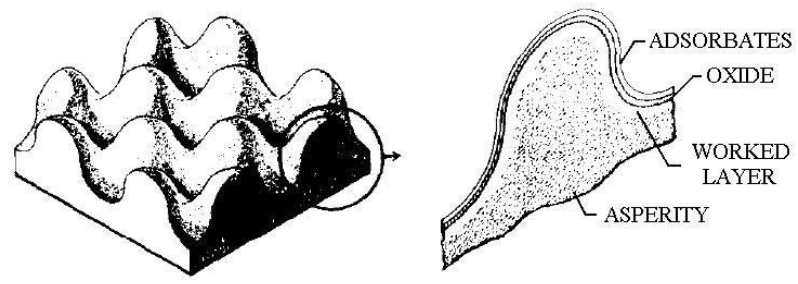

adsorbed layer $\sim 1 \mathrm{~nm}$

oxide layers $\sim 10-100 \mathrm{~nm}$

worked layers $\sim 1-100 \mu \mathrm{m}$

b)

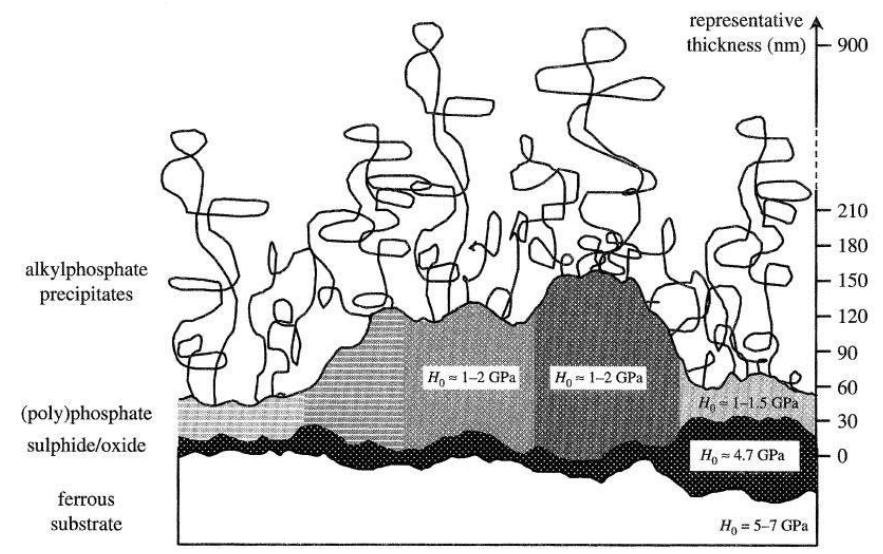

Figure 2.8 Surface and ZDDP tribolayers structure: a) structure of metal surface [13] and b) schematic structure of the ZDDP film [14].

Further asperity-asperity contacts occur due to film removal by friction, film regeneration largely depending on contact temperature (reactivity increases with increasing contact temperature). Continuous repeating of these cycles leads to the impossibility of formation of protective films.

\subsubsection{Change in contact due to wear}

Wear is considered as a dynamic phenomenon that leads to changes in operational conditions affecting the contacting surfaces through a continuous change of the following parameters: surface topography, contact geometry and contact pressure. 


\subsubsection{Change in surface topography}

The surfaces of machine elements are not perfectly smooth [15]; their topography depends on the manufacturing process [16], [17] and surface treatments [18], [19].

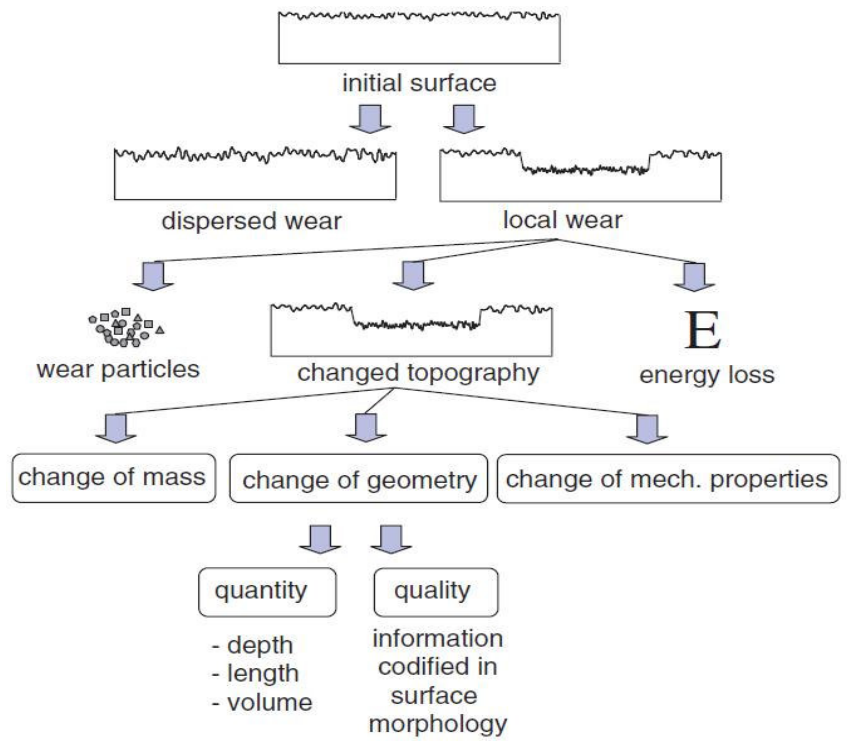

Figure 2.9 Changes in surface topography due to wear reproduced from [20].

In a lubricated system the roughness of the surface [21] has an important role in indentifying the lubrication regime using the lubrication number:

$$
\mathrm{L}=\frac{\eta_{0} \mathrm{v}}{\mathrm{pR}_{\mathrm{a}}}
$$

where: $\eta_{0} \quad$ viscosity at ambient pressure

$\mathrm{R}_{\mathrm{a}} \quad$ CLA surface roughness

v velocity

$\mathrm{p}$ mean contact pressure

Transformation of the topography of the contacting surfaces begins with the running-in process [22], [23], [24] (microscopic level) and continues until the systems no longer fulfill the requirements for which these surfaces were designed, leading to failure (macroscopic level), see Figure 2.9. Changes in surface topography depend on operation conditions (load, temperature, velocity), material 
properties (wear rate decreases with increasing hardness) and lubricant characteristics.

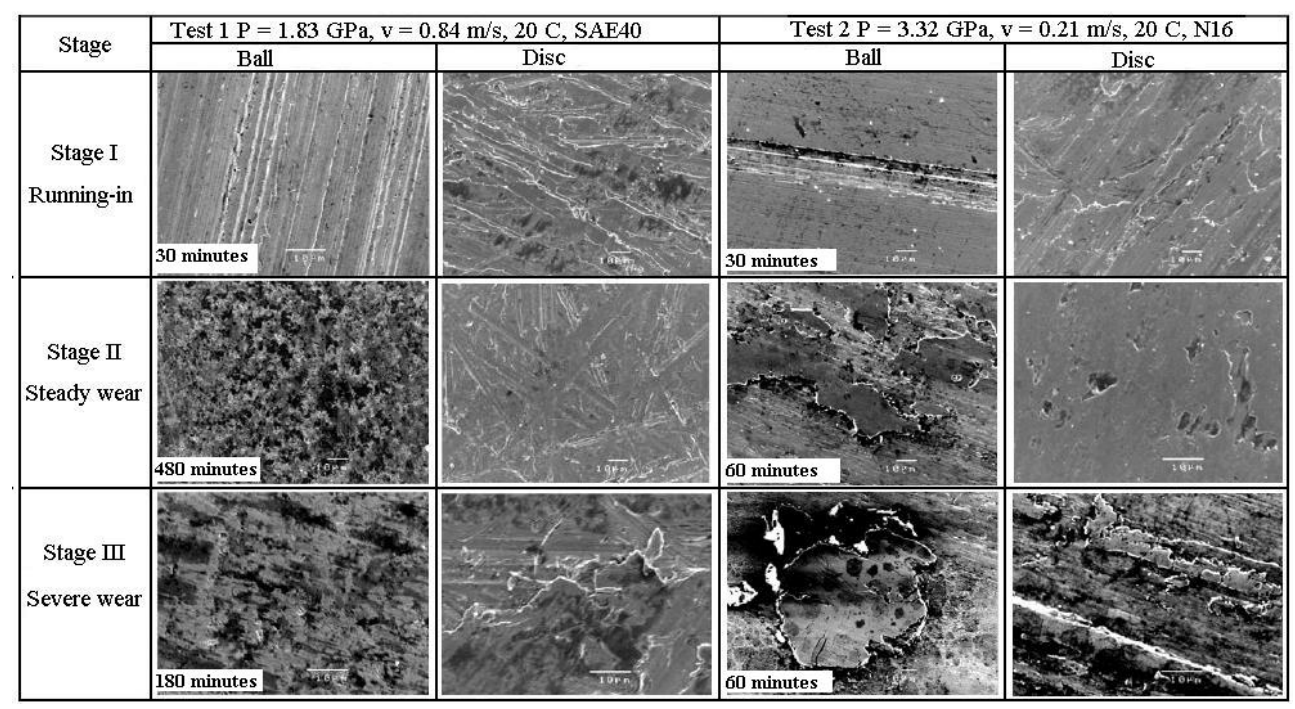

Figure 2.10 Surface topographies of the tested samples, reproduced from [25]

Figure 2.10 shows the evolution of the surface topography from two different friction tests, conducted on a ball-on-disc tester [25] using different types of lubricants (SAE 40 and N16). In test 2 (see Figure 2.10) wear is more pronounced (higher surface roughness and more wear particles generated throughout all wear stages) even when the sliding distance is less compared to test 1 . Wear is influenced as mentioned before by the test parameters: load (200 N - test 1 and 600 $\mathrm{N}$ - test 2) and lubricant viscosity (viscosity at $40{ }^{\circ} \mathrm{C}-144.6 \mathrm{~mm}^{2} / \mathrm{s}$ for test 1 and $15.3 \mathrm{~mm}^{2} / \mathrm{s}$ for test 2 ).

During lubricated sliding with high loads local deformations occur and lead to changes in microstructure of the subsurface zones (nano-crystalline layers) and material properties [26] affecting the values of the coefficient of friction and wear rates of rubbing surfaces.

In [27], subsurface deformations in lubricated aluminium alloy composites were investigated by focused ion beam microscopy (FIB). According to Figure 2.11 a, heavily deformed grains are formed and extend to $1-1.5 \mu \mathrm{m}$ below the surface being oriented parallel to the sliding direction.

In the second case (b) a large amount of plastic deformation occurs and is attributed to a different wear mechanism (wear track scratches formed by abrasive wear). 

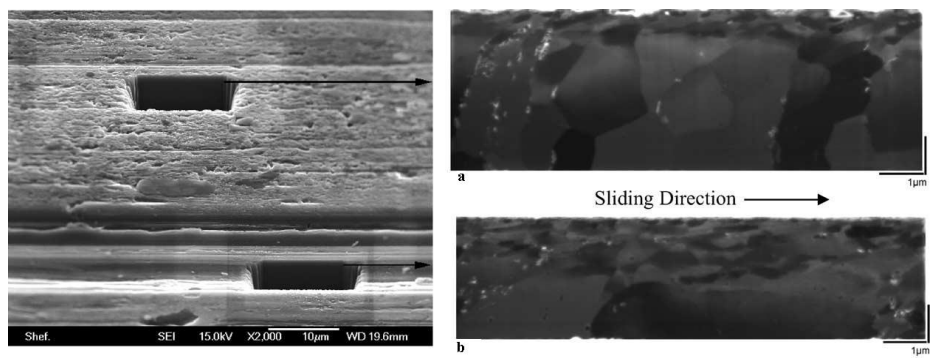

Figure 2.11 Subsurface deformations in a lubricated aluminium alloy composite (5056, after lubricated sliding at $630 \mathrm{~N}$ for $306 \mathrm{~km}$, reproduced from [27].

\subsubsection{Changes in contact geometry}

When two bodies are in contact, depending on surface geometry, three types of contact are possible (see Figure 2.13):

- line contact: cylindrical roller bearings, piston-ring cylinder liner;

- point contact: ball bearings, cam-follower contact;

- elliptical contact: bearings, rail-wheel contact, road-tire contact.

Due to friction between the system components, surface wear occurs and causes geometrical modification both on micro and macro level. Based on material properties (hardness), contact evolution due to wear for a sphere sliding against a flat is shown in Figure 2.12 [28].

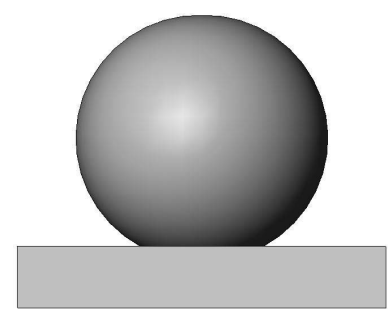

a) only sphere wears

$\mathrm{H}_{\text {ball }}<\mathrm{H}_{\text {flat }}$

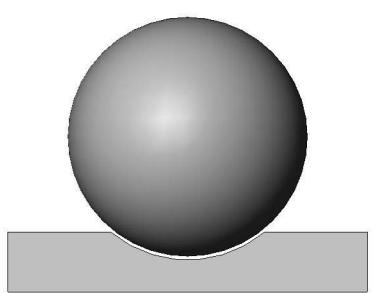

b) only flat wears

$\mathrm{H}_{\text {ball }}>\mathrm{H}_{\text {flat }}$

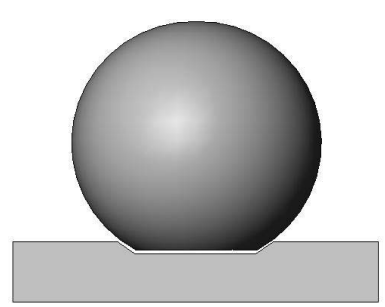

c) both sphere and flat wear

$\mathrm{H}_{\text {ball }} \approx \mathrm{H}_{\text {flat }}$

Figure 2.12 Change in contact configuration as a result of wear.

The evolution of the macro-geometry due to wear depends on, besides the operational parameters, the properties of the surfaces in contact. 

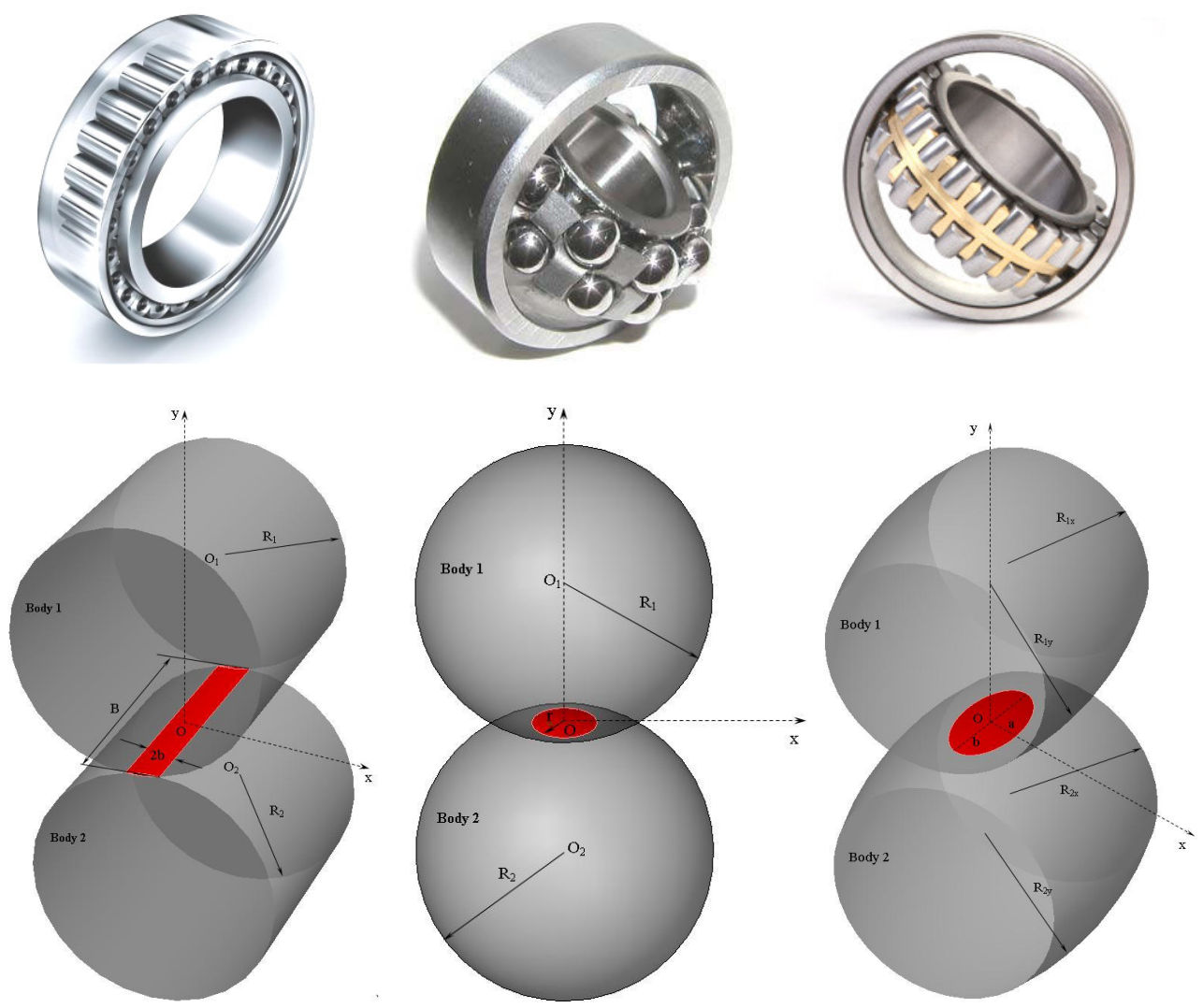

a) line contact

b) point contact

c) elliptical contact

Figure 2.13 Different types of contact geometry.

Considering the case in which only one of the bodies (pins) is worn, different profiles for dry and lubricated systems, see for instance [29, 30,31], are obtained after tests.

In the first case (Figure 2.14-a) flattening of the profile after wear tests is due to functioning of the system in the BL regime at low values for the velocity and high loads. Increasing the sliding velocity and reducing the load hydrodynamic effects in the contact occurs, which leads to formation of a wedge shape (see angle $\theta$ in Figure 2.14-b).

The worn geometry presented in the third case (Figure 2.14-c) differs from the other two geometries (new contact radius larger than the initial radius of the sphere) and is encountered in wear tests performed at low levels of speed and load. 


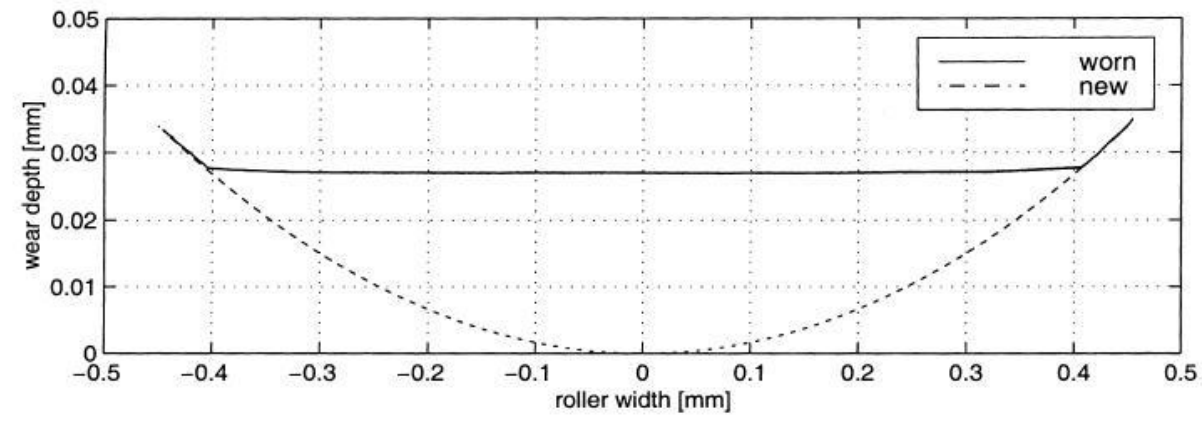

a) lubricated line contact and lubricated systems, see for instance [29], test parameters: $300 \mathrm{~N}, 0.14 \mathrm{~m} / \mathrm{s}, 30$ hours and lubricant: synthetic ester without any additives, $v_{40}=46 \mathrm{~mm}^{2} / \mathrm{s}$.

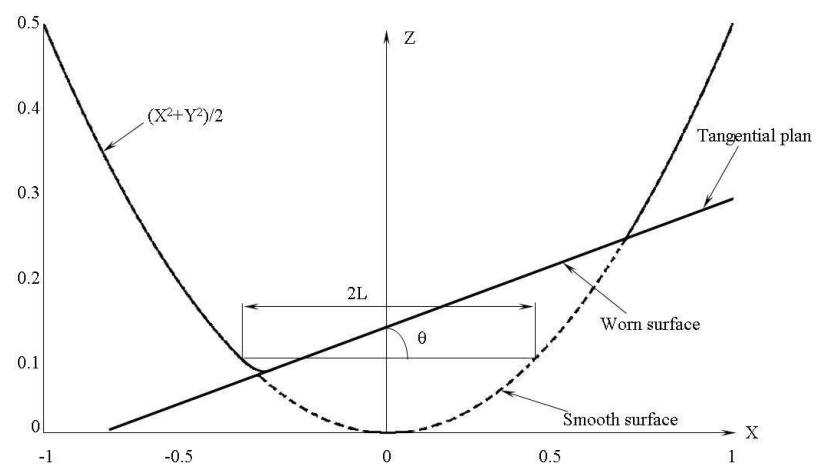

b) lubricated point contact [30], test parameters: $9.81 \mathrm{~N}, 1.57 \mathrm{~m} / \mathrm{s}$.

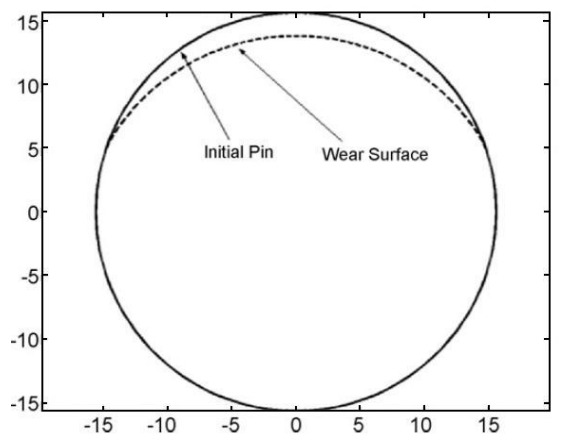

c) evolution of the geometry in pin joint contact after 408000 cycles from [31], test parameters: $\mathrm{k}=1 \cdot 10^{-5} \mathrm{~mm}^{3} / \mathrm{N} \cdot \mathrm{m}$.

Figure 2.14 Change in macro-geometry of lubricated contacts. 


\subsubsection{Changes in contact pressure}

The question arises: How does wear affect the contact pressure and which parameters are influenced by this?

In the previous section it has been shown that, depending on the operating conditions, machine elements change their macro-geometry in time having as consequence changes in operational parameters. Wear tests carried out for different materials in lubricated contacts indicate that by increasing the sliding distance between rubbing surfaces an increase in wear scars size is obtained which leads to a decrease of the contact pressure $\left(p=F_{N} / A_{\text {contact }}\right)$ [32]. Based on wear data from Figure 2.15 the authors conclude that the evolution of contact pressure depends on the material behaviour in interaction with the active products (additive package) from the lubricant (reactivity of steel with additives is more pronounced in the case of 52100 steel compared to ceramics $\mathrm{ZrO}_{2}$ and form protected layers whose properties result in a lower wear scar size respectively low wear rate).

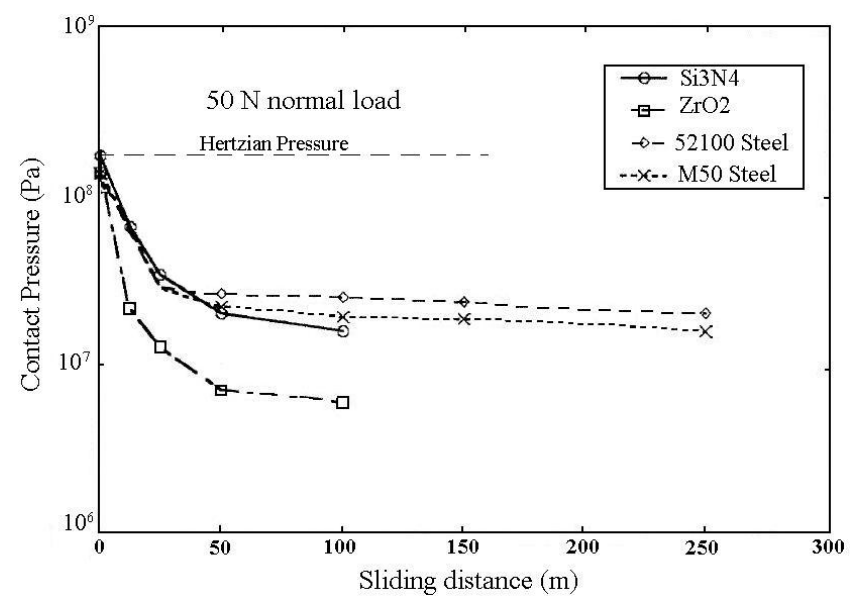

Figure 2.15 Evolution of the contact pressure in worn lubricated contacts $\left(F_{N}=\right.$ $50 \mathrm{~N}, \mathrm{~T}=23{ }^{\circ} \mathrm{C}$, humidity $=30-50 \%$, lubricant: polyolester based synthetic oil, pin and disc roughness $=0.08 \mu \mathrm{m}$, reproduced from [32] .

\subsubsection{Wear parameters: wear volume and wear rate}

Wear is expressed in the amount of volumetric material removed and can be measured by several methods with different accuracies: mass loss measurements, two dimensional (2D) and three dimensional (3D) topographical analysis. 
The first method is relatively quick and simple by measuring the mass of the samples before and after the wear tests, the amount of material removed can be calculated based on next equation:

$$
\mathrm{V}=\frac{\mathrm{m}_{\text {before }}-\mathrm{m}_{\text {after }}}{\rho}
$$

with: $\mathrm{V} \quad$ loss volume of material $\left[\mathrm{m}^{3}\right]$

$\mathrm{m}_{\text {before }} \quad$ mass of tested sample before wear test $[\mathrm{kg}]$

$\mathrm{m}_{\text {after }} \quad$ mass of tested sample after wear tests $[\mathrm{kg}]$

$\rho \quad$ material density $\left[\mathrm{kg} / \mathrm{m}^{3}\right]$

The accuracy of this method is low in the case of high wear-resistant materials due to the small amount of mass loss.

The second method, 2D is based on wear scar profile measurements. Wear volume calculations assume a flat worn surface (Figure 2.16-a). In the case of non-flat wear scars (Figure 2.16-b) the third method (3D) can be applied and involves profile measurements at multiple points of the tested samples. This method is accurate but is costly with respect to time [33].

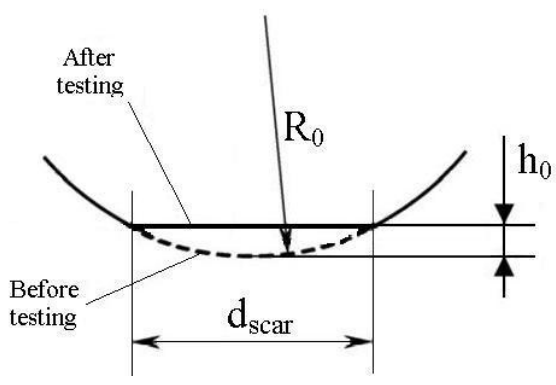

a) flat worn scars (dry contact)

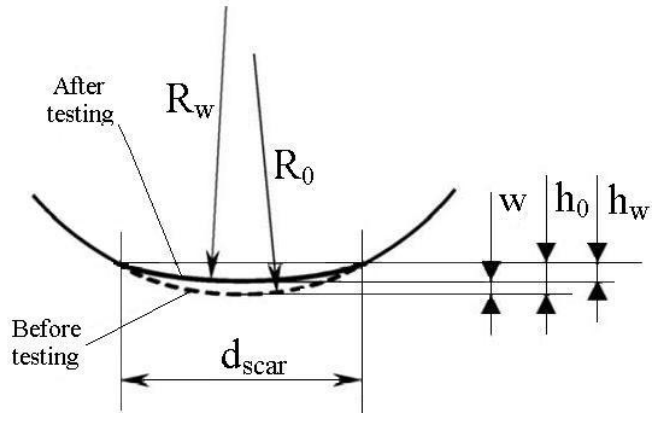

b) non-flat worn scars (lubricated contact)

Figure 2.16 Worn profile of tested samples [33].

In the case of the flat worn surfaces, the volume loss of material is calculated using the following equation (a point contact is considered):

$$
\mathrm{V}=\frac{\pi}{3} \cdot \mathrm{h}_{0}^{2} \cdot\left(3 \mathrm{R}_{0}-\mathrm{h}_{0}\right)
$$

For a worn surface whose geometry is shown in Figure 2.16-b the volume loss can be considered as: 


$$
\mathrm{V}=\frac{\pi}{3} \cdot\left[\mathrm{h}_{0}^{2} \cdot\left(3 \cdot \mathrm{R}_{0}-\mathrm{h}_{0}\right)-\mathrm{h}_{\mathrm{w}}^{2} \cdot\left(3 \cdot \mathrm{R}_{\mathrm{w}}-\mathrm{h}_{\mathrm{w}}\right)\right]
$$

where: $\mathrm{w} \quad$ wear depth, $\mathrm{w}=\mathrm{h}_{0}-\mathrm{h}_{\mathrm{w}}[\mathrm{m}]$

$\mathrm{R}_{0} \quad$ initial radius [m]

$\mathrm{R}_{\mathrm{w}} \quad$ new surface radius after wear test $\left(\mathrm{R}_{\mathrm{w}}>\mathrm{R}_{0}\right)[\mathrm{m}]$

$\mathrm{d}_{\text {scar }} \quad$ wear scar diameter $[\mathrm{m}]$

$\mathrm{h}_{0}, \mathrm{~h}_{\mathrm{w}}$ parameters of the worn profile (Figure 2.16-b) [m]

Table 2.1 presents loss volume formulas according to the mechanisms of wear present in the contact between two surfaces.

Table 2.1 Wear volume formulas [34].

\begin{tabular}{|c|c|c|}
\hline $\mathrm{Nr}$. & $\begin{array}{c}\text { Wear } \\
\text { mechanism }\end{array}$ & $\begin{array}{c}\text { Wear volume, } \\
\mathrm{V}\left[\mathrm{m}^{3}\right]\end{array}$ \\
\hline 1 & $\begin{array}{l}\text { Abrasive } \\
\text { wear }\end{array}$ & $\begin{array}{l}\qquad \mathrm{V}=\alpha \cdot \beta \cdot \frac{\mathrm{F}_{\mathrm{N}} \cdot \mathrm{s}}{\mathrm{H}} \\
\alpha \quad \text { the shape factor of the abrasive (asperity), } \alpha \sim 0.1 \\
\beta \quad \text { the degree of wear at one abrasive (asperity), } \beta \sim 0 \text { to } 0.1 \\
\mathrm{H} \text { material hardness }\end{array}$ \\
\hline 2 & $\begin{array}{l}\text { Adhesive } \\
\text { wear }\end{array}$ & $\begin{array}{l}\mathrm{V}=\mathrm{K} \cdot \frac{\mathrm{F}_{\mathrm{N}} \cdot \mathrm{s}}{\mathrm{H}} \\
\mathrm{K} \text { wear coefficient }\end{array}$ \\
\hline 3 & $\begin{array}{l}\text { Fatigue } \\
\text { wear }\end{array}$ & $\begin{array}{ll} & \mathrm{V}=\mathrm{K} \cdot \frac{\mathrm{F}_{\mathrm{N}} \cdot \mathrm{s}}{\mathrm{H}} \quad \mathrm{K}=\frac{9 \cdot \sqrt{3} \cdot \mathrm{r} \cdot \mu}{\mathrm{C}^{\mathrm{D}} \cdot \gamma_{\mathrm{t}}^{1-\mathrm{D}}} \\
\mathrm{r}, \mu, \gamma \mathrm{t} & \begin{array}{l}\text { coefficients } \\
\mathrm{C}\end{array} \\
\mathrm{D} & \begin{array}{l}\text { effective shear strain } \\
\text { experimental constant }\end{array}\end{array}$ \\
\hline 4 & $\begin{array}{l}\text { Corrosive } \\
\text { wear }\end{array}$ & $\begin{array}{ll}\quad \mathrm{V}=\mathrm{K} \cdot \frac{\mathrm{F}_{\mathrm{N}} \cdot \mathrm{s}}{\mathrm{H}} \quad \mathrm{K}=\mathrm{dA} \cdot \mathrm{e}^{\frac{-\frac{\mathrm{Q}}{\mathrm{R}_{\mathrm{g}} \cdot \mathrm{T}}}{\xi^{2} \cdot \rho^{2} \cdot \mathrm{v}}} \\
\mathrm{dA} & \text { Arrhenius constant } 10^{3}-10^{10} \\
\mathrm{Q} & \text { activation energy } \\
\mathrm{T} & \text { absolute temperature } \\
\rho & \text { density of oxide } \\
\mathrm{T} & \text { sliding velocity } \\
\mathrm{d} & \text { distance along which the wearing contact was made } \\
\mathrm{Rg} & \text { gas constant } \\
\mathrm{V} & \text { sliding distance } \\
\xi & \text { critical thickness of iron oxides }\end{array}$ \\
\hline
\end{tabular}




\subsection{Wear models}

Due to the complexity of wear no theoretical model is available which fully characterizes this phenomenon. Existing models given in the literature can be applied to a specific tribological application and are based on a possible wear mechanism (mechanical, chemical, physical and metallurgical action) that may occur between the rubbing surfaces.

The number of wear equations given is impressive; between 1957 and 1992 about 182 equations for erosion and sliding wear were proposed [35] which incorporate more than 100 variables and constants.

A wear model is defined as a listing, description or discussion of the variables that influence wear [36]. In [37] a model for predicting the rate of adhesive wear in a lubricated sliding contact was proposed. This model can be applied to a maximum sliding velocity of $0.1 \mathrm{~m} / \mathrm{s}$ and is based on the assumption that the load is supported by a lubricating film (influence of lubricant on wear process is given by a frictional film defect) and contacting asperities.

The volume of material removed from the contact is attributed to the contact load component (asperity contact) and is approximated by the next equation:

$$
\mathrm{V}=\mathrm{k}_{\mathrm{m}} \cdot \sqrt{1+3 \cdot \mu^{2}} \cdot \beta \cdot \frac{\mathrm{W}_{\mathrm{a}}}{\mathrm{P}_{\mathrm{m}}} \cdot s
$$

with: V wear volume

s sliding distance

$\mu \quad$ coefficient of friction

$\beta \quad$ fractional film defect, $\beta=0$ to 1

$\mathrm{k}_{\mathrm{m}} \quad$ characterizing the tendency of a sliding contact to wear by adhesion

$\mathrm{W}_{\mathrm{a}} \quad$ load component carried by asperities

$\mathrm{P}_{\mathrm{m}} \quad$ flow pressure of material

Reference [38] presents a wear model in lubricated contacts (partial EHL) in which abrasive wear is considered to be the main mechanism taking into account the following parameters: surface roughness profile, material hardness, operating condition (load, velocity) and visco-elastic characteristics of the solid. The wear model is given as:

$$
\frac{\mathrm{dV}}{\mathrm{ds}}=\mathrm{K} \cdot \frac{\mathrm{N} \cdot \mathrm{P}_{\mathrm{c}} \cdot \mathrm{S}_{\mathrm{m}} \cdot \alpha}{6 \cdot \sigma} \cdot \mathrm{H}^{*} \cdot \beta \cdot\left[3 \cdot \sigma \cdot \mathrm{e}^{\left(\frac{\mathrm{S}_{\mathrm{m}}}{4 \cdot \mathrm{v} \cdot \tau}\right)}-\mathrm{h}_{0}\right]
$$




$\begin{array}{cl}\text { where: } \mathrm{dV} / \mathrm{ds} & \text { wear rate }\left(\mathrm{m}^{3} / \mathrm{m}\right) \\ \mathrm{K} & \text { lubricated wear coefficient } \\ \mathrm{N} & \text { parameter } \mathrm{N}=1 / \mathrm{S}_{\mathrm{m}}[1 / \mathrm{m}] \\ \sigma & \text { composite surface roughness }[\mathrm{m}] \\ \beta & \text { exponent sign } \\ \alpha & \text { height modification coefficient } \\ \mathrm{V} & \text { sliding velocity }[\mathrm{m} / \mathrm{s}] \\ \tau & \text { delay time }[\mathrm{s}] \\ \mathrm{h}_{0} & \text { average film thickness }[\mathrm{m}] \\ \mathrm{H}^{*} & \text { hardness ratio, } \mathrm{H}^{*}=\mathrm{H}_{\text {hard surface }} / \mathrm{H}_{\text {soft surface }}[-] \\ \mathrm{P}_{\mathrm{c}} & \text { probability of the asperity contact } \\ \mathrm{S}_{\mathrm{m}} & \text { average asperity wavelength }[\mathrm{m}]\end{array}$

Another sliding wear model for partial EHL is presented in [39] in which two wear mechanisms are assumed to occur in the contact: 1) thermal desorption (at low asperity contact temperature) and 2) oxidative (at elevated asperity contact temperature) wear mechanism.

The appearance of the two mechanisms is influenced by the contact temperature at asperity level. If the contact temperature exceeds $200{ }^{\circ} \mathrm{C}$, then the physisorption may no longer be valid and an oxide film can be formed at the collision point between the asperities, possibly by detaching from the surface and forming oxidative wear particles

The equations which describe the wear model as a function of the asperity temperature $T_{i}$ are:

$$
\frac{\mathrm{V}_{\mathrm{i}}}{\mathrm{s}}=\mathrm{k}_{\mathrm{m}} \cdot \mathrm{A}_{\mathrm{n}} \cdot\left\{1-\mathrm{e}^{\left[-\frac{\mathrm{X}}{\mathrm{U} \cdot \mathrm{t}_{0}} \cdot \mathrm{e}^{\frac{\mathrm{E}}{\mathrm{R} \cdot \mathrm{T}_{\mathrm{i}}}}\right]}\right\} \cdot\left(\frac{\mathrm{A}_{\mathrm{ci}}}{\mathrm{A}_{\mathrm{n}}}\right), \text { for } \mathrm{T}_{\mathrm{i}}<200{ }^{\circ} \mathrm{C}
$$

Function of $T_{\mathrm{i}}$ values, wear is defined by a general equation:

$$
\frac{V_{i}}{s}=\frac{A_{0} \cdot A_{n}}{C_{x} \cdot U} \cdot e^{\left(-\frac{Q_{0}}{R \cdot T_{i}}\right)} \cdot\left(\frac{A_{c i}}{A_{n}}\right)
$$

with: V wear volume loss $\left[\mathrm{m}^{3}\right]$

$\mathrm{s} \quad$ sliding distance $[\mathrm{m}]$

$\mathrm{R}$ molar gas constant 
$\mathrm{v} \quad$ sliding velocity $[\mathrm{m} / \mathrm{s}]$

$\mathrm{A}_{\mathrm{ci}}$ local asperity contact area $\left[\mathrm{m}^{2}\right]$

$\mathrm{A}_{\mathrm{n}}$ nominal contact area $\left[\mathrm{m}^{2}\right]$

$\mathrm{Ti} \quad$ local asperity contact temperature $[\mathrm{K}]$

$\mathrm{Q}_{0} \quad$ activation energy for oxidation [J/mole]

$\mathrm{k}_{\mathrm{m}} \quad$ wear coefficient parameter specific to the contacting asperities [-]

$\mathrm{C}_{\mathrm{x}} \quad$ oxide constant [-] and $\mathrm{C}_{\mathrm{x}}=\mathrm{C}_{3 / 4}$ for $200{ }^{\circ} \mathrm{C} \leq \mathrm{T}_{\mathrm{i}}<350{ }^{\circ} \mathrm{C}$

$\mathrm{C}_{\mathrm{x}}=\mathrm{C}_{2 / 3}$ for $350{ }^{\circ} \mathrm{C} \leq \mathrm{T}_{\mathrm{i}}<570{ }^{\circ} \mathrm{C}$

$\mathrm{C}_{\mathrm{x}}=\mathrm{C}_{1 / 2}$ for $\mathrm{T}_{\mathrm{i}} \geq 570{ }^{\circ} \mathrm{C}$

\subsection{Summary}

This chapter presented a review of the literature on wear in lubricated systems. A discussion followed the introduction, which looked at wear classification and methods used to evaluate this phenomenon. Sections 2.2.2.2 and 2.2.2.4 presented the macro-geometrical changes in lubricated contact and the amount of material removed due to wear on the basis of the wear tests conducted in the literature. The last section of this chapter showed descriptive wear models for the different wear mechanisms: adhesive, abrasive and corrosive wear. These models, however, cannot be used within the scope of this research.

To study the effect of wear on friction the general observed geometry for highly loaded concentrated contacts as presented in Figure 2.14-a is adopted in this thesis.

The main conclusion is that there is no model available which predicts wear as a function of the operational condition/parameters. Therefore a $\mathrm{k}$ value will be used to describe the change in macro-geometry as a function of the operational conditions and as a result the effect of wear on friction.

\subsection{References}

[1] Sethuramiah, A., "Lubricated wear, science and technology", Tribology Series, Vol. 42, Elsevier, 2003, p. 116.

[2] Bhushan, B. "Modern Tribology Handbook", Vol. 1, CRC Press LLC, 2001, pp. 275-321.

[3] Kato, K., "Wear in boundary or mixed lubrication regime", Boundary and Mixed Lubrication: Science and Applications (Dowson, D. et al.), Elsevier Science B.V., pp. 3-7.

[4] Stachowiak, G.W. "Wear - Materials, mechanisms and practice", John Wiley \& Sons Ltd, UK, 2005, p. 42. 
[5] Lim, S.C., "Recent developments in wear mechanism maps", Tribology international, Vol. 31, Nos 1-3, 1998, pp. 87-97.

[6] So, H. and Hu, C.C., "Effects of friction modifiers on wear mechanism of some steels under boundary lubrication conditions", Bench testing of industrial fluid lubrication and wear properties used in machinery applications (Totten, G.E. et all), ASTM Stock Number, STP 1404, 2001, pp. 125-139.

[7] de Gee, A.W.J. and Rowe, G.W. "Friction, Wear and Lubrication Tribology Glossary", OECD, Paris, 1969. HMSO.

[8] Kajdas, C., Harvey, S.S.K and Wilusz, E., "Encyclopedia of tribology", Vol. 15, Elsevier, 1990, pp. 2-5.

[9] Society of tribologists and lubrication engineers, Lubelearn, Education Courses, Basics of wear.

[10] Bayer, R.G., "Mechanical wear prediction and prevention" Marcel Dekker INC, New York, 1994, p. 36.

[11] Jones, M.H. and Scott, D. "Industrial tribology - the practical aspect of friction, lubrication and wear", Tribology Series, Vol. 8, Elsevier, 1983, pp. 242.

[12] Neale, M.V., "The Tribology handbook - second edition", ButterworthHeinemann, Oxford, 1995, p. E.1.

[13] Buckley, D.H., "Tribological properties of surfaces", Thin Solid Films, Vol. 53, 1978, pp. 271-283.

[14] Bec, S., Tonck, A., Georges, J.M., Coy, R.C., Bell, J. C. and Roper, G. W., "Relationship between mechanical properties and structures of zinc dithiophosphate anti-wear films", Mathematical, Physical and Engineering Sciences, Vol. 455, No. 1992, pp. 4181-4203.

[15] Thomas, T.R., "Rough surfaces - second edition", Imperial College Press, London, 1999.

[16] Sundh, J., and Satra, U.S., "Influence of surface topography and surface modifications on seizure initiation in lean lubricated sliding contacts", Wear, Vol. 262, 2007, pp. 986-995.

[17] Sedlacek, M., Podgornik, B. and Vizintin, J., "Influence of surface preparation on roughness parameters, friction and wear", Wear, Vol. 266, 2009, pp. 485-486.

[18] Jisheng, E. "Effect of thermochemical treatments on the sliding wear mechanism of steels under boundary lubrication" Tribology Transactions, Vol. 42,1999, pp. 626-632.

[19] Jisheng, E. and Gawne, D.T., "Wear characteristics of plasma-nitrited CrMo steel under mixed and boundary lubricated conditions", Journal of Material Science, Vol. 32, 1997, pp. 913-920. 
[20] Liskiewicz, T., Mathia, T. Fouvry, S. and Neville A., "Systematic approach for morphological analysis of worn surfaces", Tribotest, Vol.13, 2007, pp. 139-150.

[21] Schipper, D.J., "Transition in the lubrication of concentrated contact", $\mathrm{PhD}$ thesis, University of Twente, Enschede, The Netherlands, 1988.

[22] Dienwiebel, M., and Pohlmann, K. "Nanoscale evolution of sliding Metal Surfaces during running-in", Tribology Letters, Vol. 27, 2007, pp. 255-260.

[23] Jamari, "Running-in of rolling contacts", $\mathrm{PhD}$ thesis, University of Twente, The Netherlands, 2005.

[24] Tasan,Y.C., de Rooij, M.B. and Schipper, D.J., "Changes in microgeometry of a rolling contact", Tribology International, Vol. 40, 2007, pp. 672-679.

[25] Yuan, C.Q., Peng, Z., Yan, X.P., Zhou, X.C., "Surface roughness evolution in sliding wear process", Wear, Vol. 265, 2008, pp. 341-348.

[26] Hughes, D.A., Dawson, D.B., Korellis, J.S. and Weingarten, L.I., "Near surface microstructures developing under large sliding loads", Journal of Materials Engineering and Performance, Vol. 3, 1994, pp. 459-475.

[27] Walker, J.C., Rainforth, W.M. and Jones, H. "Lubricated sliding wear behavior of aluminium alloy composites", Wear, Vol. 256, 2005, pp. 577589.

[28] ASTM G 99 - 95a: Standard test method for wear testing with a pin-ondisc apparatus.

[29] Oqvist, M., "Numerical simulations of mild wear using updated geometry with different step size approaches", Wear, Vol. 249, 2001, pp. 6-11.

[30] Wong, P.L., Huang, P., Wang, W. and Zhang, Z., "Effect of geometry change of rough point contact due to lubricated sliding wear on lubrication", Tribology Letters, Vol. 5, 1998, pp. 265-274.

[31] Mukras, S., Kim, N.H., Sawyer, W.G., Jackson, D.B. and Berquist, W., "Numerical integration schemes and parallel computation for wear prediction using finite element method", Wear, Vol. 266, 2009, pp. 822831.

[32] Ajayi, O.O. and Erck, R.A. "Variation of nominal contact pressure with time during sliding wear", Technical Report, DE2002-799783, Energy Technology Division Argonne National Laboratory, 2001.

[33] Qu, J. and Truhan, J.J., "An efficient method for accurately determining wear volume of sliders with non-flat wear scars and compound curvatures", Wear, Vol. 261, 2006, pp. 848-855.

[34] Kato, K., "Classification of wear mechanisms/models", Journal Engineering Tribology, Vol. 216, 2002, pp. 349-355. 
[35] Meng, H.C., "Evaluation and categorization of wear models", $\mathrm{PhD}$ thesis, University of Michigan, U.S.A., 1994.

[36] Meng, H.C. and Ludema, K.C., "Wear models and predictive equations: their form and content", Wear, Vol. 181-183, 1995, pp. 443-457.

[37] Stolarski, T.A., "A system for wear prediction in lubricated sliding contacts", Lubrication Science, Vol. 8-4, 1996, pp. 315-351.

[38] Zou, Q., Huang, P. and When S., "Abrasive wear model for lubricated sliding contacts", Wear, Vol. 196, 1996, pp. 72-76.

[39] Wu, S. and Cheng, H.S., "A sliding wear model for partial-EHL contacts", Journal of Tribology, Vol. 113, 1991, pp. 134-141. 


\section{Chapter 3 Film thickness in worn lubricated concentrated contacts}

\subsection{Introduction}

In the previous chapter, influences of different operational parameters on contact geometry evolution were discussed (velocity, load, time, material and lubricant properties). Tests conducted on different tribometers show that the contact geometry starts to change at microscopic level and continues until system components no longer fulfill the functional specifications for which they have been designed (macroscopic level). The changes in contact geometry may lead to modification in operational parameters like: contact pressure, contact temperature, lubrication regime, etc., so the system no longer operates at its optimum.

In this chapter the influence of wear on the minimum film thickness in worn lubricated concentrated contacts is investigated based on changes in the macro contact geometry.

\subsection{Minimum separation in worn lubricated contacts}

The component's geometry evolves in time: at first it is Hertzian (see Appendix A) followed as a function of the operational conditions by stages that allow a system to operate within normal limits and finally to reach the final stage: failure. Depending on the operational parameters lubricated systems operate in different lubrication regimes: BL, ML and (E)HL. In the case of systems which operate in the $\mathrm{BL}$ regime a high friction value between the components is present. In time wear occurs and leads to a modification of the microscopic and macroscopic geometry of the components.

Can these changes in geometry affect the operational regime of a lubricated system?

The answer to this question is found by calculating the relation between operational key parameters of systems taking wear into account. For each concentrated contact a worn contact geometry is proposed based on experimental data from "wear" tests performed on a pin-on-disc tribometer. 


\subsubsection{Geometry of a worn line contact}

Experimental data from Chapter 5 and literature (chapter 2) show the evolution of pin profile geometries in sliding direction due to wear.

All pin profiles after wear tests show a new surface curvature which is larger than the original pin curvature $\left(\mathrm{R}_{\mathrm{w}}>\mathrm{R}\right)$ and parameters that defined the worn profiles are according to [1] and shown in Figure 3.1.

a) unloaded

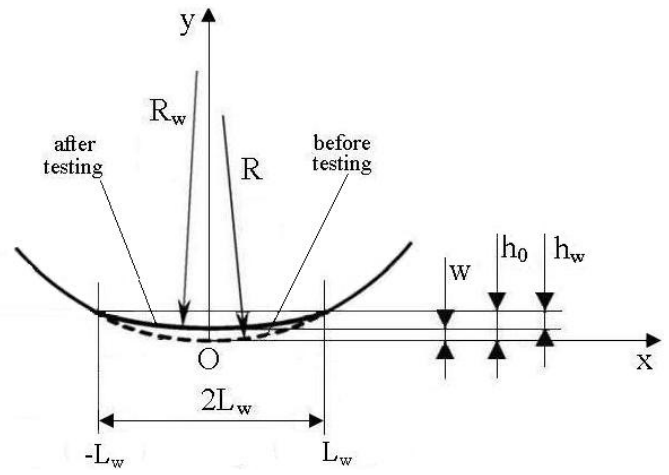

b) loaded

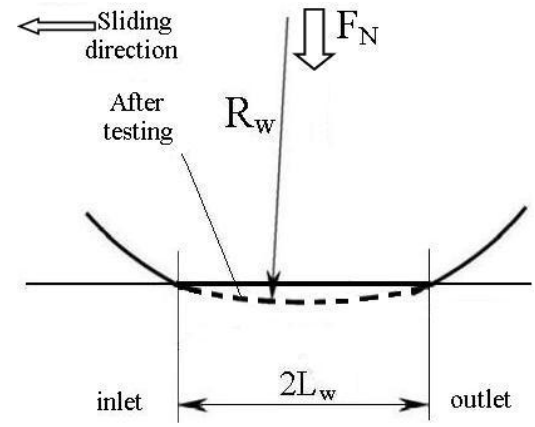

Figure 3.1 View of the worn pin profile.

where: $R$ is the initial pin radius, $R_{w}$ is the worn radius, $w$ is wear depth and $2 \mathrm{~L}_{w}$ is the contact width.

To determine the evolution of pin profile geometry due to wear a general equation is used:

$$
f(x)=\left\{\begin{array}{l}
-\sqrt{R^{2}-x^{2}}+\left(\sqrt{R_{w}^{2}-L_{w}^{2}}-\sqrt{R^{2}-L_{w}^{2}}\right) \text { if } x \in\left(-L_{w}, L_{w}\right) \\
\text { otherwise }-\sqrt{R^{2}-x^{2}}
\end{array}\right.
$$

Using parameters from Table 3.1 of a wear test, measured and predicted profiles are shown in Figure 3.2. Due to small differences between profiles it can be concluded that equation (3.1) can be used to describe the profile geometry of a worn line contact. 
Table 3.1 Worn line profile parameters.

\begin{tabular}{|c|c|c|c|c|c|}
\hline $\begin{array}{c}\text { Time } \\
{[\mathrm{h}]}\end{array}$ & $\begin{array}{c}\text { Wear scar, } \\
2 \mathrm{~L}_{\mathrm{w}}[\mu \mathrm{m}]\end{array}$ & $\begin{array}{c}\text { Wear depth, } \\
\mathrm{w}[\mu \mathrm{m}]\end{array}$ & $\begin{array}{c}\text { Worn radius, } \\
\mathrm{R}_{\mathrm{w}}[\mathrm{mm}]\end{array}$ & $\begin{array}{c}\text { Contact pressure, } \\
\mathrm{p}_{\text {mean }}[\mathrm{MPa}]\end{array}$ & $\begin{array}{c}\text { Wear rate, } \\
\mathrm{k}\left[\mathrm{mm}^{3} / \mathrm{Nm}\right]\end{array}$ \\
\hline 0 & 12.8 & 0 & 2 & 146.3 & - \\
\hline 4 & 180 & 2.1 & 7.4 & 10.4 & $7.05 \cdot 10^{-6}$ \\
\hline 8 & 220 & 3.1 & 9.3 & 8.5 & $1.76 \cdot 10^{-6}$ \\
\hline 12 & 270 & 4.5 & 14 & 6.9 & $1.96 \cdot 10^{-6}$ \\
\hline
\end{tabular}

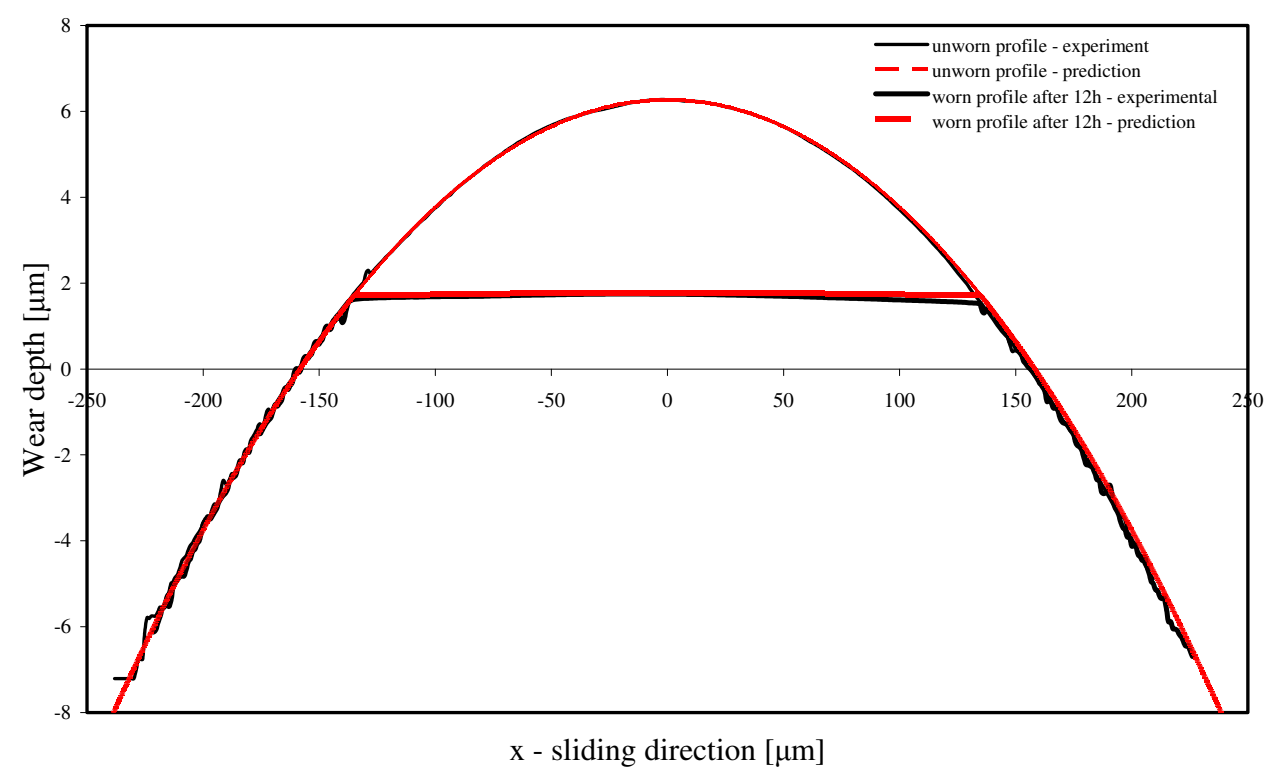

Figure 3.2 Comparison between measured profile and predicted profiles of a worn line contact.

To find the minimum separation in a worn line contact the geometry of the worn profile presented in Figure 3.3 is used. In a lubricated contact three regions are distinguished: inlet, contact and outlet region. The geometry of the inlet region plays an important role in pressure generation, and as a result the minimum separation between the opposing surfaces.

The equation of the oil film thickness in the inlet between a flat and a worn cylinder is:

$$
\mathrm{h}=\mathrm{h}_{\min }+\mathrm{h}_{\mathrm{g}} \text {, where } \mathrm{h}_{\mathrm{g}}=\mathrm{h}^{\prime}-\mathrm{w}
$$




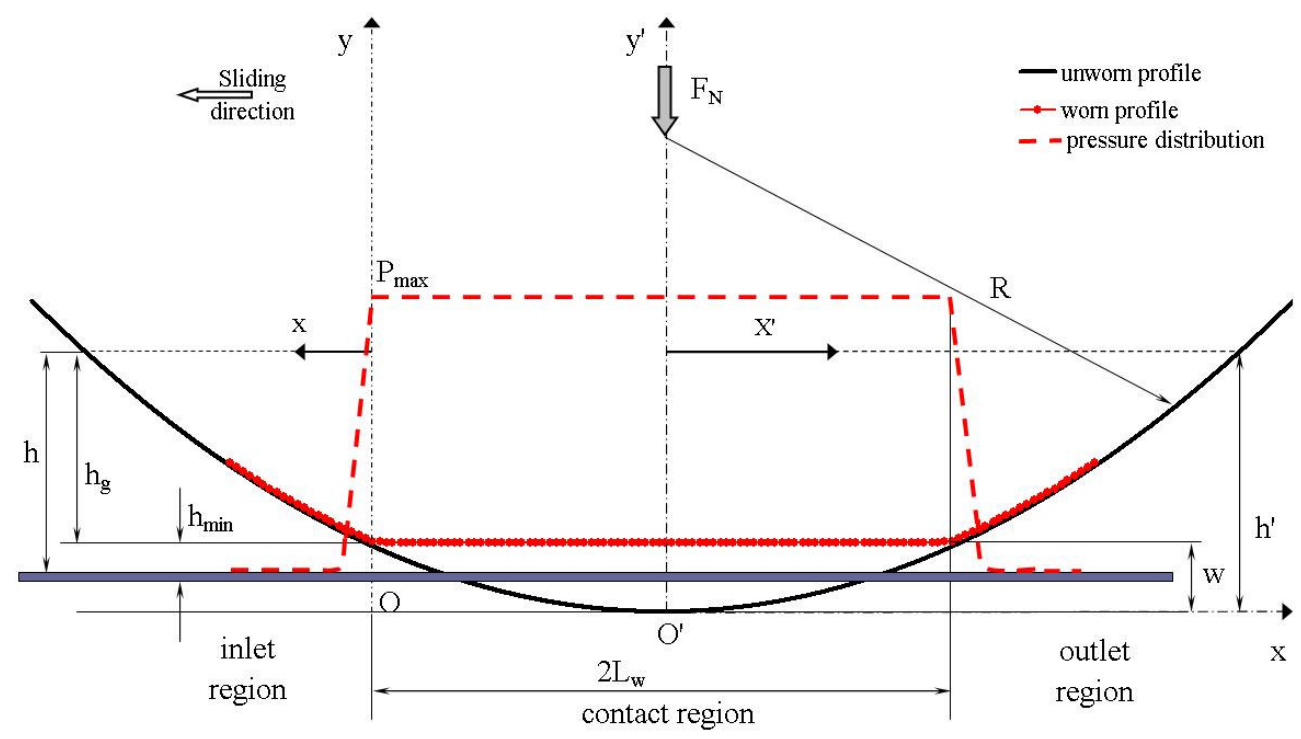

Figure 3.3 Worn lubricated line contact geometry and corresponding pressure distribution.

in which: $h$, h' are the total film thickness specific to the coordinate system (xoy respectively x'o'y'), $h_{g}$ - film thickness given by the inlet geometry, $h_{\min }$ is the minimum film thickness, $w$ is wear depth, $\mathrm{R}$ radius of the cylinder, $\mathrm{p}_{\max }$ is the maximum contact pressure, $F_{N}$ is the load and the size of the wear scar width is equal to $2 \mathrm{~L}_{\mathrm{w}}$.

\subsubsection{Minimum film thickness calculations}

In the case of lubricated contacts the Reynolds equation is used to describe the relation between the pressure distribution and film shape as a function of the viscosity and the velocity [2].

$$
\frac{\partial}{\partial x}\left(h^{3} \frac{\partial p}{\partial x}\right)+\frac{\partial}{\partial y}\left(h^{3} \frac{\partial p}{\partial y}\right)=6 \cdot \eta \cdot v \frac{\partial h}{\partial x}
$$

$\mathrm{v} \quad$ sum of surfaces velocity

$\mathrm{x}, \mathrm{y}$ spatial Cartesian coordinates $\mathrm{p}$ pressure $\eta$ lubricant viscosity

$\mathrm{h}$ film thickness 
The most significant property of lubricants is the viscosity which is dependent on pressure [3], temperature [4] and shear rate [5].

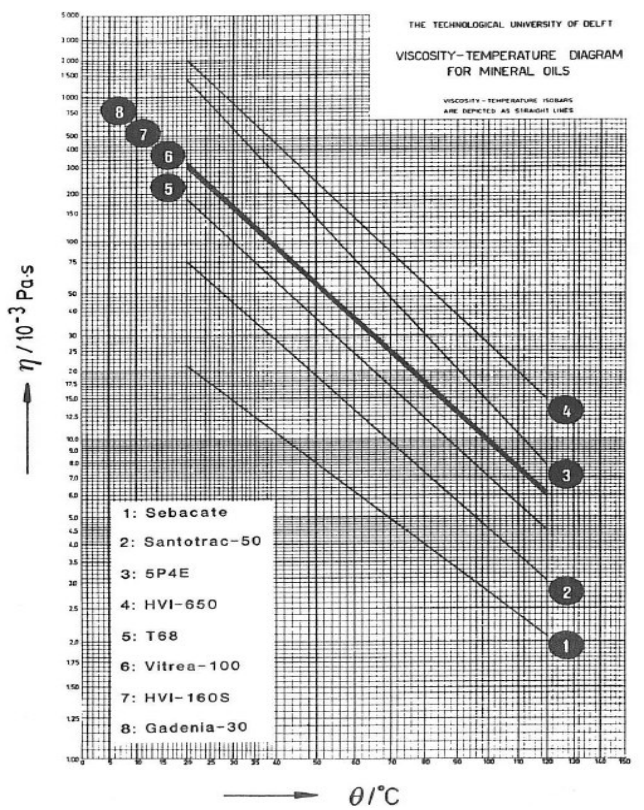

Figure 3.4 Viscosity-temperature diagram reproduced from [4].

According to [6] the minimum film thickness in an EHL line contact can be estimated accurately by using a survey diagram in which four asymptotic solutions are presented for the rigid-isoviscous RI, rigid-piezoviscous RP, elasto-isoviscous EI and elasto-piezoviscous EP regime.

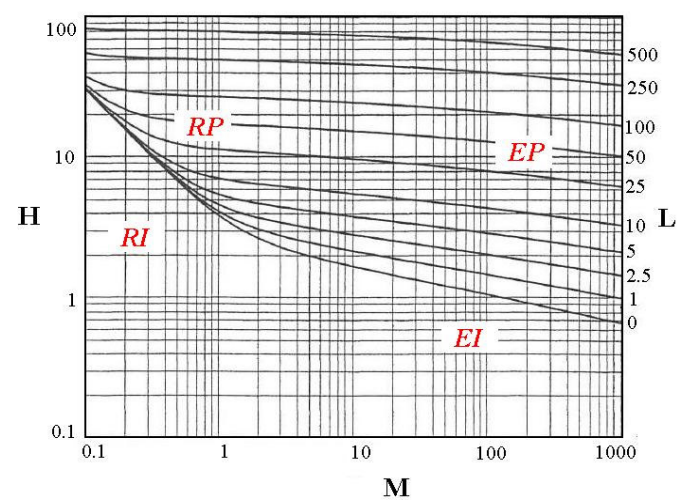

Figure 3.5 Survey diagram for the EHL at line contact [6]. 
To determine the minimum film thickness for worn lubricated line contacts some assumptions are made:

a) the surfaces are perfectly smooth;

b) the lubricant acts as a Newtonian fluid and the lubricant flow is only in sliding direction ( $\mathrm{x}$ direction);

c) due to macroscopic wear, the contact pressure decreases and the rubbing surfaces behave as rigid (RI regime).

In the case of isoviscous lubricant behaviour the viscosity is considered to be constant i.e.:

$$
\eta=\eta_{0}
$$

in which $\eta_{0}$ is the viscosity at ambient pressure [Pa·s]

Considering the above assumptions, equation (3.3) results in:

$$
\frac{\partial}{\partial x}\left(h^{3} \frac{\partial p}{\partial x}\right)=6 \eta_{0} v \frac{\partial h}{\partial x}
$$

Occurrence of wear during operation leads to changes in component geometry and the film profile in the inlet region is given by:

$$
\mathrm{h}=\mathrm{h}_{\min }+\mathrm{R}-\sqrt{\mathrm{R}^{2}-\left(\mathrm{x}+\mathrm{L}_{\mathrm{w}}\right)^{2}}-\mathrm{w}
$$

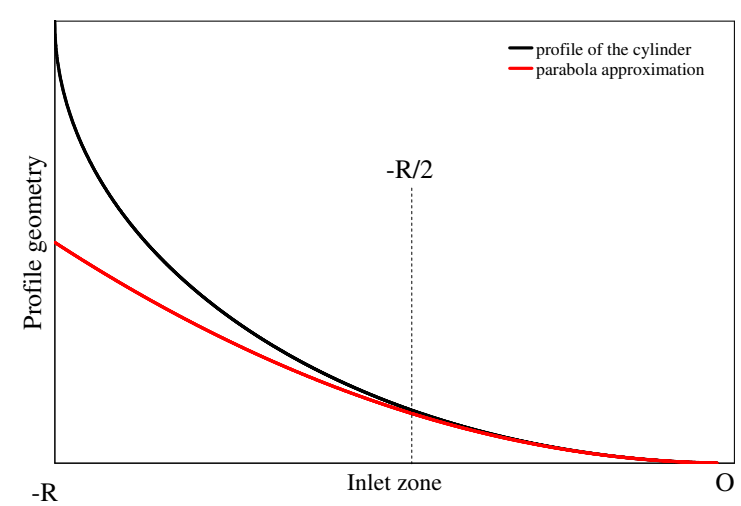

Figure 3.6 Approximation of the cylinder profile by a parabola. 
For calculations, the inlet shape $\left(\mathrm{R}-\sqrt{\mathrm{R}^{2}-\left(\mathrm{x}+\mathrm{L}_{w}\right)^{2}}\right)$ is approximated by a parabola $\left(\left(x+L_{w}\right)^{2} / 2 R\right)$ which is valid only for the cases when $L_{w}<R / 2$ see Figure 3.6. The film in the inlet zone becomes:

$$
\mathrm{h}=\mathrm{a}+\mathrm{bX} \mathrm{X}^{2} \text {, where } \mathrm{a}=\mathrm{h}_{\min }-\frac{\mathrm{L}_{\mathrm{w}}^{2}}{2 \mathrm{R}}, \mathrm{b}=\frac{1}{2 \mathrm{R}} \text { and } \mathrm{X}=\mathrm{x}+\mathrm{L}_{\mathrm{w}}
$$

The minimum film thickness calculations in worn lubricated point contacts follow the classical solution from EHL theory described in [7]. The general solution of (3.5) is:

$$
\frac{\mathrm{dp}}{\mathrm{dx}}=6 \eta_{0} \mathrm{v} \frac{\mathrm{h}-\mathrm{h}_{\mathrm{r}}}{\mathrm{h}^{3}}
$$

where $h_{r}$ is a constant whose value is found from the condition that the flow in inlet region is the same as the flow in contact region and at $\mathrm{x}=0, \mathrm{dp} / \mathrm{dx}=0$.

$$
\mathrm{h}_{\mathrm{r}}=\mathrm{h}_{\min }
$$

The pressure distribution over inlet region is found by integrating relation (3.8):

$$
\mathrm{p}=6 \eta_{0} \mathrm{v}\left[-\frac{\mathrm{h}_{\min }}{4 \mathrm{a}} \frac{\mathrm{X}}{\left.(\mathrm{a}+\mathrm{bX})^{2}\right)^{2}}+\left(\frac{1}{2 \mathrm{a}}-\frac{3 \mathrm{~h}_{\min }}{8 \mathrm{a}^{2}}\right)\left(\frac{\mathrm{X}}{\mathrm{a}+\mathrm{bX} \mathrm{X}^{2}}+\frac{1}{\sqrt{\mathrm{ab}}} \operatorname{atan}\left(\frac{\mathrm{bX}}{\sqrt{\mathrm{ab}}}\right)\right)\right]+\mathrm{C}
$$

By considering the limit condition $\mathrm{p}(-\infty)=0$ the integration constant $\mathrm{C}$ is found and the pressure distribution over inlet zone is represented by:

$$
p=6 \eta_{0} v\left\{-\frac{h_{\text {min }}}{4 a} \frac{X}{\left(a+b X^{2}\right)^{2}}+\left(\frac{1}{2 a}-\frac{3 h_{\min }}{8 a^{2}}\right)\left[\begin{array}{l}
\frac{X}{a+b X^{2}}+ \\
+\frac{1}{\sqrt{a b}}\left(\operatorname{atan}\left(\frac{b X}{\sqrt{a b}}\right)+\frac{\pi}{2}\right)
\end{array}\right]\right\}
$$

Applying the second limit condition $\mathrm{p}\left(\mathrm{L}_{\mathrm{w}}\right)=\mathrm{p}_{\max }$, the maximum pressure in the inlet region is found: 


$$
\mathrm{p}_{\max }=\frac{3}{4} \eta_{0} \mathrm{v} \frac{1}{\mathrm{~h}_{\min }^{\frac{3}{2}}}\left(-\frac{\mathrm{L}_{\mathrm{w}}}{\mathrm{h}_{\min }^{\frac{1}{2}}}+\frac{\pi}{\sqrt{2}} \cdot \sqrt{\mathrm{R}}\right)
$$

The load carried by the contact is the integral over the whole pressure field:

$$
\frac{\mathrm{F}_{\mathrm{N}}}{\mathrm{B}}=\int_{-\infty}^{0} \mathrm{pdx}+2 \mathrm{~L}_{\mathrm{w}} \mathrm{p}_{\max }+\int_{2 \mathrm{~L}_{\mathrm{w}}}^{\infty} \mathrm{pdx}
$$

Further, the minimum value of the film thickness between surfaces in the case of rigid isoviscous behaviour is found from the force equilibrium equation (3.13) in which the contribution of the inlet and outlet pressure to $F_{N}$ is considered to be insignificant compared to the contact pressure (pressure in the inlet pressure is generated near to the point $\mathrm{O}$, see Figure 3.3), resulting in:

$$
\mathrm{h}_{\operatorname{minRI}}=\frac{1}{12} \frac{\left[108 \delta_{\mathrm{RI}}^{2}+12\left(81 \delta_{\mathrm{RI}}^{4}-768 \beta_{\mathrm{RI}}^{3}\right)^{\frac{1}{2}}\right]^{\frac{2}{3}}+48 \beta_{\mathrm{RI}}}{\left[108 \delta_{\mathrm{RI}}^{2}+12\left(81 \delta_{\mathrm{RI}}^{4}-768 \beta_{\mathrm{RI}}^{3}\right)^{\frac{1}{2}}\right]^{\frac{1}{3}}}
$$

where: $\delta_{\mathrm{RI}}=-\frac{3 \pi}{4 \sqrt{2}} \frac{\eta_{0} \mathrm{v} \sqrt{\mathrm{R}}}{\mathrm{p}_{\text {mean }}} \quad$ and $\quad \beta_{\mathrm{RI}}=\frac{3}{4} \frac{\eta_{0} \mathrm{vL}_{\mathrm{w}}}{\mathrm{p}_{\text {mean }}}$

In worn contacts it is assumed that due to low contact pressure the maximum contact pressure is given by the mean contact pressure, $p_{\text {mean }}=\frac{F_{N}}{2 \mathrm{BL}_{\mathrm{w}}}$. When wear does not occur in the contacts, the minimum film thickness can be calculated with equation (3.15) relation which is close to rigid isoviscous calculations presented in [8]:

$$
\mathrm{h}_{\text {minRI }}=1.40539\left(\frac{\eta_{0} \mathrm{v}}{\mathrm{p}_{\text {mean }}}\right)^{\frac{2}{3}} \mathrm{R}^{\frac{1}{3}}
$$


Equations for the minimum lubricant film thickness $\left(\mathrm{h}_{\min }\right)$ for line contacts for the EHL regime can be found in [2] and [6]. Rewriting these equations one can express the film thickness in general by:

$$
h=c \cdot f(\alpha, G) \cdot\left(\frac{\eta \cdot v}{p_{\text {mean }}}\right)^{n}
$$

In which $c$ is a constant, $f(\alpha, G)$ is a function which depends on contact geometry (G) and pressure-viscosity coefficient $(\alpha), \mathrm{n}$ is a power coefficient $(\sim 0.7), \eta$ is dynamic inlet viscosity, $v$ is velocity, and $p_{\text {mean }}$ is the mean contact pressure.

For the situation in which wear does not occur, the film thickness equation (3.15) shows similarity to the general expression of the minimum film thickness in the EHL regime. All equations discussed above show a great influence of the (inlet) viscosity, velocity and contact pressure on the separation in lubricated contacts.

In Table 3.2 the minimum film thickness calculations for rigid isoviscous (3.14) based on data from wear tests for line contacts are given. Increasing the contact area between rubbing surfaces, for instance due to a small amount of wear, reduces the contact pressure which leads to the formation of a thicker film between the opposing surfaces (see Figure 3.7).

Table 3.2 Minimum film thickness in worn lubricated line contacts.

\begin{tabular}{|c|c|c|c|c|}
\hline \multirow[t]{2}{*}{ Lubricant } & \multirow{2}{*}{$\begin{array}{c}\text { Time } \\
{[\mathrm{h}]}\end{array}$} & \multirow{2}{*}{$\begin{array}{c}\text { Contact } \\
\text { width, } 2 \mathrm{~L}_{\mathrm{w}} \\
{[\mu \mathrm{m}]}\end{array}$} & \multirow{2}{*}{$\begin{array}{c}\text { Mean contact } \\
\text { pressure } \\
{[\mathrm{MPa}]}\end{array}$} & $\mathrm{h}_{\min }[\mathrm{m}]$ \\
\hline & & & & rigid isoviscous \\
\hline \multirow{4}{*}{$\begin{array}{c}\text { Esso } \\
\text { EZL } 799\end{array}$} & 0 & 12.8 & 145.7 & $3.29 \cdot 10^{-9}$ \\
\hline & 4 & 180 & 10.4 & $5.65 \cdot 10^{-8}$ \\
\hline & 8 & 220 & 8.5 & $6.90 \cdot 10^{-8}$ \\
\hline & 12 & 270 & 6.9 & $8.45 \cdot 10^{-8}$ \\
\hline \multirow{4}{*}{$\begin{array}{c}\text { Shell } \\
\text { Vitrea } 150\end{array}$} & 0 & 12.8 & 145.7 & $1.02 \cdot 10^{-8}$ \\
\hline & 4 & 184 & 10.2 & $1.27 \cdot 10^{-7}$ \\
\hline & 8 & 240 & 7.8 & $1.62 \cdot 10^{-7}$ \\
\hline & 12 & 260 & 7.2 & $2.00 \cdot 10^{-7}$ \\
\hline \multirow{4}{*}{$\begin{array}{l}\text { Shell } \\
\text { HVI } 60\end{array}$} & 0 & 12.8 & 145.7 & $9.82 \cdot 10^{-9}$ \\
\hline & 4 & 204 & 9.2 & $1.45 \cdot 10^{-7}$ \\
\hline & 8 & 224 & 8.4 & $1.59 \cdot 10^{-7}$ \\
\hline & 12 & 324 & 5.8 & $2.30 \cdot 10^{-7}$ \\
\hline
\end{tabular}

Input parameters for the calculations are given in Appendix D, Table D.1. 


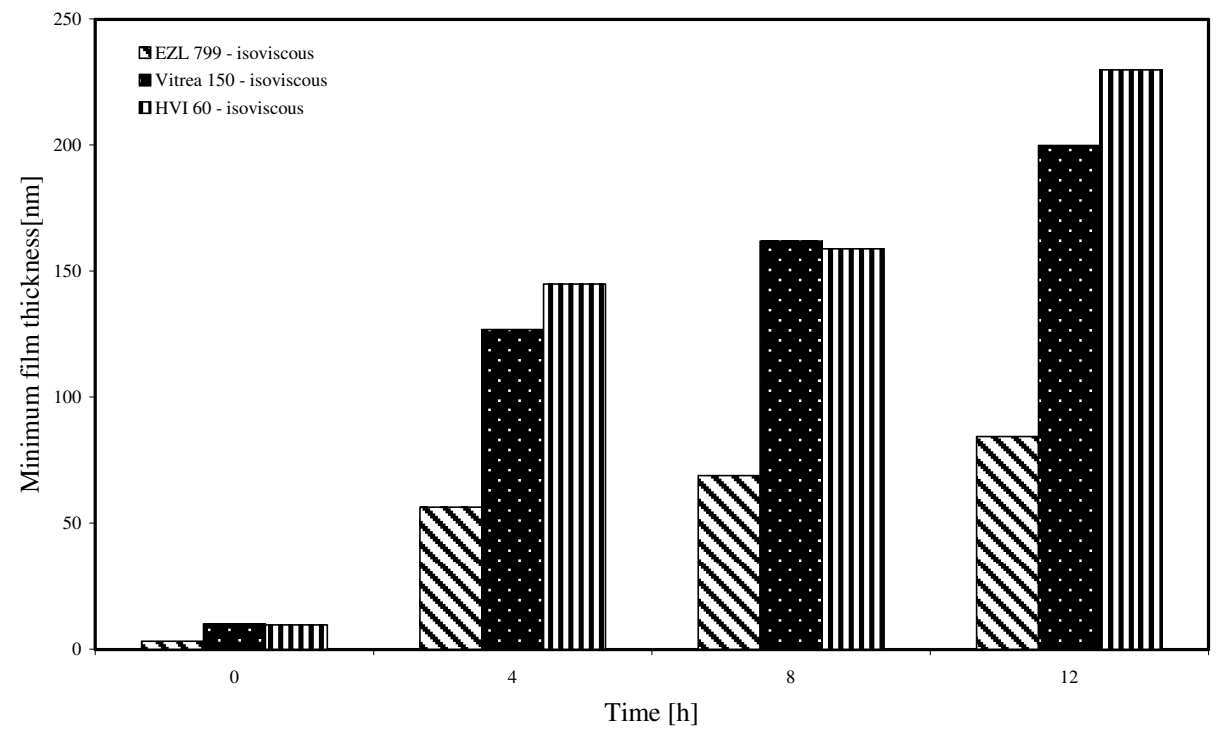

Figure 3.7 Minimum film thickness in worn lubricated line contact for the rigid isoviscous regime for all lubricants used in wear tests, according to (3.14).

\subsubsection{Minimum film thickness in worn elliptical and point contacts}

To observe the influence of wear on friction in worn lubricated elliptical contacts (see experimental results in chapter 5), the contact between a spherical roller and a flat is considered.

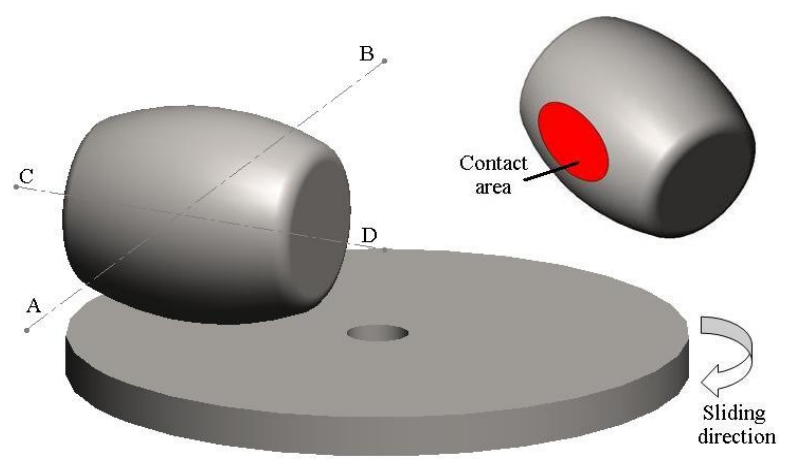




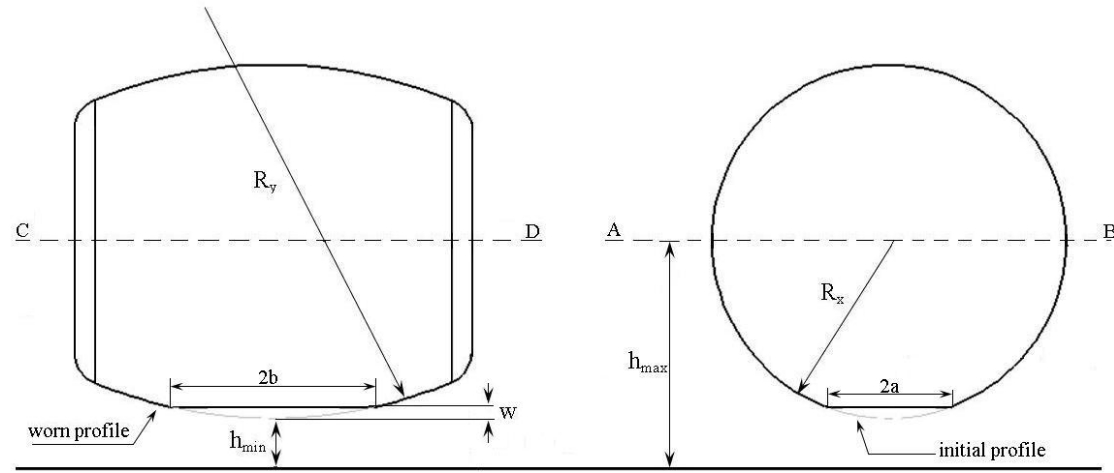

a semi-axis of contact ellipse in sliding direction, $\mathrm{x}$

b semi-axis of contact ellipse perpendicular to sliding direction

$\mathrm{R}_{\mathrm{x}}, \mathrm{R}_{\mathrm{y}}$ radius in $\mathrm{x}$ respectively in $\mathrm{y}$ direction

\section{Figure 3.8 Worn elliptical contact geometry.}

Using changes in contact geometry, a theoretical solution for the minimum film thickness for worn elliptical contacts is proposed.

As it can be seen in Figure 3.8 the profile geometry of the elliptical contact in sliding direction (section A-B) presents the same geometry as the worn line contact. Using this observation and following the same steps specified in section 3.2.2 the maximum pressure in the inlet zone of a worn elliptical contact is found.

$$
\mathrm{p}_{\max }=\frac{3}{4} \eta_{0} \mathrm{v} \frac{1}{\mathrm{~h}_{\min }^{\frac{3}{2}}}\left(-\frac{\mathrm{a}}{\mathrm{h}_{\min }^{\frac{1}{2}}}+\frac{\pi}{\sqrt{2}} \cdot \sqrt{\mathrm{R}_{\mathrm{x}}}\right)
$$

The minimum film thickness in a worn lubricated elliptical contact shows a similar relation as for worn line contacts (3.14) for rigid isoviscous solution in which the parameters: $\delta_{\mathrm{RI}}, \beta_{\mathrm{RI}}$ are calculated according to relation defined above in which the maximum pressure in the inlet region is given by:

$$
\begin{gathered}
\mathrm{p}_{\text {max }}=\mathrm{p}_{\text {mean }}=\frac{\mathrm{F}_{\mathrm{N}}}{\pi \mathrm{ab}} \\
\delta_{\mathrm{RI}}=-\frac{3 \pi}{4 \sqrt{2}} \frac{\eta_{0} \mathrm{~V}}{\mathrm{p}_{\text {mean }}} \sqrt{\mathrm{R}_{\mathrm{x}}} \text { and } \quad \beta_{\mathrm{RI}}=\frac{3}{4} \frac{\eta_{0} \mathrm{~V}}{\mathrm{p}_{\text {mean }}} \mathrm{a}
\end{gathered}
$$


The next step consists in calculating the minimum film thickness of worn point contacts. Since the point contact is considered a special case of the elliptical contact $\left(\mathrm{R}_{\mathrm{x}}=\mathrm{R}_{\mathrm{y}}=\mathrm{R}\right)$ the minimum separation uses the same equations as in the case of the worn elliptical contact where parameters $\delta_{\mathrm{RI}}, \beta_{\mathrm{RI}}$ are calculated using the mean contact pressure in point contacts:

$$
\mathrm{p}_{\text {max }}=\mathrm{p}_{\text {mean }}=\frac{\mathrm{F}_{\mathrm{N}}}{\pi \mathrm{a}_{\mathrm{H}}^{2}}=\frac{\mathrm{F}_{\mathrm{N}}}{\pi \mathrm{L}_{\mathrm{w}}^{2}}
$$

where $\delta_{\mathrm{RI}}=-\frac{3 \pi}{4 \sqrt{2}} \frac{\eta_{0} \mathrm{v}}{\mathrm{p}_{\text {mean }}} \sqrt{\mathrm{R}_{\mathrm{p}}} \quad$ and $\quad \beta_{\mathrm{RI}}=\frac{3}{4} \frac{\eta_{0} \mathrm{v}}{\mathrm{p}_{\text {mean }}} \mathrm{L}_{\mathrm{w}}$

In Figure 3.9 values of the minimum film thickness in worn lubricated elliptical and point contacts are shown. Calculations are made according to experimental data from wear tests (see Table D.2 and Table D.3 from Appendix D).

a)

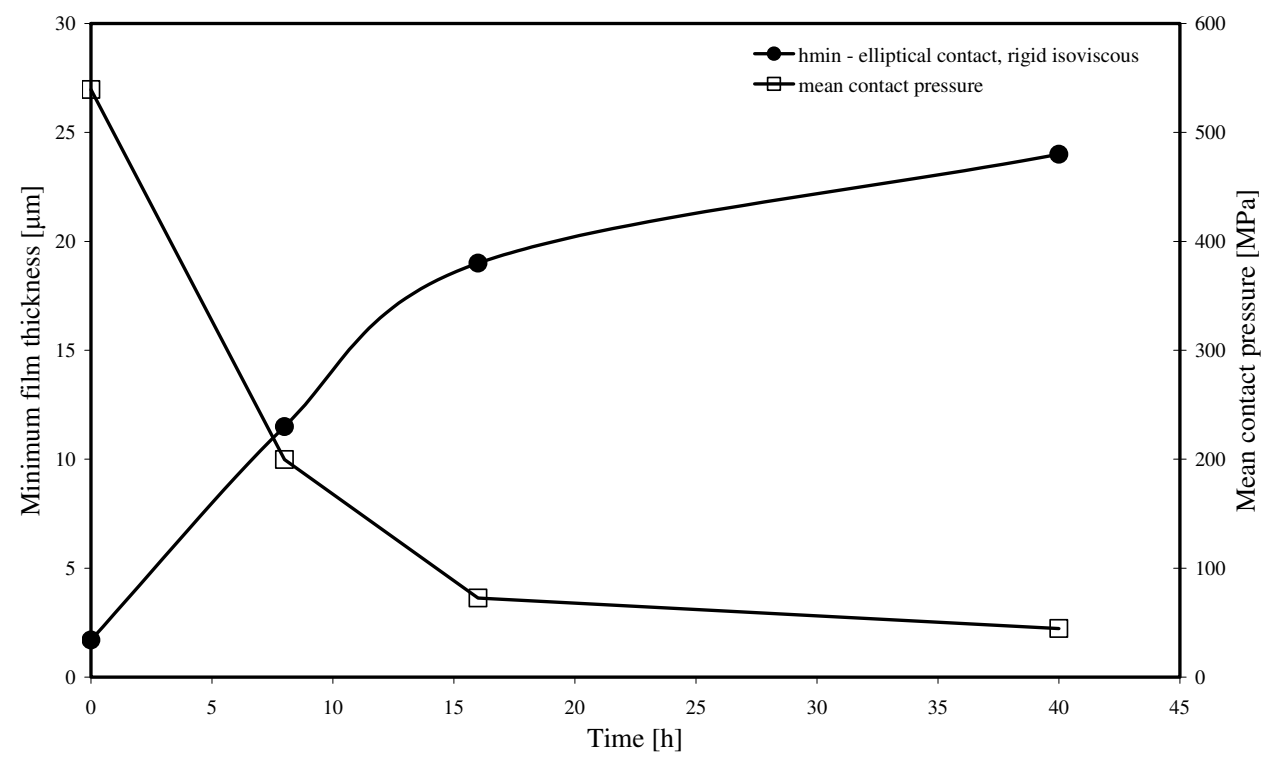


b)

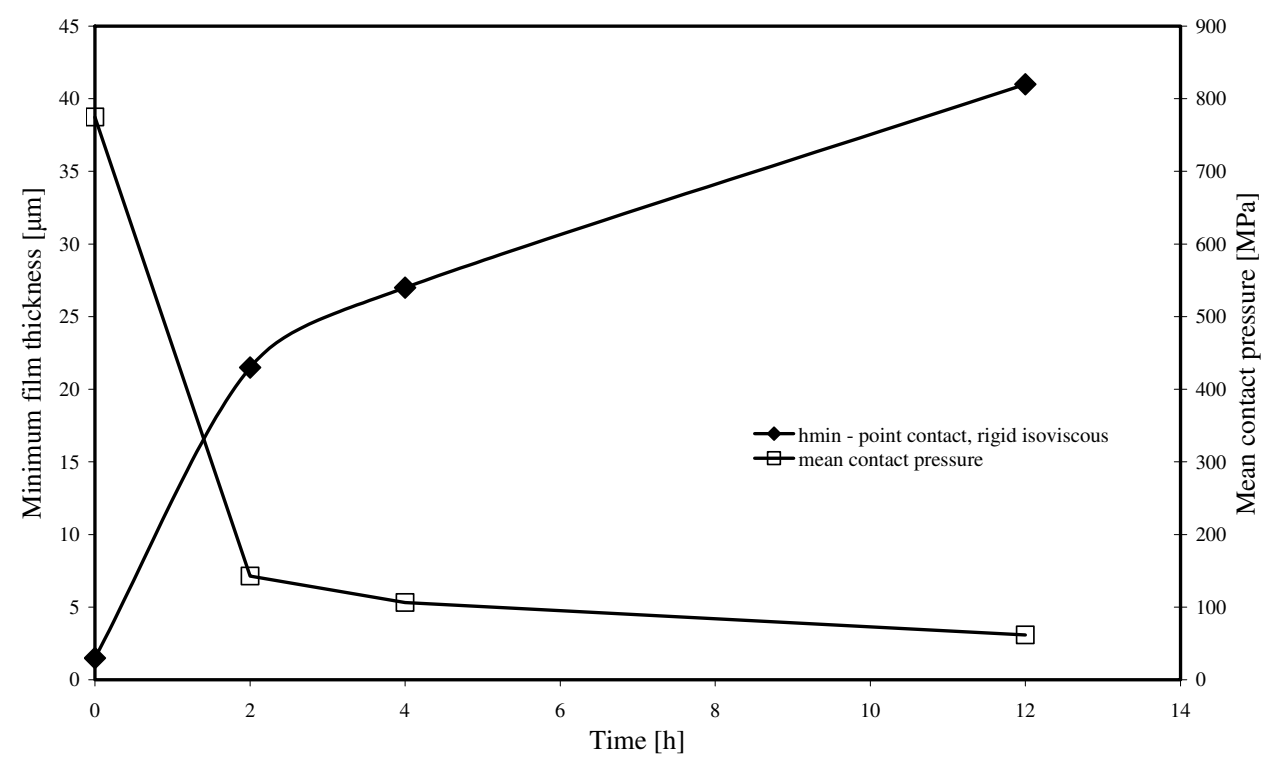

Figure 3.9 Minimum film thickness and mean contact pressure in a) worn lubricated elliptical contact and b) worn lubricated points contact.

\subsection{Influence of elasticity on the minimum film thickness in worn lubricated concentrated contacts}

In section 3.2 it was shown that macroscopic wear (large contact area) leads to a decrease in contact pressure and by that the contacting bodies behave as rigid solids (rigid isoviscous), thereby obtaining a significant increase in separation. In this section the gap between the no wear situation, i.e. elasto-hydrodynamic lubricated contacts, and macroscopic wear on the minimum film thickness in lubricated concentrated contacts is investigated.

To find this link it is assumed that for the cases in which a worn contact area is close to the size of the Hertzian contact area (bodies are deformed due to high contact pressure), the minimum lubricant film thickness is close to the one as given by Moes [6] (see film thickness for EP regime from Appendix C).

In the case of an unworn lubricated line contact, the minimum film thickness in EP regime (high loads) according to Moes reads as: 


$$
\mathrm{h}_{\operatorname{minEP}}=1.473\left(\alpha \eta_{0} \vee \mathrm{R}^{\frac{2}{3}} \mathrm{~b}_{\mathrm{H}}^{-\frac{1}{3}}\right)^{\frac{3}{4}}
$$

In which $\alpha$ is the viscosity-pressure coefficient $\left[\mathrm{Pa}^{-1}\right], \eta_{0}$ is the lubricant viscosity $[\mathrm{Pa} \cdot \mathrm{s}], \mathrm{v}$ is the velocity $[\mathrm{m} / \mathrm{s}], \mathrm{R}$ is the radius of the cylinder $[\mathrm{m}], b_{H}$ is the half width of the Hertzian contact [m].

For worn line contacts the minimum film thickness, $\mathrm{h}_{\operatorname{minRI}}$ is shown in equation (3.14). Combining the equation (3.14) and (3.22) the film thickness in worn lubricated line contact in which elasticity is included reads:

$$
\mathrm{h}_{\min }=\left(\mathrm{h}_{\operatorname{minRI}}^{\mathrm{n}}+\mathrm{h}_{\operatorname{minEP}}^{\mathrm{n}}\right)^{\frac{1}{\mathrm{n}}}, \text { where } \mathrm{n}=8
$$

For line contacts the value of $\mathrm{n}$ is 8 which is in accordance with [6] and [9]. From Figure 3.10 it is observed that when the wear scar is of the same size of the Hertzian contact area, the film thickness according to Moes is higher than the film thickness from the rigid isoviscous calculations due to influence of the elastic deformation of the surfaces and for larger $\mathrm{L}_{\mathrm{w}} / \mathrm{b}_{\mathrm{H}}$ values the rigid-isoviscous film thickness is larger than the EHL solution as shown in Figure 3.7 or Table 3.2.

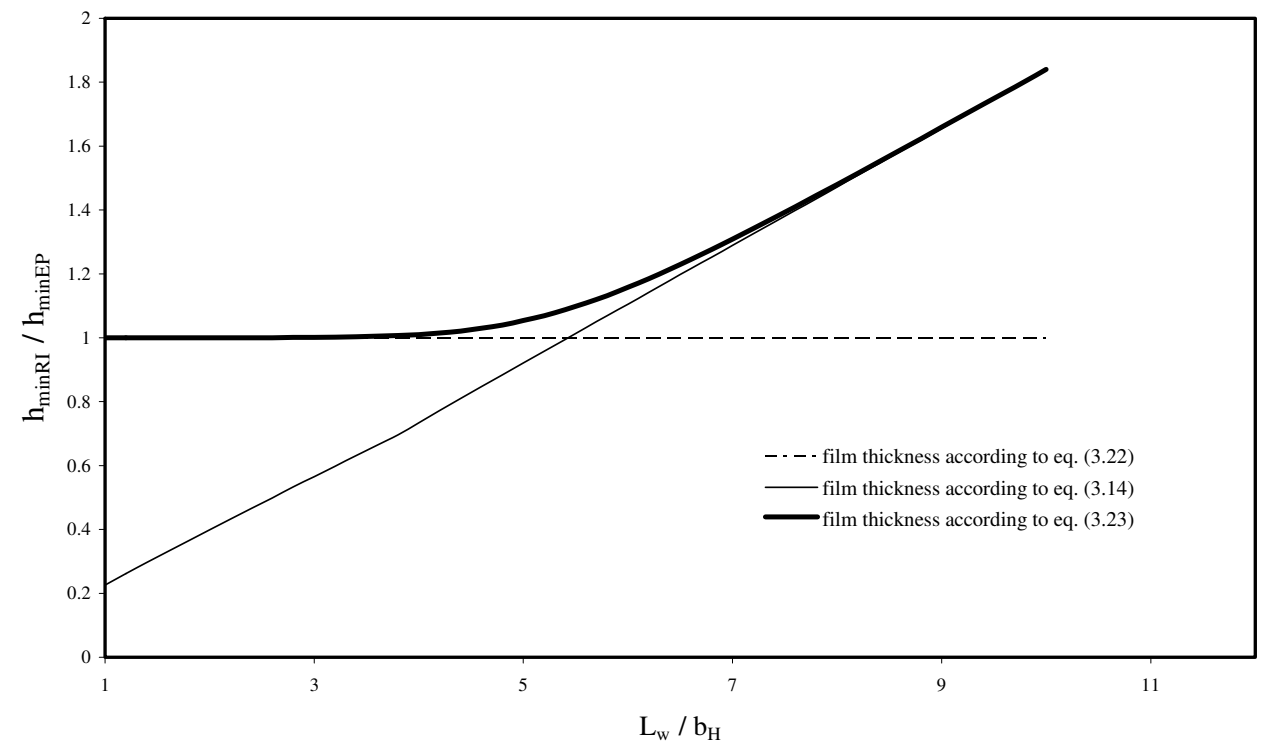

Figure 3.10 Minimum film thickness in worn lubricated line contact including elasticity. 
The minimum film thickness for point and elliptical contact according to Moes is:

$$
\begin{gathered}
\mathrm{h}_{\operatorname{minEP}}=1.2902\left(\alpha \eta_{0} v \mathrm{R}_{\mathrm{p}}^{\frac{2}{3}} \mathrm{a}_{\mathrm{H}}^{-\frac{1}{3}}\right)^{\frac{3}{4}} \text {, point contact } \\
\mathrm{h}_{\operatorname{minEP}}=\mathrm{C}_{\mathrm{EP}}\left(\alpha \eta_{0} \mathrm{va}^{-\frac{1}{3}} \alpha_{\mathrm{E}}^{\frac{1}{3}}\right)^{\frac{3}{4}} \lambda^{-\frac{1}{24}} \mathrm{R}_{\mathrm{red}}^{\frac{1}{12}} \mathrm{R}_{\mathrm{x}}^{\frac{5}{12}} \text {, elliptic contact }
\end{gathered}
$$

In which a is the semi-axis of contact ellipse in sliding direction $\mathrm{x}, \mathrm{C}_{\mathrm{EP}}$ is a constant equal to $1.48 \cdot 3^{\frac{1}{12}} \cdot\left(1+0.006 \ln (\lambda)+0.63 \cdot \lambda^{4 / 7}\right)^{-7 / 20}$, where $\lambda=R_{x} / R_{y}$. For the definition of the other parameters the reader is referred to section A.2, Appendix A. In the case of a worn elliptic and point contact the minimum film thickness is represented by the general equation, in which the value of $n$ is in accordance with [6]:

$$
\mathrm{h}_{\min }=\left(\mathrm{h}_{\operatorname{minRI}}^{\mathrm{n}}+\mathrm{h}_{\operatorname{minEP}}^{\mathrm{n}}\right)^{\frac{1}{\mathrm{n}}} \text {, where } \mathrm{n}=5
$$

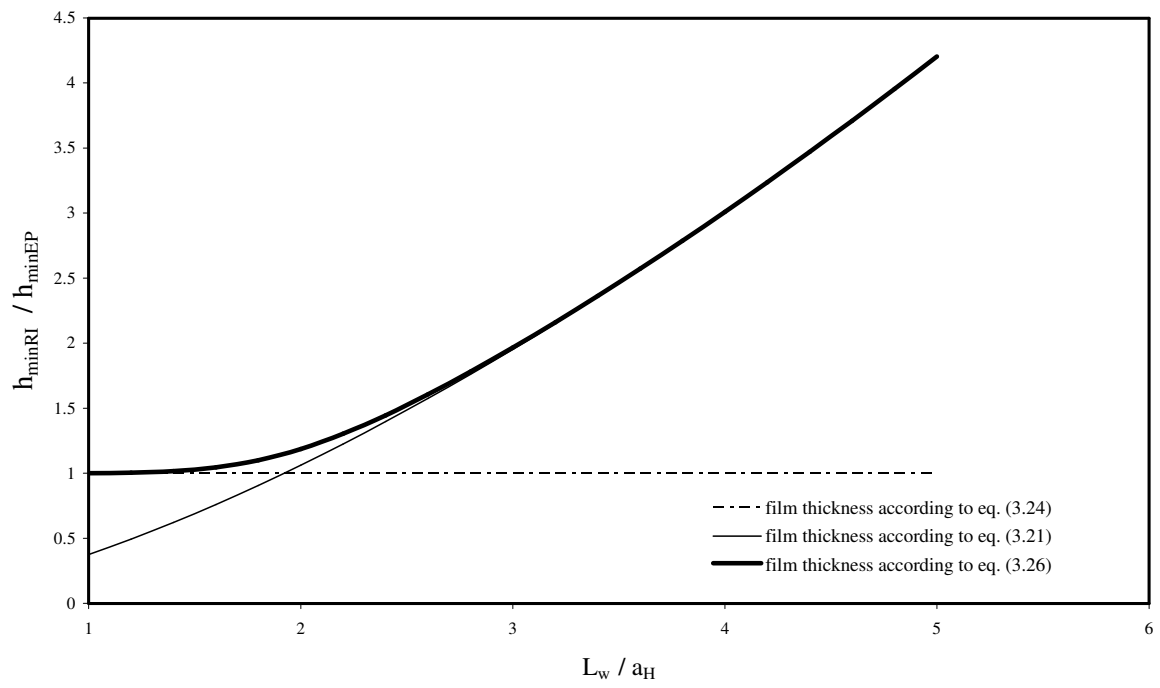

Figure 3.11 Minimum film thickness in worn lubricated point contact including elasticity, $R_{x} / R_{y}=1$. 


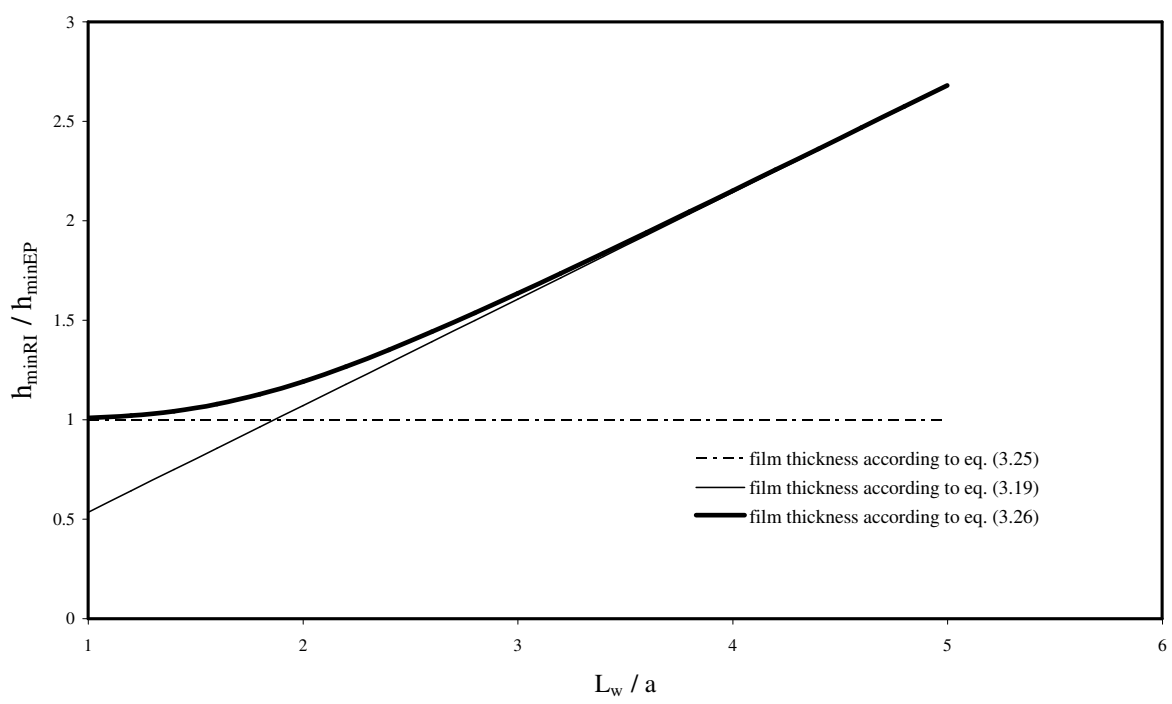

Figure 3.12 Minimum film thickness in worn lubricated elliptic contact including elasticity, $R_{x} / R_{y}=0.15$.

\subsection{Conclusions}

Theoretical results show that by increasing wear in lubricated contacts, i.e. contact area increases and leading to a decrease in mean contact pressure, cause an increase in the separation between the opposing surfaces.

Minimum film thickness in worn lubricated concentrated contacts in which elasticity is included is given and will be used in the mixed lubrication friction model (see next chapter) to predict friction in worn lubricated concentrated contacts.

\subsection{References}

[1] Qu, J. and Truhan, J.J., "An efficient method for accurately determining wear volume of sliders with non-flat wear scars and compound curvatures", Wear, Vol. 261, 2006, pp. 848-855.

[2] Cameron, A., "The Principles of Lubrication", Longmans Green and Co Ltd., London, 1966, pp. 49-79.

[3] Barus, C., "Isothermals, isopiestics and isometrics relative to viscosity", American Journal of Science, Vol. 45, 1893, pp. 87-96. 
[4] Schipper, D.J., "Transitions in the lubricated concentrated contacts", $\mathrm{PhD}$ thesis, University of Twente, The Netherlands, 1988.

[5] Taylor, R.I., "Lubrication, Tribology \& Motorsport", Shell Global Solution, UK, 2002, report no. 2002-01-3355.

[6] Moes, H., "Lubrication and beyond", Print Partners Ipskamp B.V., Enschede, The Netherlands, 2000, pp. 176-180.

[7] van Beek, A., "Advanced engineering design - Lifetime performance and reliability", TU Delft, The Netherlands, 2006, pp. $321-320$.

[8] ten Napell, W.E., "Elastohydro-dynamische smering", Student Guide Twente University - 115536, 1995, chapter 2, pp. 1-9.

[9] Liu, Q., "Friction in mixed and elastohydrodynamic lubricated contacts including thermal effects", $\mathrm{PhD}$ thesis, University of Twente, The Netherlands, 2002, pp. 93-95. 


\section{Chapter 4 Mixed lubrication friction model}

\subsection{Introduction}

In this chapter a deterministic mixed lubrication friction model is presented in order to predict the frictional behaviour of worn lubricated concentrated contacts. The friction model is based on the assumption that in the ML regime the total load on the system is shared between asperity interaction and hydrodynamic action which was presented for the first time by Johnson et al. [1]. After that researchers started to predict friction for different contact geometries: for instance line [2] and [3], point [4] and elliptical [5]. In all references which are listed with respect to this subject the main goal was to predict friction in lubricated contacts without wear.

In this research a modification of the aforementioned mixed lubrication friction model is proposed in order to investigate the friction behaviour in worn lubricated contacts. Experimental tests described in chapter 5 show that by increasing the operational time of a mixed lubricated system the geometry of the components change.

Based on this observation a new formula for the minimum film thickness (hydrodynamic component) which takes into consideration the change in geometry was developed in the previous chapter. The load carried by the asperities in the ML regime is calculated using contact surface measurements after the friction tests (deterministic model).

\subsection{Mixed lubrication friction model}

As mentioned above the friction model will use the assumption for the ML regime in which the total load of the systems is carried by asperity (BL) and hydrodynamic (HL) force components.

$$
\mathrm{F}_{\mathrm{N}}=\mathrm{F}_{\mathrm{C}}+\mathrm{F}_{\mathrm{H}}
$$

In which $F_{N}$ is the total load on the system, $F_{C}$ the load carried by the interacting asperities and $F_{H}$ the load carried due to hydrodynamic action. According to [1] equation (4.1) transforms in terms of pressure in: 


$$
\mathrm{p}_{\mathrm{N}}=\mathrm{p}_{\mathrm{C}}+\mathrm{p}_{\mathrm{H}}
$$

where: $p_{i}=F_{i} / A_{\text {nom }}$ in which $\mathrm{i}=\mathrm{N}, \mathrm{H}$ or $\mathrm{C}$ and $\mathrm{A}_{\text {nom }}$ is the nominal contact area.

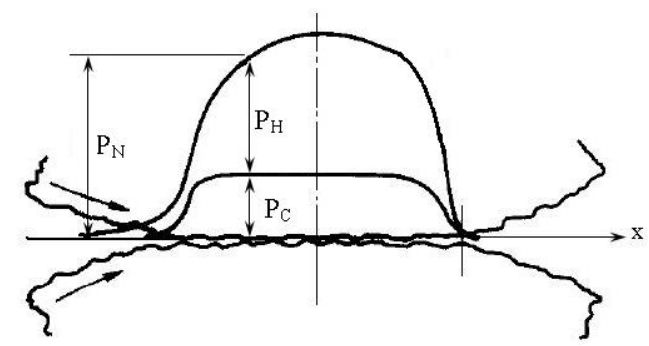

Figure 4.1 Pressure distribution in a mixed lubrication contact according to [1].

To proceed with the calculation two coefficients $\gamma_{1}$ and $\gamma_{2}$ are used and they are mutually dependent through the condition from equation (4.3).

$$
\gamma_{1}=\frac{\mathrm{F}_{\mathrm{N}}}{\mathrm{F}_{\mathrm{H}}}=\frac{\mathrm{P}_{\mathrm{N}}}{\mathrm{P}_{\mathrm{H}}}, \gamma_{2}=\frac{\mathrm{F}_{\mathrm{N}}}{\mathrm{F}_{\mathrm{C}}}=\frac{\mathrm{P}_{\mathrm{N}}}{\mathrm{P}_{\mathrm{C}}} \text { condition } 1=\frac{1}{\gamma_{1}}+\frac{1}{\gamma_{2}}
$$

Using these two coefficients and combining a deterministic multi-asperity contact model with (E)HL theory in which a new formula for the film thickness for worn concentrated contacts is used, the entire Stribeck curve can be calculated as discussed in the next subsections.

\subsubsection{Hydrodynamic component}

To determine the hydrodynamic component the main parameter to be calculated is the lubricant film thickness which separates the two opposing surfaces. In the case of worn lubricated contacts the traditional EHL film thickness formulas [6] cannot be used.

To understand the influence of wear on contact geometry and as a result on film formation, experimental tests were conducted for different types of lubricant (chapter 5) to study the evolution of sample profile in time. Using the obtained profile geometry in the Reynolds equation in combination with the force equilibrium equation the lubricant film thickness is found. The steps for obtaining the lubricant film thickness for worn lubricated contacts were presented in chapter 3. 


\subsubsection{Asperity component}

Data from experimental friction tests will be compared with the calculated friction of the mixed lubrication friction model having as input the surface topography of the surface specimen after the friction test.

When the surface is measured, for instance, by interference microscopy, the surface is characterized using the theory from [7]. According to this a point on a surface is considered a summit only if its 8 surrounding points are lower (9-points summit definition). The shape of the asperities is considered as an ellipsoid which is determined by height $\mathrm{z}_{\mathrm{i}}$ and two radii of curvature in the main directions (in and perpendicular to the sliding direction).

The contact between a rough surface and a smooth rigid flat is depicted in Figure 4.2. In the case of elastic deformation, the initial contact area and load is calculated according to Hertz (see Appendix A).

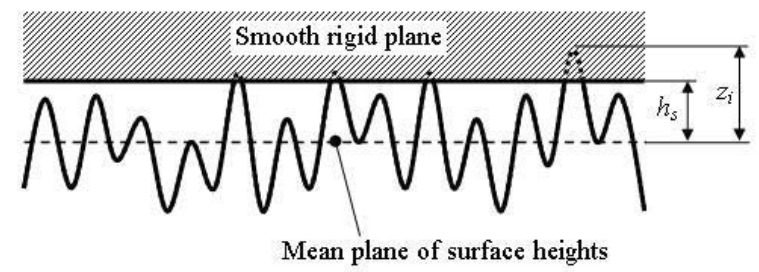

Figure 4.2 Contact between a smooth rigid flat and a rough surface [5].

The load carried by the asperities $F_{C}$ and asperity contact area $A_{C}$ are found by summation of each individual microcontact and are presented below:

$$
\begin{aligned}
& \mathrm{F}_{\mathrm{C}}=\sum_{\mathrm{i}=1}^{\mathrm{N}} \mathrm{F}_{\mathrm{i}}\left(\delta_{\mathrm{i}}\right) \\
& \mathrm{A}_{\mathrm{C}}=\sum_{\mathrm{i}=1}^{\mathrm{N}} \mathrm{A}_{\mathrm{i}}\left(\delta_{\mathrm{i}}\right)
\end{aligned}
$$

where $\mathrm{N}$ is the number of asperities in contact $\delta_{\mathrm{i}}=\mathrm{z}_{\mathrm{i}}-\mathrm{h}_{\mathrm{s}}$ is the deformation depth or asperity indentation. 


\subsubsection{Separation}

In the ML regime rough surfaces are coming in contact and an average film thickness can be defined. In [1] this film thickness is approximated by the crosssectional area of the gap between two undeformed Gaussian distributed profiles divided by the gap length. As mentioned before the model is a deterministic friction model. The film thickness is computed as the volume between the two surfaces divided by the nominal contact area. The film thickness reads as:

$$
\mathrm{h}=\frac{1}{\mathrm{n}} \sum_{\mathrm{j}=1}^{\mathrm{n}}\left\langle\mathrm{h}_{\mathrm{s}}-\mathrm{z}_{\mathrm{i}}\right\rangle
$$

where $\mathrm{n} \quad$ is the number of grid points

$\mathrm{z}_{\mathrm{i}} \quad$ is the height relative to the mean plane of surface heights.

$<\quad$ Macauley brackets, i.e. negative values are neglected.

\subsubsection{Calculation of coefficient of friction}

After solving (4.1), (3.23 or 3.26), (4.4) and (4.6) the next step consists of calculating the coefficient of friction which is assumed to be the sum of the friction of the BL and the HL components. In the next sections the calculation of the coefficient of friction for each lubrication regime is presented.

\subsubsection{Friction in $\mathrm{BL}$}

The friction force in BL regime is calculated as the sum of all friction forces present in each micro-contact.

$$
\mathrm{F}_{\mathrm{f}, \mathrm{BL}}=\sum_{\mathrm{i}=1}^{\mathrm{N}} \iint_{\mathrm{A}_{\mathrm{Ci}}} \tau_{\mathrm{Ci}} \mathrm{dA}_{\mathrm{i}}
$$

where: $\tau_{\mathrm{Ci}}$ is the shear stress at the $\mathrm{i}^{\text {th }}$ asperity contact

$\mathrm{A}_{\mathrm{i}} \quad$ is the contact area of the $\mathrm{i}^{\text {th }}$ asperity contact

$\mathrm{N}$ is the number of micro-contacts. 
In this thesis the friction between contacting asperities is considered to be of the Coulomb type $\mathrm{f}_{\mathrm{Ci}}=\tau_{\mathrm{Ci}} / \mathrm{p}_{\mathrm{Ci}}$ and the coefficient of friction is assumed to be constant for all asperities $\mathrm{f}_{\mathrm{Ci}}=\mathrm{f}_{\mathrm{C}}$. Using the above assumptions equation (4.7) transforms in:

$$
\mathrm{F}_{\mathrm{f}, \mathrm{BL}}=\mathrm{f}_{\mathrm{c}} \sum_{\mathrm{i}=1}^{\mathrm{N}} \iint_{\mathrm{A}_{\mathrm{Ci}}} \mathrm{p}_{\mathrm{Ci}} \mathrm{dA} \mathrm{A}_{\mathrm{i}}=\mathrm{f}_{\mathrm{C}} \mathrm{F}_{\mathrm{C}}
$$

In all the calculations the Coulomb coefficient of friction will take the value of the coefficient of friction in BL from experimental friction tests corresponding to each type of concentrated contact.

\subsubsection{Friction in HL}

In the case of sliding contacts, the friction in HL is caused by shearing the lubricant in the contact zone due to relative motion of the surfaces. Based on the lubricant's rheological behaviour the hydrodynamic shear stress $\tau_{\mathrm{H}}$ can be defined as a function of the shear rate $\dot{\gamma}$ [8], in these calculations the Eyring model is used:

$$
\tau_{\mathrm{H}}=\tau_{0} \operatorname{arcsinh}\left(\frac{\eta \dot{\gamma}}{\tau_{0}}\right)
$$

where: $\tau_{0}$ is the Eyring shear stress

$\eta \quad$ is the dynamic viscosity

The friction force in HL is obtained by the integration of the shear stress over the contact area:

$$
\mathrm{F}_{\mathrm{f}, \mathrm{HL}}=\iint_{\mathrm{A}_{\mathrm{H}}} \tau_{\mathrm{H}}(\dot{\gamma}) \mathrm{dA}_{\mathrm{H}}=\tau_{0} \mathrm{~A}_{\mathrm{H}} \operatorname{arcsinh}\left(\frac{\eta v^{\mathrm{dif}}}{\tau_{0} \mathrm{~h}}\right)
$$

with $\mathrm{A}_{\mathrm{H}}=\mathrm{A}_{\mathrm{nom}}-\mathrm{A}_{\mathrm{C}} \quad$ is the hydrodynamic contact area

$\mathrm{A}_{\mathrm{C}} \quad$ is the asperity contact area and is given in (4.5)

$\mathrm{v}^{\mathrm{dif}} \quad$ is the relative motion between the opposing surfaces. 


\subsubsection{Friction in ML}

Calculation of the friction force in ML is done by summing the two friction forces presented in equation (4.8) for the BL component respectively (4.10) for the HL component.

$$
F_{f, M L}=F_{f, B L}+F_{f, H L}
$$

The coefficient of friction in the ML regime is calculated using the definition of coefficient of friction $f=F_{f} / F_{N}$ and is given in the next equation:

$$
f=\frac{f_{C} F_{C}+\tau_{0} A_{H} \operatorname{arcsinh}\left(\frac{\eta v^{\text {dif }}}{\tau_{0} h}\right)}{F_{N}}
$$

\subsection{Stribeck curve calculation for worn lubricated contacts}

The transition between the three lubrication regimes is represented in the generalized Stribeck curve (coefficient of friction as a function of the velocity on a logarithmic scale). In this thesis the friction will be calculated by a deterministic mixed lubrication friction model as presented in section 4.2. Based on the theory presented in previous sections the solution scheme for the coefficient of friction calculation is presented in Figure 4.3.

For the calculation, the following input parameters are required: load, sliding velocity, contact geometry, lubricant properties (viscosity $\eta$, viscosity pressure coefficient $\alpha$, Eyring shear stress $\tau_{0}$ ) and surface topography of the wear scar of the pin after friction tests.

Using the solution scheme given in Figure 4.3 the influence of several parameters on the Stribeck curve is investigated for line contacts. Figure 4.4 shows the influence of wear on friction in worn lubricated sliding line contacts. These results are particularly of importance for systems operating near the ML/BL transition which require a high value of the coefficient of friction. 


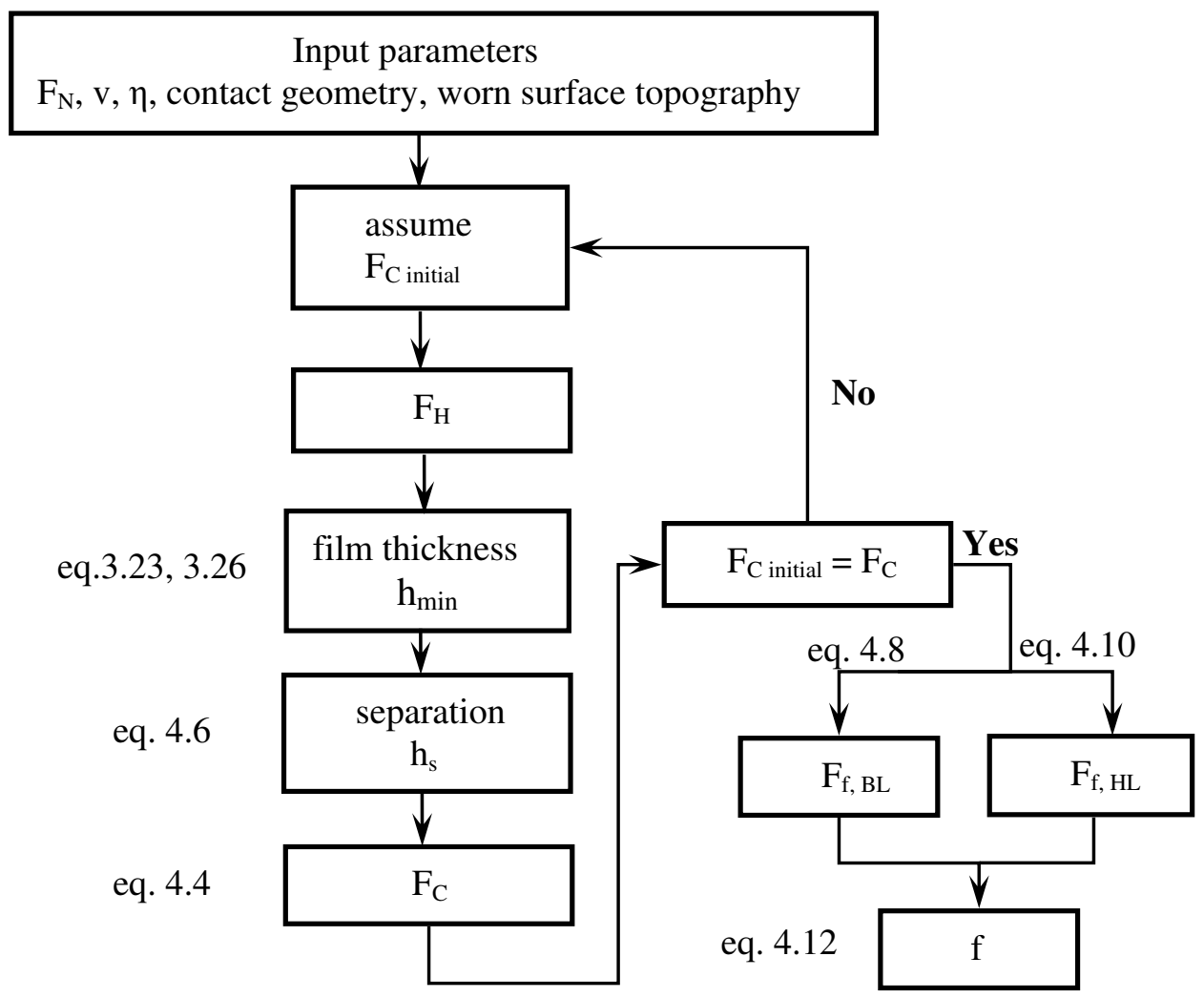

Figure 4.3 Solution scheme for the coefficient of friction calculation.

By increasing wear (contact width, $2 \mathrm{~L}_{\mathrm{w}}$ ) in these contacts, calculations show that friction decreases allowing a shift (change of the operational regime from BL to ML) of the Stribeck curve to the left (see Figure 4.4). This change can be attributed to hydrodynamics effects (increase of the separation) that occur between contacting surfaces and are mainly due to a decrease in contact pressure.

This is explained as follows: in general the film thickness $\mathrm{h}$ is dependent on the ratio $\mathrm{h} \div(\eta \mathrm{v} / \mathrm{p})^{\mathrm{n}}$ in which $\eta$ is the dynamic viscosity of the lubricant, $\mathrm{v}$ is the velocity, $\mathrm{p}$ is the contact pressure and $\mathrm{n}$ is a coefficient. Due to wear, contact pressure reduces and as a consequence $\mathrm{h}$ increases for a certain value of $\eta$ and $\mathrm{v}$. 


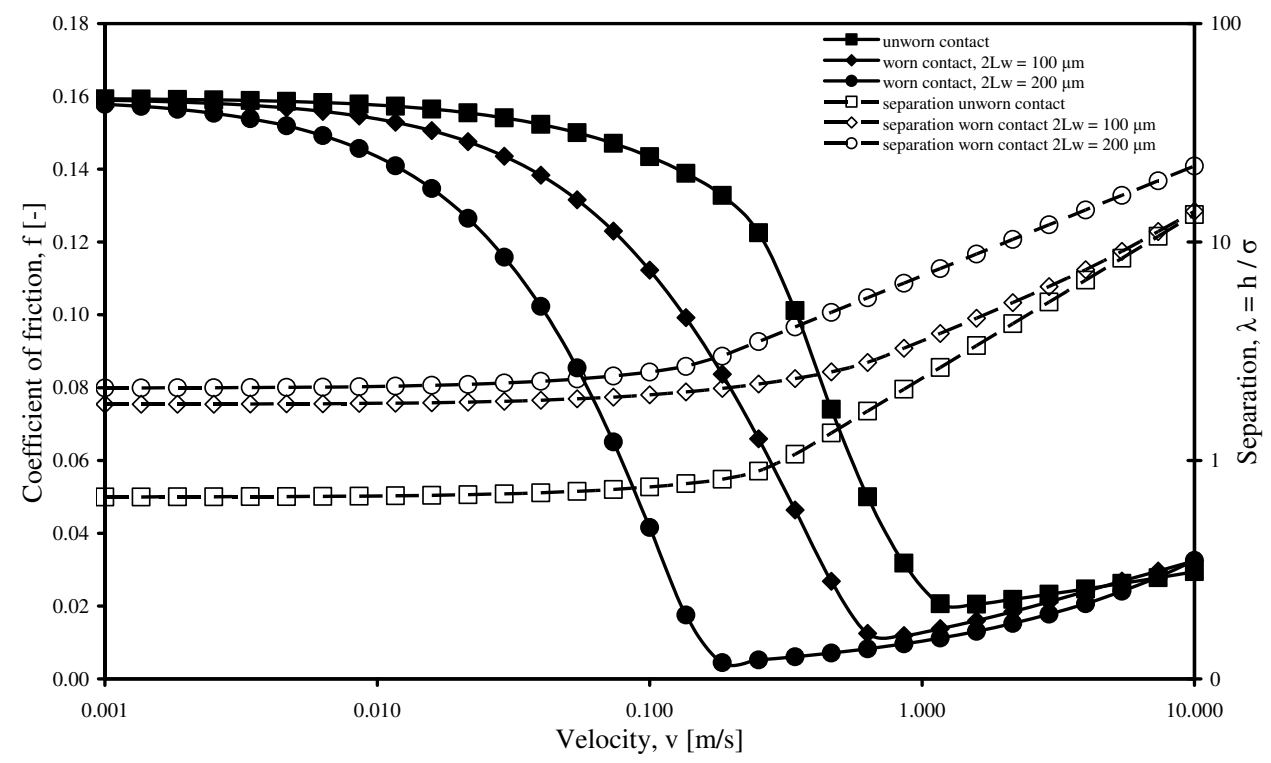

Figure 4.4 Influence of wear on the friction in lubricated line contacts, results from ML friction model using input parameters from Table D.4, Appendix D.

\subsection{Conclusions}

In this chapter a deterministic mixed lubrication friction model is discussed and used for the prediction of the Stribeck curve for worn lubricated concentrated contacts. The friction model is based on the assumption that the total load is shared between the interacting asperities and hydrodynamic action. For friction calculations a solution scheme (Figure 4.3) is given in which load, velocity, lubricant properties, contact geometry, worn surface topography are used as input parameters. For the asperity interaction a contact model to calculate the load carried by asperities in a worn contact is described. For the hydrodynamic action, solutions of the film thickness for each concentrated contact (line, point and elliptical) proposed in chapter 3 can be used.

The results show that by increasing wear in lubricated contacts a decrease in friction occurs and leads to a shift of the Stribeck curve to the left which means a change in the operational regime (for instance BL to ML). This change can be attributed to hydrodynamics effects which occur in the contact due to a decrease in the contact pressure and with that an increase in separation. 
One should keep in mind that the shift in the Stribeck curve in Figure 4.4 is caused by a small wear depth. The shift observed is a result of a wear depth of only 2.5 $\mu \mathrm{m}$.

\subsection{References}

[1] Johnson, K.L., Greenwood, J.A. and Poon, S.Y. "A simple theory of asperity contact in elasto-hydrodynamic", Wear, Vol. 19, Issue 1, 1972, pp. 91-108.

[2] Lu, X., Khonsari, M.M and Gelinck, E.R.M. "The Stribeck curve: experimental results and theoretical prediction", Journal of Tribology, Vol.128, 2008, pp. 789-794.

[3] Faraon, I. "Stribeck curve for starved line contacts", Journal of Tribology, Vol. 129, 2007, pp.181-187.

[4] Liu, Q., Napel, W.E. ten, Tripp, J.H. Lugt, P.M. and Meeuwenoord, R. "Friction in highly loaded mixed lubrication point contacts", Tribology Transaction, Vol. 52, 2009, pp. 360-369.

[5] Popovici, R.I. "Friction in wheel - rail contacts", $\mathrm{PhD}$ thesis, University of Twente, The Netherlands, 2010.

[6] Moes, H. "Lubrication and beyond", Print Partners Ipskamp B.V., Enschede, 2000, pp. 155-186.

[7] Rooij, M.B. "Tribological aspects of unlubricated deepdrawing process", $\mathrm{PhD}$ thesis, University of Twente, The Netherlands, 1998.

[8] Evans, C.R. "Measurement and mapping of the rheological properties of elastohydrodynamic lubricants", $\mathrm{PhD}$ thesis, University of Cambridge, 1983. 


\section{Chapter 5 Experimental results}

\subsection{Introduction}

This chapter presents the specifications of the experimental devices used for validation of the theoretical results and the experimental procedure as well as results. The first section 5.2 describes the pin-on-disc tribometer on which wear and friction tests were performed for determining the influence of macroscopic wear on the Stribeck curve. The characterization of the wear scars and surface topography were investigated by SEM as well as interference microscope. Based on the experimental procedure given in 5.4 the experimental results for all three types of contacts are presented in section 5.5.

\subsection{Experimental devices}

\subsubsection{Pin-on-disc tribometer}

Wear and friction measurements in lubricated contacts were performed on a pinon-disc tribometer (see Figure 5.1) and for each contact a holder was designed.

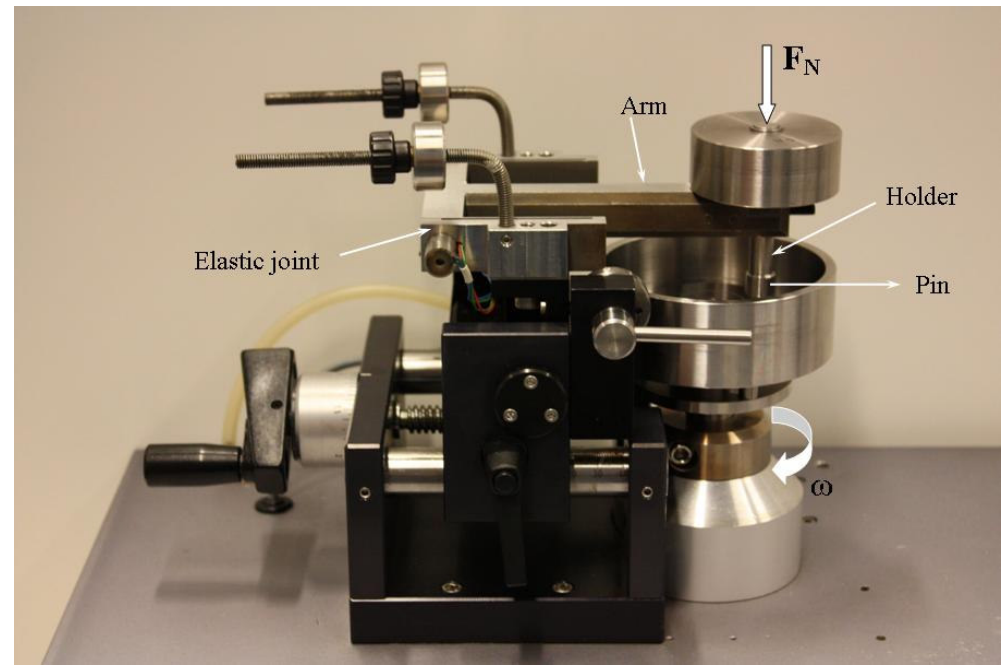


a)

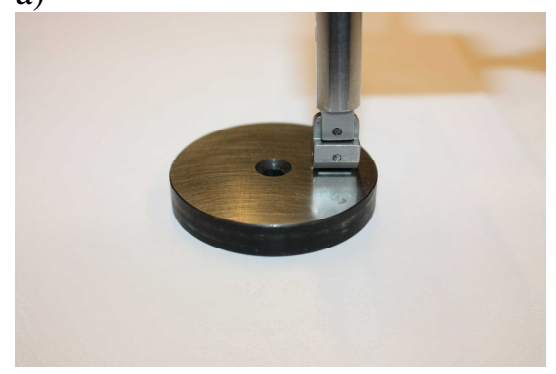

b)

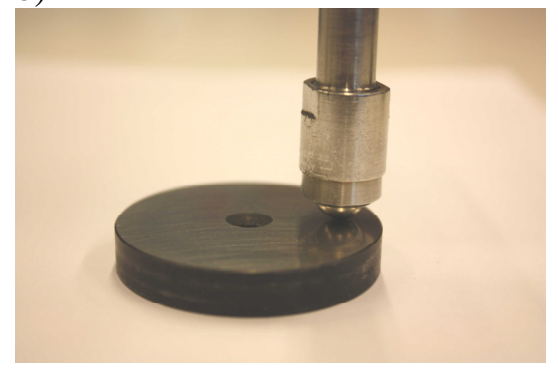

c)

Figure 5.1 Pin-on-disc sliding tester and pin holder configuration

a) line contact, b) point contact and c) elliptical contact.

A pin-on-disc tribometer consists of a stationary pin under an applied load in contact with a rotating disc mounted on a motor which is driven by a controller connected to a computer. The pin is placed in a special holder designed for each type of contact and is attached to an arm which is held by two elastic joints. The friction force is measured by a displacement transducer attached to the elastic joint.

\subsubsection{Interference microscope}

The changes in surface topography of the pins as a result of the wear and friction tests were performed by an interference microscope (Micromap 560). Using the wear scar measurements the evolution of the profile geometry during wear tests was found. Some of the interference microscope characteristics are given: height resolution: approx. $1 \mathrm{~nm}$, size of a surface measurement: min. 110x85 $\mu \mathrm{m}$, max. $4.42 \times 3.45 \mathrm{~mm}$ (depending on magnification, resolution) and number of measurement points (pixels): $304 \times 228$ or $640 \times 478$. 

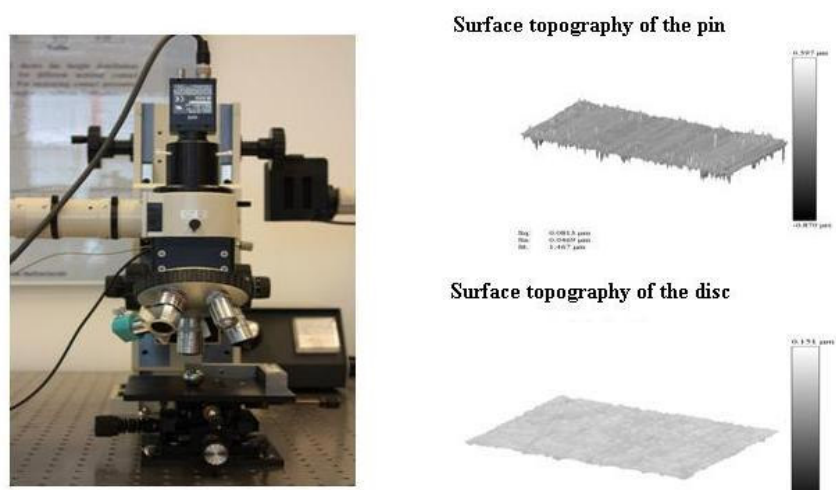

Surface topography of the disc

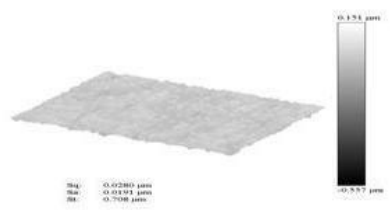

Figure 5.2 Interference microscope.

\subsubsection{Scanning electron microscope (SEM)}

The JCM-5000 NeoScope is used to characterize the wear scars dimension from worn samples after the wear and friction tests. It gives high magnification images (magnification $20000 \mathrm{X}$ ) with high resolution and large depth of field. The NeoScope operates in low and high vacuum modes and no special sample preparation is necessary like coatings or drying.

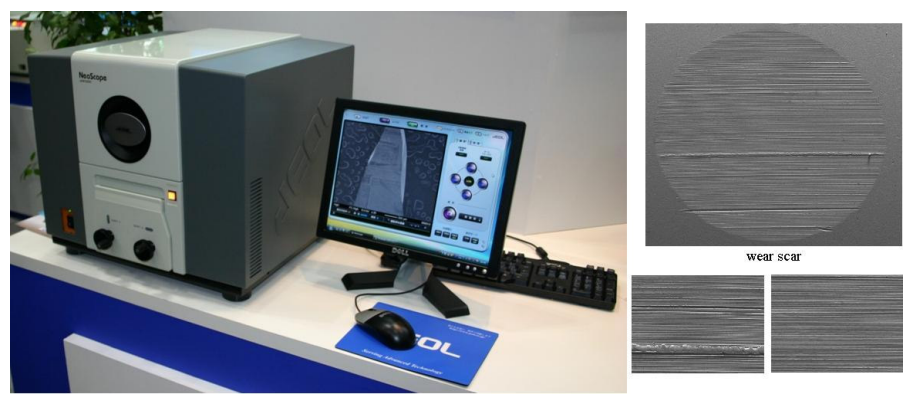

Figure 5.3 SEM JCM - 5000 NeoScope from Joel.

\subsection{Sample geometry}

To investigate the influence of macroscopic wear in lubricated contacts different pin geometries were considered. 
Table 5.1 Pin and flat geometry.

\begin{tabular}{|c|c|c|c|c|}
\hline Contact & Pin geometry* & Dimensions [m] & Material & Hardness \\
\hline Line & Roller bearing & $\mathrm{R}=2 \cdot 10^{-3}, \mathrm{~B}=8 \cdot 10^{-3}$ & \multirow{5}{*}{$\begin{array}{c}\text { AISI } \\
52100\end{array}$} & \multirow{3}{*}{$\begin{array}{l}60-66 \\
\text { HRC }\end{array}$} \\
\hline Point & Ball bearing & $\mathrm{R}=5 \cdot 10^{-3}$ & & \\
\hline Elliptical & Spherical roller & $\mathrm{R}_{\mathrm{x}}=4 \cdot 10^{-3}, \mathrm{R}_{\mathrm{y}}=26.67 \cdot 10^{-3}$ & & \\
\hline \multicolumn{3}{|c|}{ * all pin samples are from SKF bearings } & & \\
\hline & flat & $\mathrm{d}=47 \cdot 10^{-3}$, thickness $=7 \cdot 10^{-3}$ & & $\sim 1000 \mathrm{HV}$ \\
\hline
\end{tabular}

The contacts were realized by pressing the pins against a flat specimen, being characterized by the following initial contact parameters:

Table 5.2 Initial Hertzian contact parameters (see appendix A).

\begin{tabular}{|c|c|c|c|c|}
\hline Contact & $\begin{array}{c}\text { Load } \\
{[\mathrm{N}]}\end{array}$ & $\begin{array}{c}\text { Contact area dimensions } \\
{[\mathrm{m}]}\end{array}$ & $\begin{array}{c}\text { Mean contact } \\
\text { pressure [MPa] }\end{array}$ & $\begin{array}{c}\text { Maximum contact } \\
\text { pressure [MPa] }\end{array}$ \\
\hline Line & 15 & $\mathrm{~b}=6.41 \cdot 10^{-6}, \mathrm{~B}=8 \cdot 10^{-3}$ & 146.3 & 186.3 \\
\hline Point & 15 & $\mathrm{r}=78.5 \cdot 10^{-6}$ & 774.8 & 986.5 \\
\hline Elliptical & 10 & $\mathrm{a}=85.1 \cdot 10^{-6}, \mathrm{~b}=69.3 \cdot 10^{-6}$ & 539.4 & 809.2 \\
\hline
\end{tabular}

Table 5.3 Lubricants properties.

\begin{tabular}{|c|c|c|c|c|c|c|c|}
\hline & Units & Method & $\begin{array}{l}\text { Esso } \\
\text { EZL } \\
799 *\end{array}$ & Method & $\begin{array}{c}\text { Shell } \\
\text { HVI } \\
60^{* *} \\
\end{array}$ & Method & $\begin{array}{c}\text { Shell } \\
\text { Vitrea } \\
150^{* * *}\end{array}$ \\
\hline $\begin{array}{l}\text { viscosity } \\
\text { grad }\end{array}$ & - & & - & & - & $\begin{array}{l}\text { ISO } \\
3448\end{array}$ & 150 \\
\hline $\begin{array}{c}\text { Kinematic } \\
\text { viscosity } \\
400 \mathrm{C} \\
1000 \mathrm{C}\end{array}$ & $\mathrm{mm}^{2} / \mathrm{s}$ & $\begin{array}{c}\text { ASTM D } \\
445\end{array}$ & $\begin{array}{c}39 \\
8\end{array}$ & $\begin{array}{c}\text { ASTM D } \\
445\end{array}$ & $\begin{array}{c}25 \\
4.4-4.9\end{array}$ & D 445 & $\begin{array}{l}148 \\
14.5\end{array}$ \\
\hline $\begin{array}{c}\text { Viscosity } \\
\text { index }\end{array}$ & - & $\begin{array}{c}\text { ASTM D } \\
165 \\
\end{array}$ & 182 & $\begin{array}{c}\text { ASTM D } \\
2270 \\
\end{array}$ & 95 & D 2270 & 95 \\
\hline $\begin{array}{c}\text { Density at } \\
15^{\circ} \mathrm{C}\end{array}$ & $\mathrm{kg} / \mathrm{m}^{3}$ & $\begin{array}{l}\text { ASTM D } \\
4052\end{array}$ & 860 & - & 862 & $\begin{array}{c}\text { ISO } \\
12185\end{array}$ & 882 \\
\hline Flash point & ${ }^{0} \mathrm{C}$ & $\begin{array}{l}\text { ASTM D } \\
\quad 92\end{array}$ & 205 & $\begin{array}{c}\text { ASTM D } \\
93\end{array}$ & 202 & $\begin{array}{c}\text { ISO } \\
2592\end{array}$ & 243 \\
\hline Pour point & ${ }^{0} \mathrm{C}$ & - & - & $\begin{array}{c}\text { ASTM D } \\
97\end{array}$ & -15 & $\begin{array}{l}\text { ISO } \\
3016 \\
\end{array}$ & -9 \\
\hline $\begin{array}{c}\text { Total } \\
\text { acidity }\end{array}$ & $\begin{array}{c}\mathrm{mg} \\
\mathrm{KOH} / \mathrm{g}\end{array}$ & $\begin{array}{c}\text { ASTM D } \\
664 \\
\end{array}$ & 0.5 & $\begin{array}{c}\text { ASTM D } \\
974 \\
\end{array}$ & 0.05 & - & - \\
\hline $\begin{array}{c}\text { Ash } \\
\text { content }\end{array}$ & wt $\%$ & - & - & $\begin{array}{c}\text { ASTM D } \\
482\end{array}$ & 0.01 & D 524 & 0.23 \\
\hline
\end{tabular}

* Esso lubricants **www.pertmina.com *** www.shell-lubricants.com 
All tests (wear and friction) were performed at room temperature $20-25^{\circ} \mathrm{C}$ and for each contact three different lubricants were used (see lubricants characteristics Table 5.3).

\subsection{Experimental procedure}

To observe the change in friction due to wear, the next experimental procedure was followed (see Figure 5.4). Before starting the experiments, both samples (pin and flat) were cleaned in an ultrasonic bath (isopropanol) for 5 minutes and surface topography measurements were performed using an interference microscope. Each experimental test contains 2 steps.

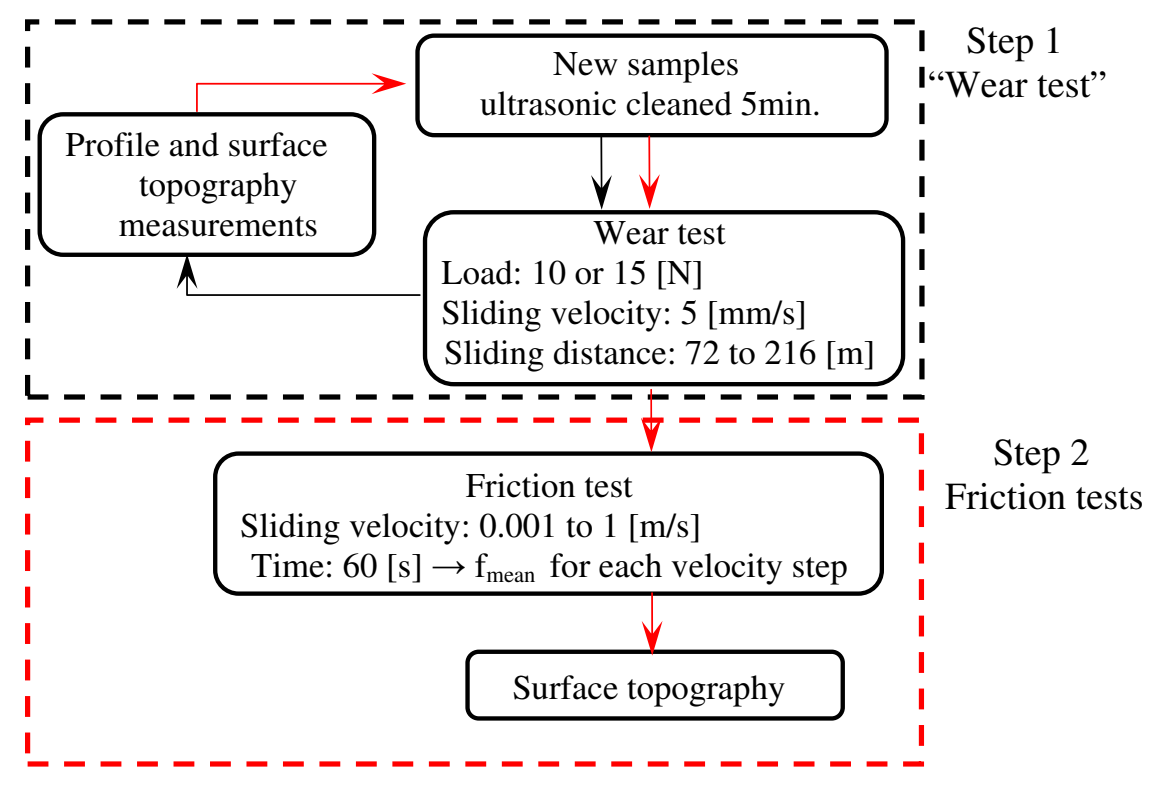

Figure 5.4 Experimental procedure used for obtaining a Stribeck curve.

The first step is a "wear test", conducted in order to generate a wear scar at the pin. For that the system runs for different sliding distances $(72,144$ and $216 \mathrm{~m})$ at the same sliding velocity $(0.005 \mathrm{~m} / \mathrm{s})$, temperature $\left(20-25{ }^{\circ} \mathrm{C}\right)$ and load $(15 \mathrm{~N})$. For each experiment a new combination of samples (pin and flat) were used. After the "wear test" both samples were cleaned in an ultrasonic bath and the surface topography of the pin was measured. 
In the second step the friction coefficient of the worn lubricated contact was determined by changing the velocity. To have a continuous lubricant flow in the contact at high velocities a pomp was used to direct the lubricant in the inlet region of the contact (see Figure 5.5).

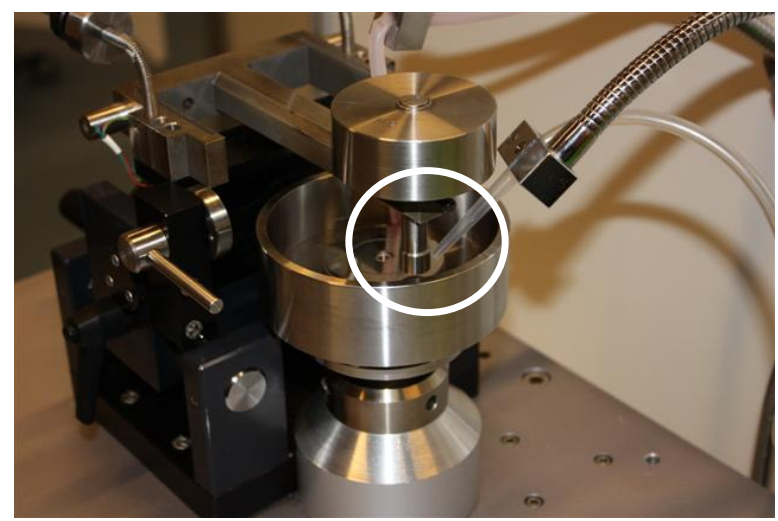

Figure 5.5 System to achieve a continuous oil flow during the experiments.

The Stribeck diagram is measured by varying the sliding velocity from 0.001 to 1 $\mathrm{m} / \mathrm{s}$ and for each value of the velocity the friction was measured for 1 minute (the steady state value of the friction is recorded).

After the second step the samples were cleaned ultrasonically for 5 minutes, using again isopropanol. The surface of the samples was studied to determine the size of the wear scar and the surface topography in the wear scar.

\subsection{Results}

The goal of these experiments is to observe the effect of wear on the different parameters involved in a lubricated tribosystem. Using the experimental procedure discussed in the previous section and the aforementioned testing conditions, the evolution of contact area, pin profile geometry and friction due to wear for all types of contacts are obtained.

\subsubsection{Line contact results}

To observe the changes in pin profile geometry wear tests were carried out by changing the test parameters (wear time i.e. sliding distance) and keeping the same 
value of load $(15 \mathrm{~N})$ and sliding velocity $(0.005 \mathrm{~m} / \mathrm{s})$ so that the system operates in the boundary lubrication regime. For the other test parameters see Table 5.1 and 5.2 .

Increasing the running-in time of the samples the contact width (2Lw) increases from $12.8 \mu \mathrm{m}$ (Hertzian contact) to $270 \mu \mathrm{m}$ (after a 12 hours wear test) leading to an increase of the contact area and therefore a decrease in contact pressure (from 146.3 down to $6.9 \mathrm{MPa}$ ).

During the wear tests also the friction was recorded. At the start the system goes through a running-in period in which the coefficient of friction decreases and stabilizes to a steady state value of about 0.15 .

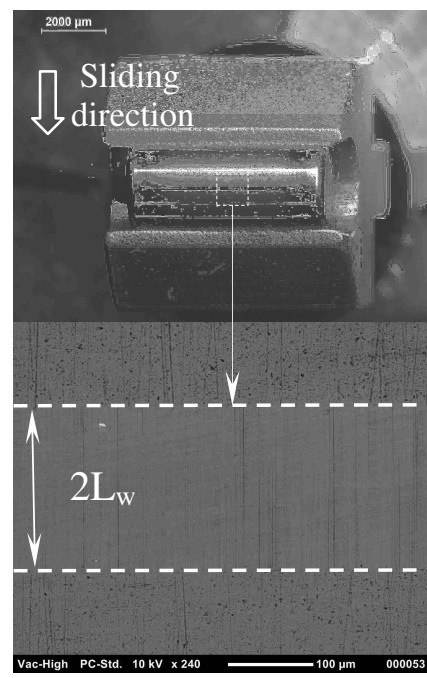

4 hours wear test

$2 \mathrm{~L}_{\mathrm{w}}=180 \mu \mathrm{m}$

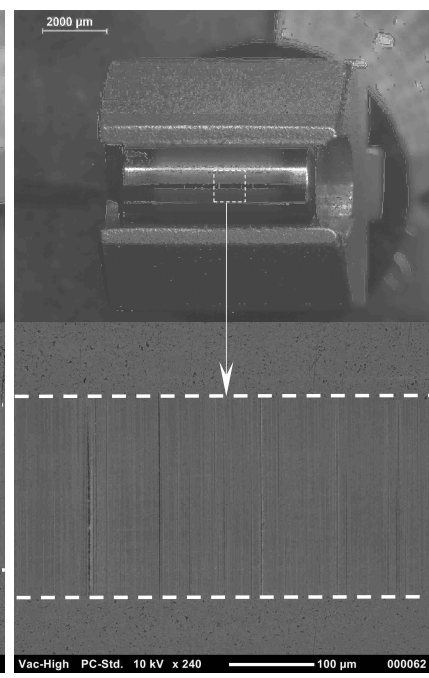

8 hours wear test

$2 \mathrm{~L}_{\mathrm{w}}=220 \mu \mathrm{m}$

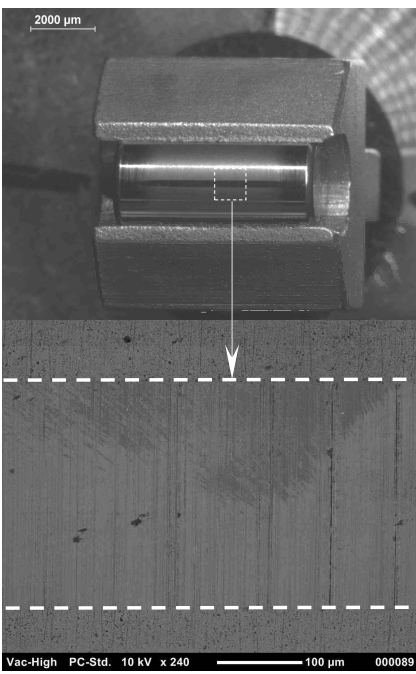

12 hours wear test

$2 \mathrm{~L}_{\mathrm{w}}=270 \mu \mathrm{m}$

Figure 5.6 Surface of the pin after wear tests, using Esso EZL 799 as a lubricant.

Changes in pin geometry due to wear were measured after each "wear test" by using the aforementioned interference microscope, evolution of the pin profile in sliding direction is presented in Figure 5.7. 


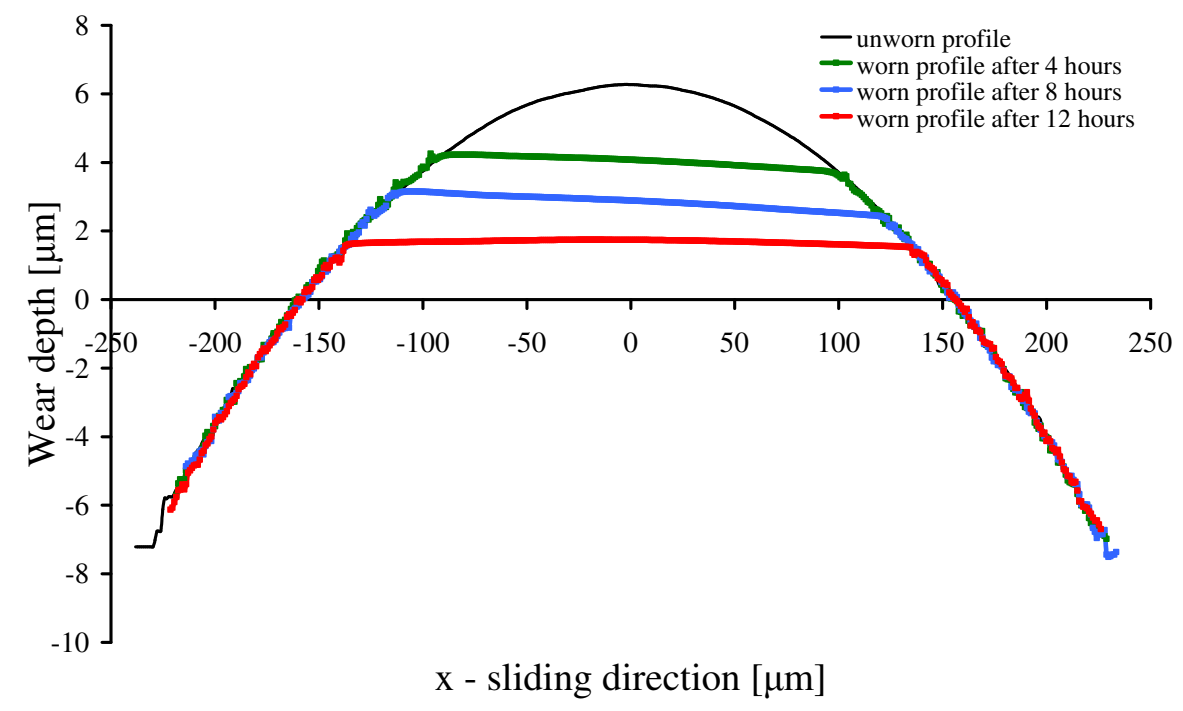

Figure 5.7 Evolution of the pin profile in sliding direction during "wear" tests.

The friction behaviour in worn lubricated sliding line contacts is investigated in the second step of the experimental procedure by measuring the Stribeck curve.

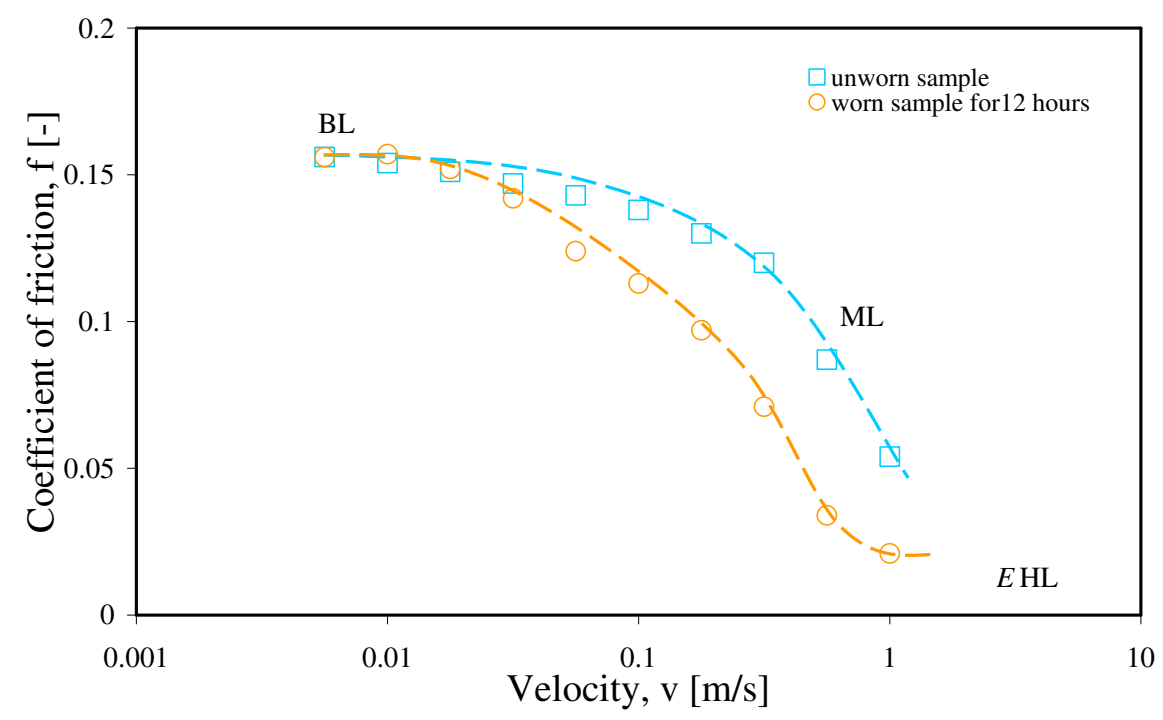

Figure 5.8 Experimental Stribeck curve of worn lubricated sliding line contacts, using Esso EZL 799 as a lubricant, test conditions see in Table 5.1 and 5.2. Markers are measurements and the dashed lines are curve fits. 
In Figure 5.8 the experimental results show that by increasing wear, friction decreases (shift of the Stribeck curve to left) which may lead to, for instance, a change of the operational regime of a system, from BL to ML. The wear scars after the friction tests are measured and pin profile geometries are compared with profiles from "wear" tests. The difference between profiles is insignificant which indicates that the pin profile hardly evolves during the friction measurements.

The experimental results for Esso EZL 799, Shell Vitrea 150 and Shell HVI 60 respectively are presented in Table 5.4.

Table 5.4 Test results from wear tests for the different lubricant used.

\begin{tabular}{|c|c|c|c|c|c|c|}
\hline Lubricant & $\begin{array}{c}\text { Time } \\
{[\mathrm{h}]}\end{array}$ & $\begin{array}{c}\text { Contact } \\
w i d t h, 2 \mathrm{~L}_{\mathrm{w}} \\
{[\mu \mathrm{m}]}\end{array}$ & $\begin{array}{c}\text { Wear depth } \\
\mathrm{w},[\mu \mathrm{m}]\end{array}$ & $\begin{array}{c}\text { Pressure } \\
{[\mathrm{MPa}]}\end{array}$ & $\begin{array}{c}\text { Wear rate } \\
{\left[\mathrm{mm}^{3} / \mathrm{N} \cdot \mathrm{m}\right]}\end{array}$ & $\begin{array}{c}\text { Roughness } \\
\sigma[\mathrm{m}]\end{array}$ \\
\hline \multirow{2}{*}{$\begin{array}{c}\text { Esso } \\
\text { EZL 799 }\end{array}$} & 4 & 180 & 2.1 & 10.4 & $7.1 \cdot 10^{-6}$ & $1.75 \cdot 10^{-7}$ \\
\cline { 2 - 7 } & 8 & 220 & 3.1 & 8.5 & $1.8 \cdot 10^{-6}$ & $1.69 \cdot 10^{-7}$ \\
\cline { 2 - 7 } & 12 & 270 & 4.5 & 6.9 & $2.0 \cdot 10^{-6}$ & $1.53 \cdot 10^{-7}$ \\
\hline \multirow{2}{*}{$\begin{array}{c}\text { Shell } \\
\text { Vitrea }\end{array}$} & 4 & 184 & 2.1 & 10.2 & $1.2 \cdot 10^{-6}$ & $6.46 \cdot 10^{-8}$ \\
\cline { 2 - 7 } 150 & 8 & 240 & 3.5 & 7.8 & $1.8 \cdot 10^{-6}$ & $6.45 \cdot 10^{-8}$ \\
\cline { 2 - 7 } & 12 & 260 & 3.9 & 7.2 & $4.7 \cdot 10^{-6}$ & $3.50 \cdot 10^{-8}$ \\
\hline Shell & 4 & 204 & 2.2 & 9.2 & $1.4 \cdot 10^{-5}$ & $6.98 \cdot 10^{-8}$ \\
HVI 60 & 8 & 224 & 2.9 & 8.4 & $3.5 \cdot 10^{-6}$ & $2.35 \cdot 10^{-7}$ \\
\cline { 2 - 7 } & 12 & 324 & 6.3 & 5.8 & $3.9 \cdot 10^{-6}$ & $1.89 \cdot 10^{-7}$ \\
\hline
\end{tabular}

For each wear test a wear rate value was calculated by determining the wear volume of the pin.

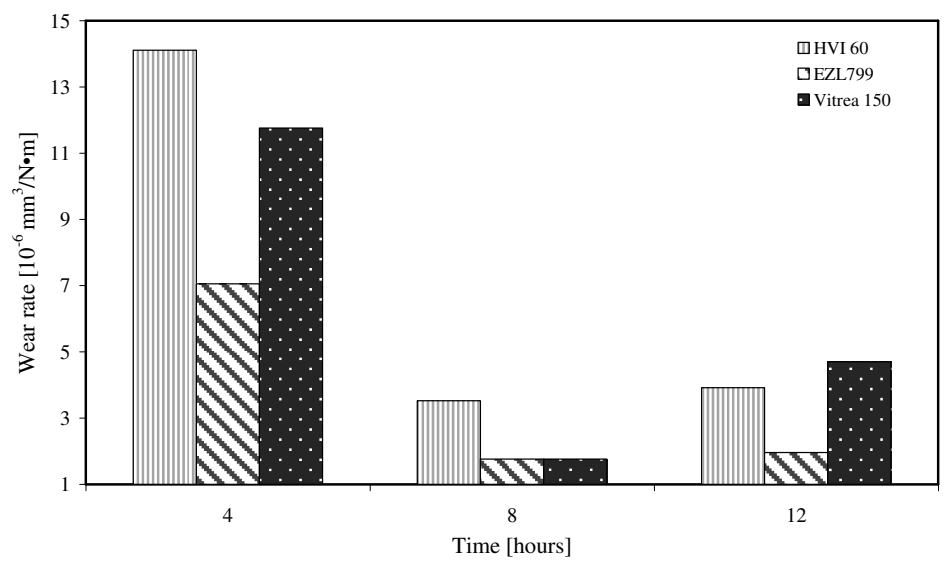

Figure 5.9 Evolution of the wear rate during wear tests for all lubricants. 
The experimental tests show that for Shell HVI 60 the highest values for the wear rate were obtained (see Figure 5.9) and for Esso EZL 799 the lowest values, the evolution of wear in lubricated contacts depends largely on the lubricant type (chemical composition) used.

\subsubsection{Point contact results}

Following the same steps of the experimental procedure as in the case of the line contact the influence of wear on friction in lubricated sliding point contacts has been investigated for the three lubricants. The test conditions are given in Table 5.1 and 5.2. The wear scars of the tested specimens were measured at the same magnification in order to easily compare the tests results.

In Figure 5.10 the worn surfaces are given. The wear scar diameter increases to 556 $\mu \mathrm{m}$ (after 12 hours wear test) and a steady state value of the coefficient of friction of about 0.14 is measured.

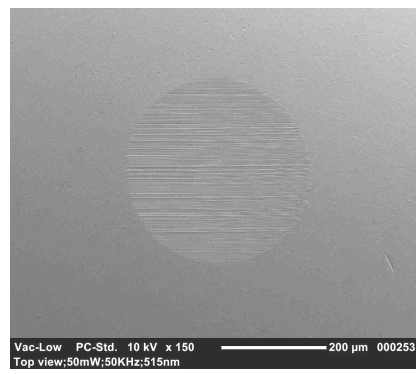

$\begin{array}{ll}2 \text { hours wear test } & 4 \text { hours wear test } \\ \mathrm{d}_{\text {scar }}=366 \mu \mathrm{m} & \mathrm{d}_{\text {scar }}=424 \mu \mathrm{m}\end{array}$

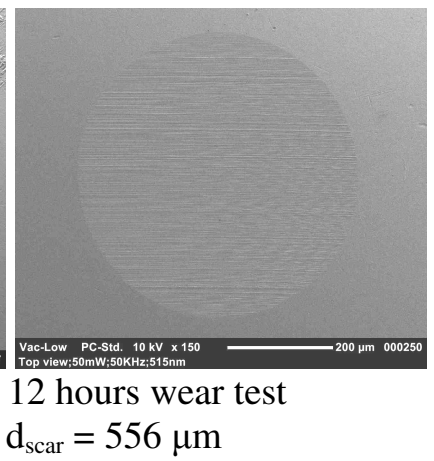

Figure 5.10 Surface of the pin after wear tests, using Esso EZL 799 as a lubricant.

In time wear leads to changes in contact geometry. The modifications in the pin profile were investigated by measuring the pin surfaces before and after the wear tests. In Figure 5.11 the evolution of the pin profile due to wear is presented.

The occurrence of wear in point contacts changes the contact geometry which leads to a decrease in contact pressure and as a result a change in hydrodynamic lubrication causing a change of the operation regime of the tribosystem (see Figure 5.12). 


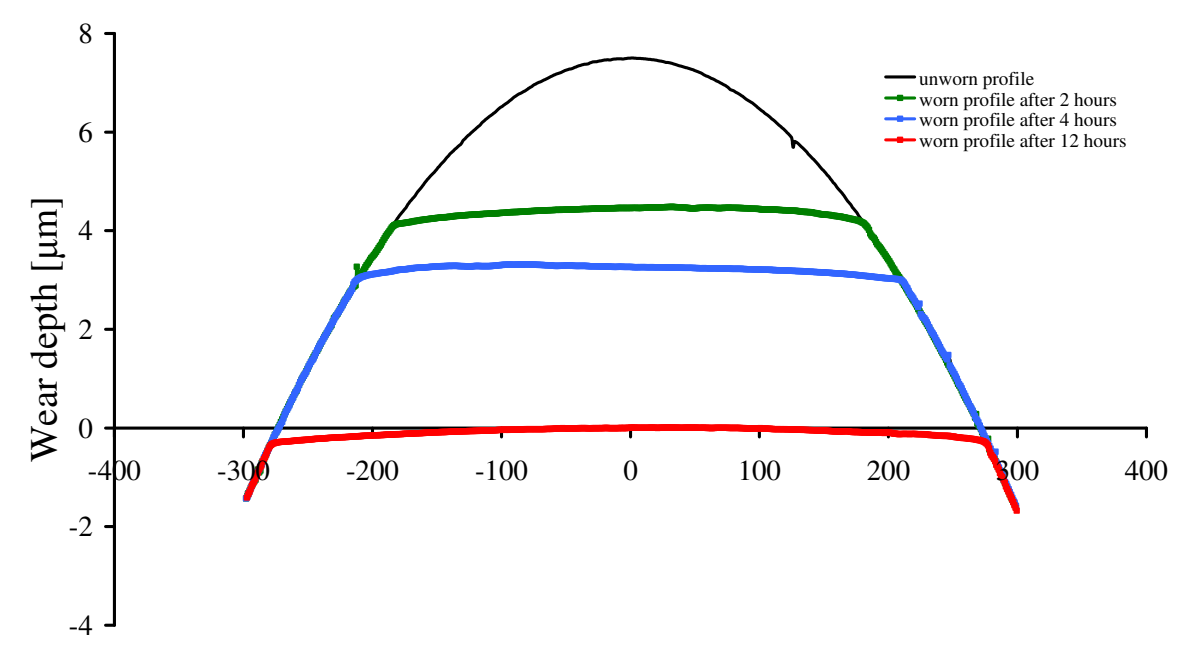

$\mathrm{x}$ - sliding direction $[\mu \mathrm{m}]$

Figure 5.11 Evolution of the pin profile in sliding direction during wear tests.

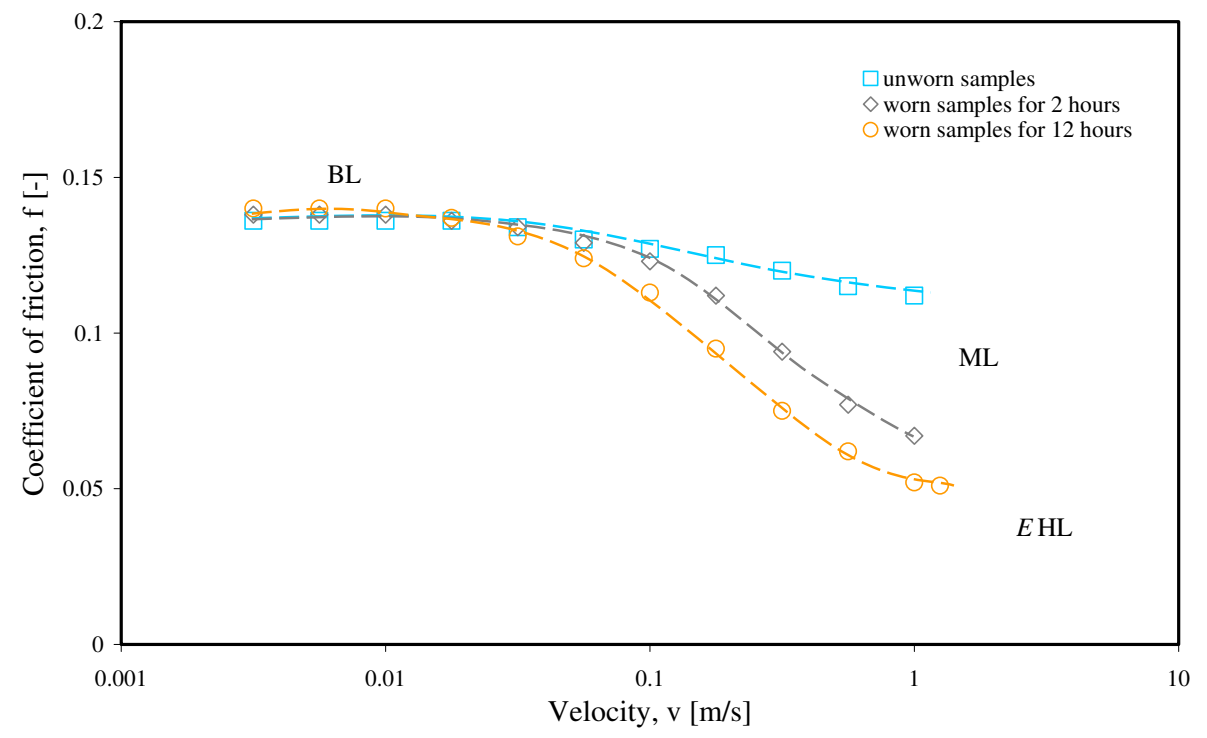

Figure 5.12 Experimental Stribeck curve of worn lubricated sliding point contacts, using Esso EZL 799 as a lubricant.

The friction level in the (E)HL regime drops significantly due to the fact that the lubricant behaviour, at this pressure and temperature level, changes from solid state 
to liquid state behaviour [1]. After the friction tests the pin profiles are measured and compared with the profiles from wear tests.
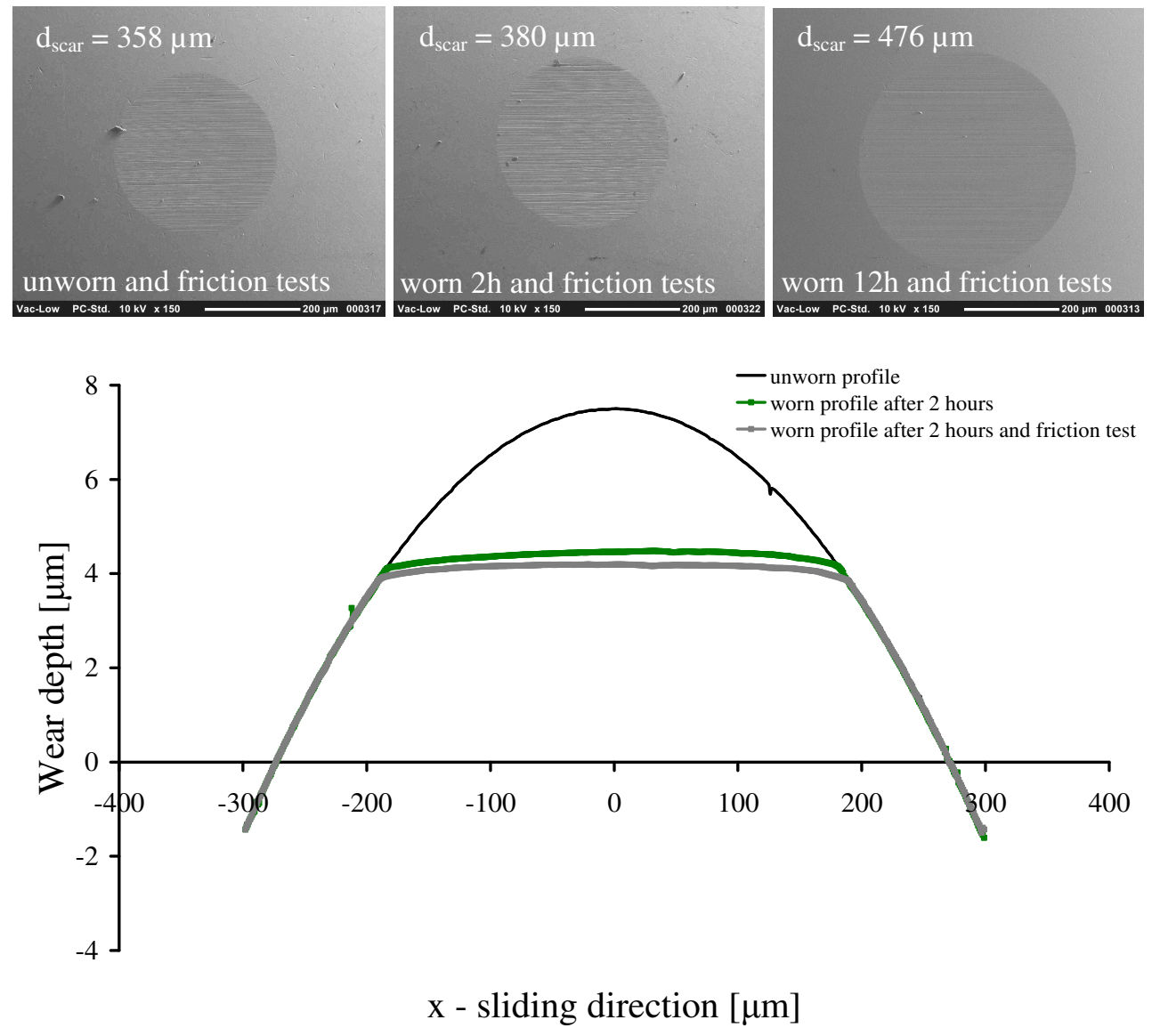

Figure 5.13 Pin profile geometry after wear and friction tests, using Esso EZL 799 as a lubricant.

The experimental results for Esso EZL 799, Shell Vitrea 150 and Shell HVI 60 respectively are presented in Table 5.5.

As for the line contact, the wear rate values of the point contact wear tests were calculated based on volume loss of the pin during wear tests. Based on data from Figure 5.14 it is observed that when using Shell HVI 60 as a lubricant wear reaches the highest values for each of the wear tests and the lowest values are recorded for Esso EZL 799. 
Table 5.5 Contact parameters from wear tests for all lubricants.

\begin{tabular}{|c|c|c|c|c|c|c|}
\hline Lubricant & $\begin{array}{c}\text { Time } \\
{[\mathrm{h}]}\end{array}$ & $\begin{array}{c}\text { Wear scar } \\
2 \mathrm{~L}_{\mathrm{w}},[\mu \mathrm{m}]\end{array}$ & $\begin{array}{c}\text { Wear } \\
\text { depth } \\
\mathrm{w},[\mu \mathrm{m}]\end{array}$ & $\begin{array}{c}\text { Pressure } \\
{[\mathrm{MPa}]}\end{array}$ & $\begin{array}{c}\text { Wear rate } \\
{\left[\mathrm{mm}^{3} / \mathrm{N} \cdot \mathrm{m}\right]}\end{array}$ & $\begin{array}{c}\text { Roughness } \\
\sigma[\mathrm{m}]\end{array}$ \\
\hline \multirow{2}{*}{$\begin{array}{c}\text { ESso } \\
\text { EZL 799 }\end{array}$} & 2 & 366 & 3.04 & 142.6 & $7.1 \cdot 10^{-6}$ & $6.9 \cdot 10^{-8}$ \\
\cline { 2 - 7 } & 4 & 424 & 4.26 & 106.2 & $4.7 \cdot 10^{-6}$ & $1.1 \cdot 10^{-7}$ \\
\cline { 2 - 7 } & 12 & 556 & 7.5 & 61.8 & $1.6 \cdot 10^{-6}$ & $6.8 \cdot 10^{-8}$ \\
\hline \multirow{2}{*}{$\begin{array}{c}\text { Shell } \\
\text { Vitrea }\end{array}$} & 2 & 346 & 3.4 & 159.5 & $9.4 \cdot 10^{-6}$ & $7.7 \cdot 10^{-8}$ \\
\cline { 2 - 7 } 150 & 4 & 572 & 6 & 58.4 & $3.5 \cdot 10^{-6}$ & $6.4 \cdot 10^{-8}$ \\
\cline { 2 - 7 } & 12 & 635 & 9.7 & 47.4 & $2.3 \cdot 10^{-6}$ & $9.2 \cdot 10^{-8}$ \\
\hline Shell & 2 & 448 & 4.7 & 95.2 & $1.4 \cdot 10^{-5}$ & $8.9 \cdot 10^{-8}$ \\
\cline { 2 - 7 } HVI 60 & 4 & 568 & 7.5 & 59.2 & $4.7 \cdot 10^{-6}$ & $9.1 \cdot 10^{-8}$ \\
\cline { 2 - 7 } & 12 & 748 & 13 & 34.1 & $2.3 \cdot 10^{-6}$ & $8.8 \cdot 10^{-8}$ \\
\hline
\end{tabular}

The point contact results are in line with the results obtained with line contact wear measurements.

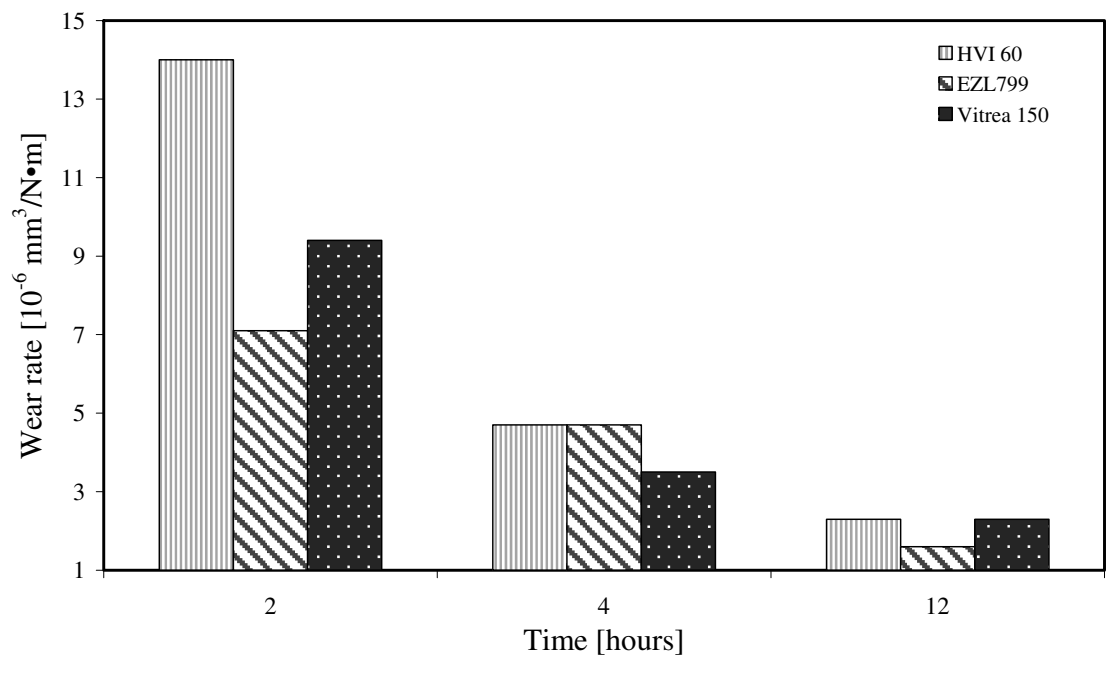

Figure 5.14 Evolution of the wear rate during wear test for all lubricants.

\subsubsection{Elliptical contact results}

The contact between a spherical roller (21305CC SKF bearing) and a flat is used (see pin geometry from Table 5.1) to study the effect of wear on friction in 
elliptical contacts. The influence of wear on friction in elliptical contact was investigated by applying the same experimental procedure (10 N load) using Esso EZL 799 as lubricant and increasing the running time of the samples to 40 hours. For the test conditions the reader is referred to Table 5.1 and 5.2. During the wear tests the friction coefficient reaches a steady state value of about 0.14 .
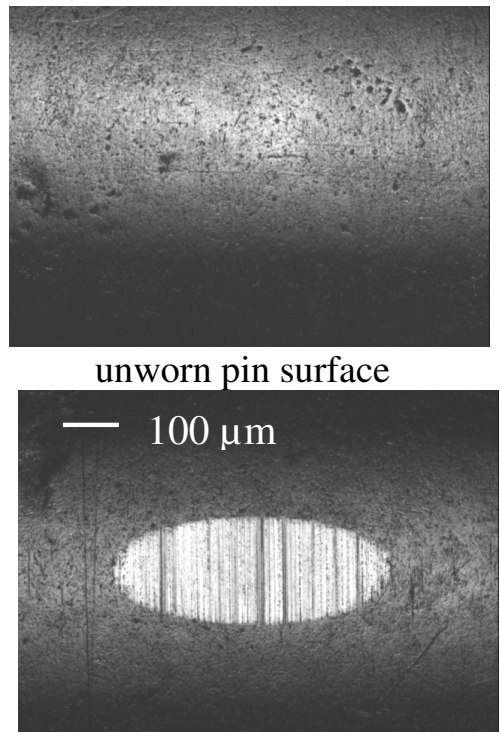

worn pin after $16 \mathrm{~h}$ wear test and friction test

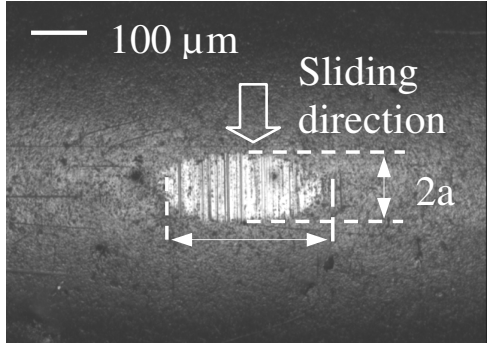

worn pin after $8 \mathrm{~h}$ wear test and friction test

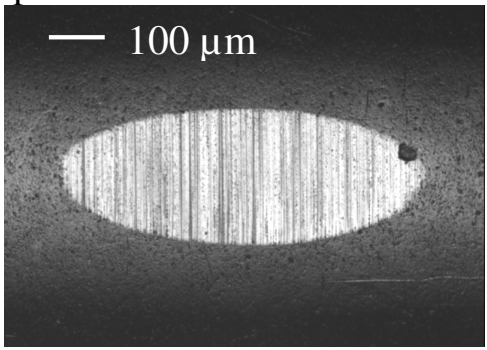

worn pin for $40 \mathrm{~h}$ wear test and friction test

Figure 5.15 Pin surface after wear and friction tests, using Esso EZL 799 as a lubricant.

In the case of the elliptical contact the same evolution of contact parameters like in the other two contacts mentioned above has been found.

Table 5.6 Contact parameters after friction tests.

\begin{tabular}{|c|c|c|c|c|c|}
\hline Lubricant & $\begin{array}{c}\text { Time } \\
{[\mathrm{h}]}\end{array}$ & $\begin{array}{c}\text { Wear scars } \\
\text { dimensions }[\mu \mathrm{m}]\end{array}$ & $\begin{array}{c}\text { Pressure } \\
{[\mathrm{MPa}]}\end{array}$ & $\begin{array}{c}\text { Wear rate } \\
{\left[\mathrm{mm}^{3 /} \mathrm{N} \cdot \mathrm{m}\right]}\end{array}$ & $\begin{array}{c}\text { Roughness } \\
\sigma[\mathrm{m}]\end{array}$ \\
\hline \multirow{2}{*}{ Esso } & 8 & $2 \mathrm{a}=170 ; 2 \mathrm{~b}=375$ & 199.7 & $1.6 \cdot 10^{-8}$ & $7.8 \cdot 10^{-8}$ \\
\cline { 2 - 6 } & 16 & $2 \mathrm{a}=270 ; 2 \mathrm{~b}=650$ & 72.6 & $6.3 \cdot 10^{-8}$ & $6.3 \cdot 10^{-8}$ \\
\cline { 2 - 7 } & 40 & $2 \mathrm{a}=340 ; 2 \mathrm{~b}=840$ & 44.6 & $6.9 \cdot 10^{-8}$ & $5.2 \cdot 10^{-8}$ \\
\hline
\end{tabular}

By increasing the running time of the tribosystem, the components contact geometry changes leading to a decrease in contact pressure which can be 
considered to be the main cause of the change in frictional behaviour of a lubricated system (the decrease in friction from Figure 5.16 results in a shift of the Stribeck curve to the left).

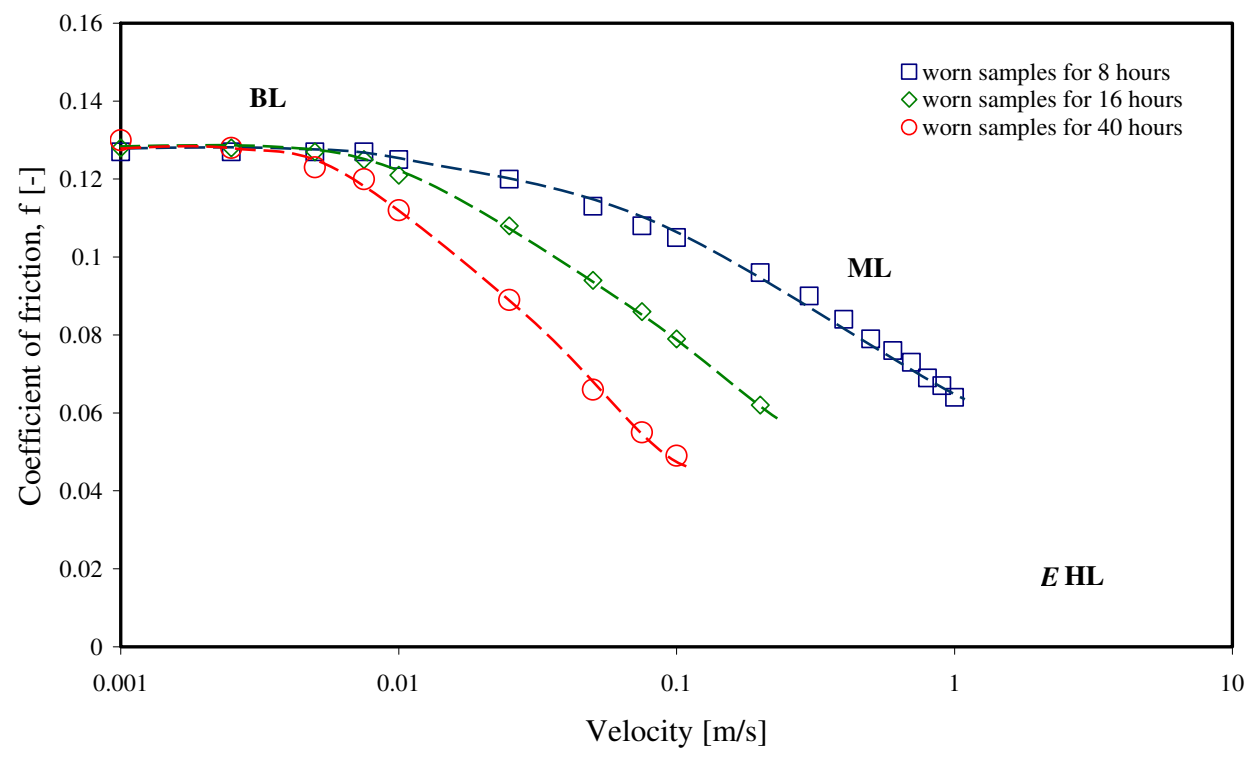

Figure 5.16 Experimental Stribeck curve of a worn lubricated sliding elliptical contact, using Esso EZL 799 as a lubricant.

These results shown in Table 5.6 and Figure 5.16 clearly indicate that the shift of the Stribeck curve is not caused by a change in the surface roughness. The roughness varies by approximately $25 \%$ and cannot cause a shift of one decade [2] and [3].

\subsection{Conclusions}

In this chapter the influence of wear on friction in lubricated concentrated contact was experimentally investigated. By changing the operational test parameters and following an experimental procedure the evolution of the contact geometry and friction due to wear were measured.

All wear tests show that by increasing the running time the contact area (wear scars) increases and by that a drop in the contact pressure occurs. The rate of change in contact geometry depends on the type of lubricant used (for all contacts Shell HVI 60 gave the highest values in wear rate). Depending on the chemical compounds 
(additive package) and test conditions some lubricants may form protected layers on the surface whose role is to protect them against wear and extend the lifetime of tribosystems.

The second step of the experimental procedure (friction tests) shows that by increasing wear in the contact the level of friction drops, resulting in a shift of the Stribeck curve to the left, having as main effect that the tribosystem may operate in another lubrication regime (for example: from BL to ML). The significant change in friction is caused by a rather small amount of wear, i.e. a few $\mu \mathrm{m}$ wear depth. The friction results will be used in chapter 6 for validation of the theoretical results from the mixed lubrication friction model.

\subsection{References}

[1] Alsaad, M., Bair, S., Sanborn, D.M. and Winer, W.O., "Glass transitions in lubricants: its relation to elastohydrodynamic lubrication (EHL)", ASME JOLT, Vol. 100, 1978, pp. 404-417.

[2] Gelinck, E., "Mixed Lubrication of line contacts", PhD thesis, University of Twente, The Netherlands, 1999, pp. 56-59.

[3] Faraon, I., "Mixed lubricated line contacts", $\mathrm{PhD}$ thesis, University of Twente, The Netherlands, 2005, pp. 46-48. 


\section{Chapter 6 Validation}

\subsection{Introduction}

This chapter includes a comparison of some of the experimental results of the concentrated contacts presented in chapter 5 and the friction model presented in chapter 4. Using as inputs: operational parameters, lubricant rheological properties, surface topography and contact geometry of the worn contacts in the mixed lubrication friction model, the coefficient of friction corresponding to each lubrication regime is calculated and presented in the Stribeck curves.

\subsection{Line contact}

Stribeck curve simulations for worn lubricated line contacts involve the use of the worn surface topography (after friction tests). Examples of the evolution of the pin surface during different stages of testing are shown in Figure 6.1 and 6.2.

a)

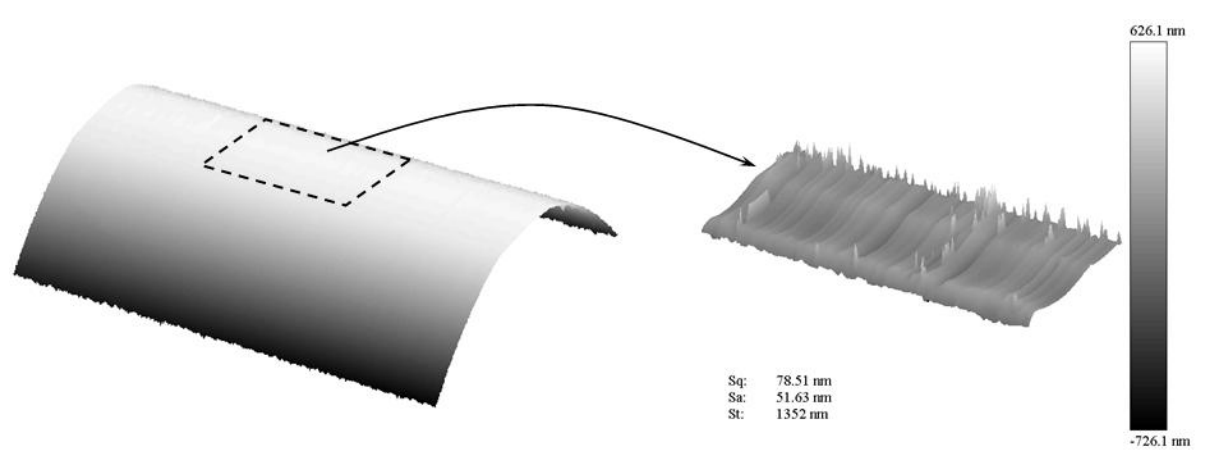


b)

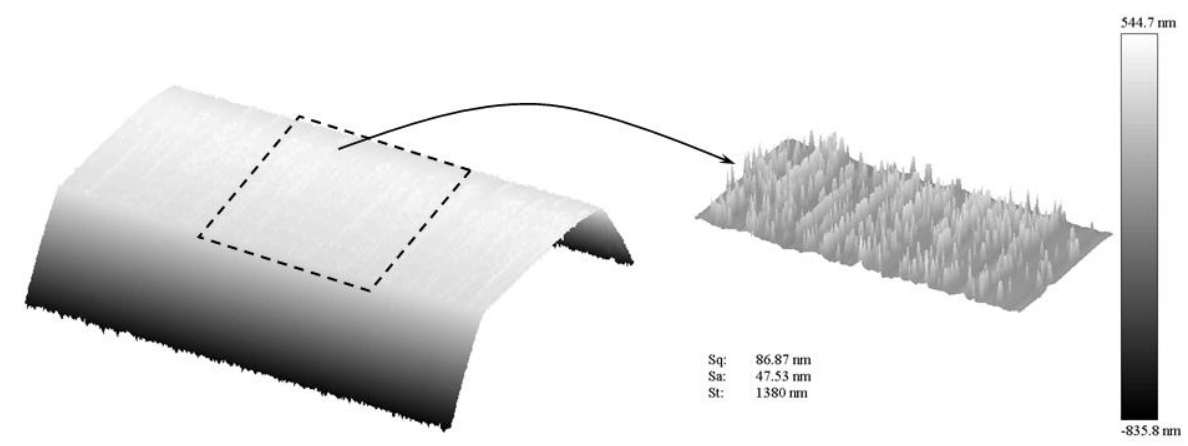

Figure 6.1 Surface topography of lubricated line contacts using Esso EZL 799 as a lubricant: a) surface after friction test, $b$ ) surface after $12 \mathrm{~h}$ running-in and friction test. The $R_{a}$ is of the order of $0.05 \mu \mathrm{m}$.

a)

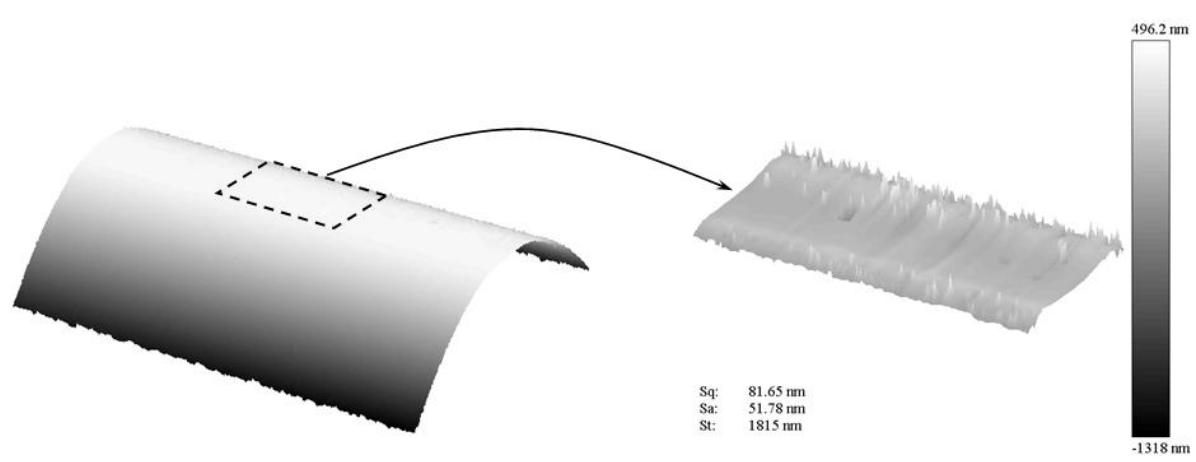

b)

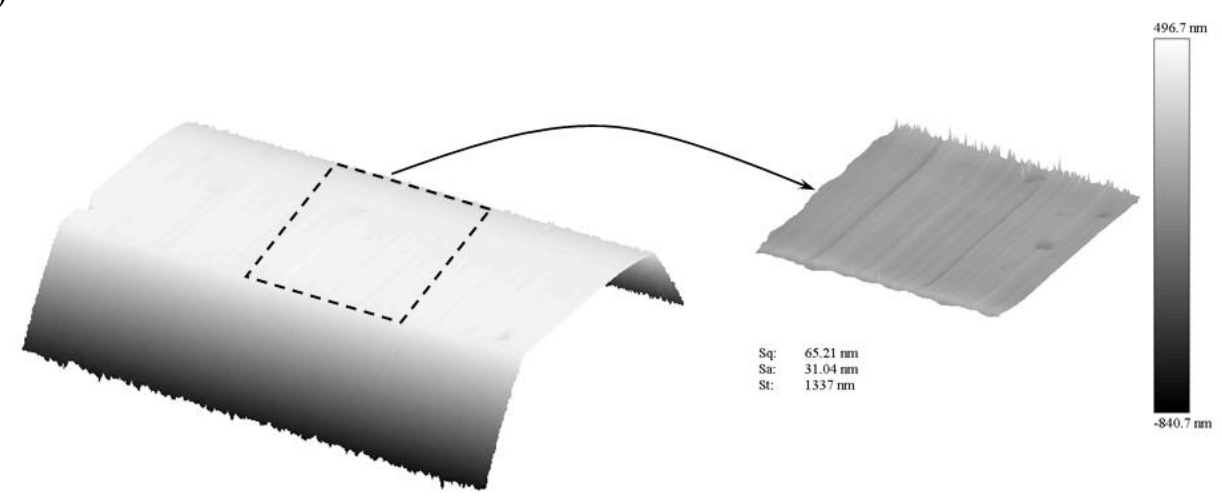

Figure 6.2 Surface topography of lubricated line contacts using Shell Vitrea 150 as a lubricant: a) surface after friction test, $b$ ) surface after a $12 \mathrm{~h}$ running-in and friction test. The $R_{a}$ is of the order of $0.04 \mu \mathrm{m}$. 


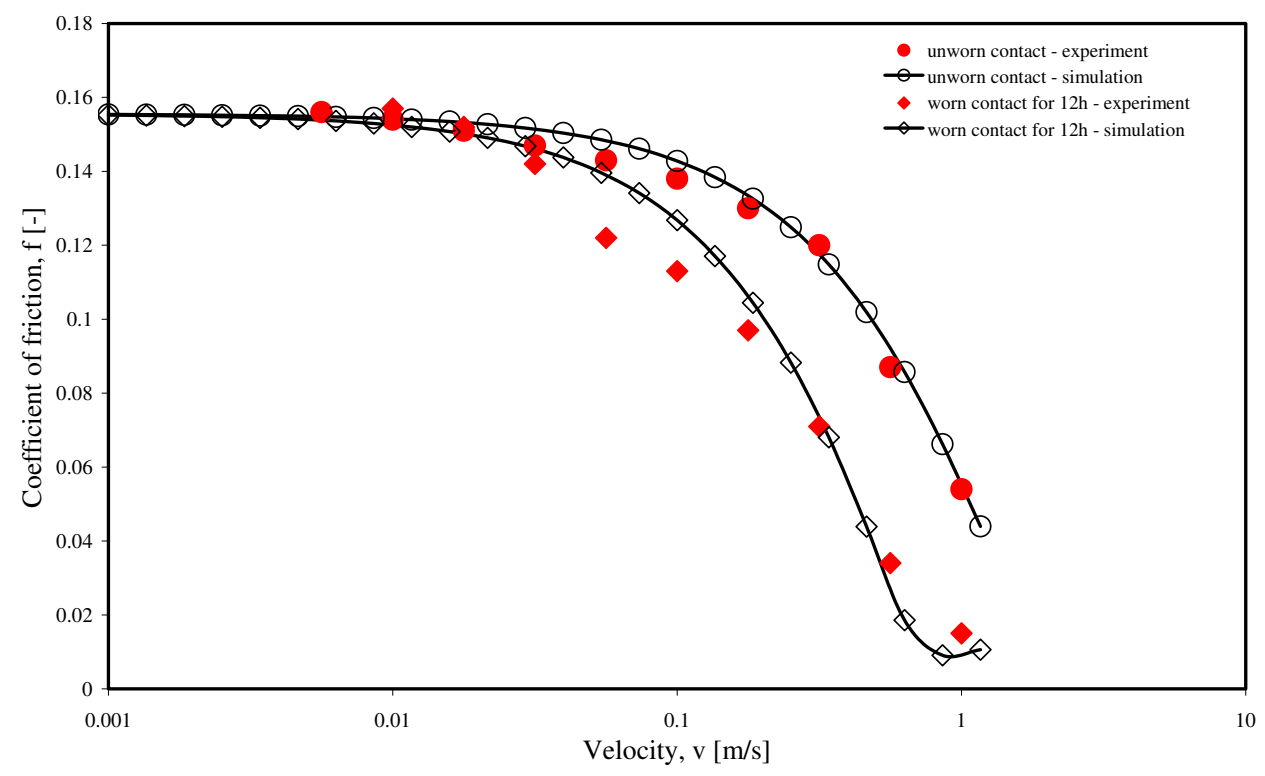

Figure 6.3 Comparison between experimental results (chapter 5) and simulation for a worn lubricated line contact using Esso EZL 799 as a lubricant.

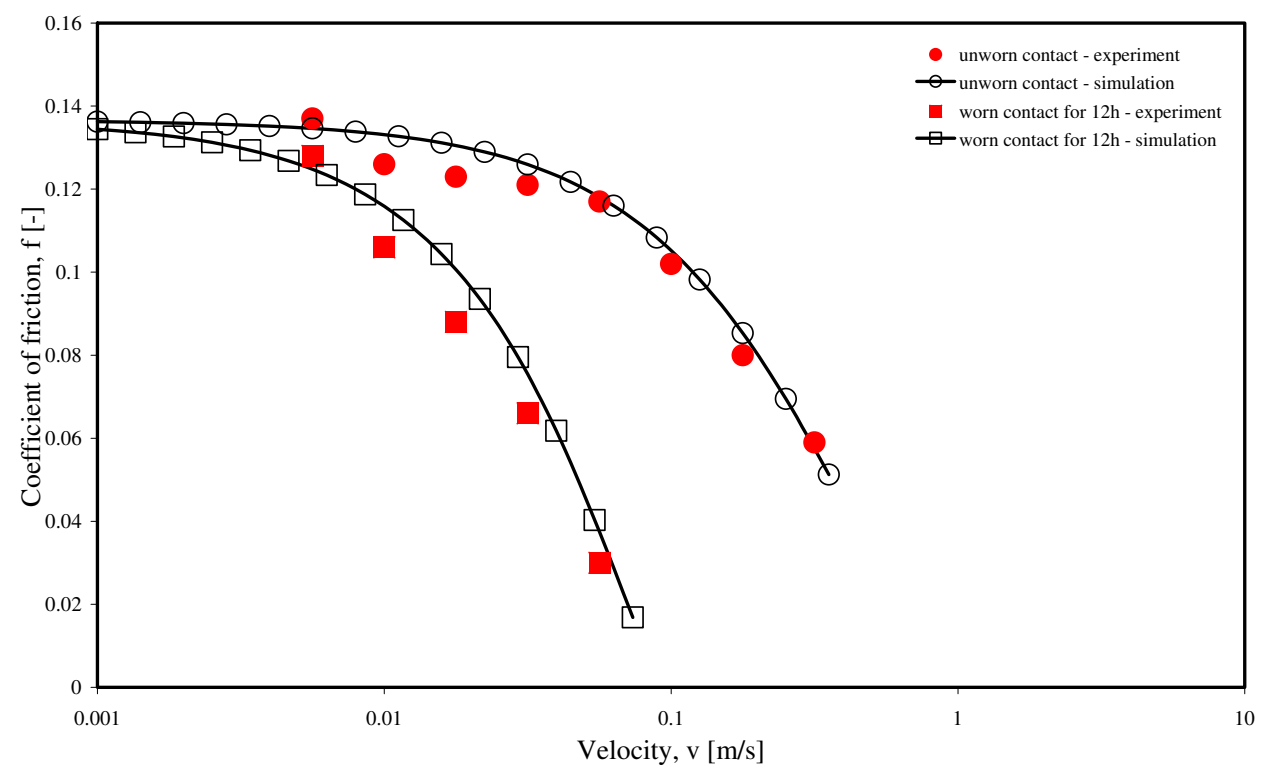

Figure 6.4 Comparison between experimental results (chapter 5) and simulation for a worn lubricated line contact using Shell Vitrea 150 as a lubricant. 
Comparison between the measured Stribeck curve and the simulation using the mixed lubrication friction model shows good agreement see Fig. 6.3 and 6.4. The values as input for the friction model are given in Appendix D: Table D.5 for simulations from Figure 6.3 respectively Table D.6 for Figure 6.4.

Although the wear depth is of the order of a few micrometers the effect on friction when it operates in the ML regime is significant. The theoretical and experimental results show that wear facilitates hydrodynamic action (an increase in separation between tested samples due to change in contact geometry) in lubricated line contacts.

\subsection{Point and elliptic contact}

Input data from section 5.5.2 respectively 5.5.3 are used for the deterministic mixed lubrication friction model to simulate the friction in worn lubricated point and elliptical contacts.

a)

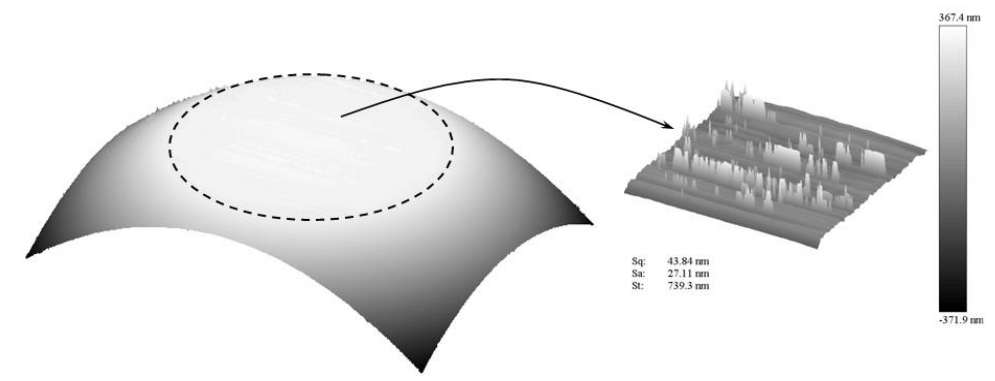

b)

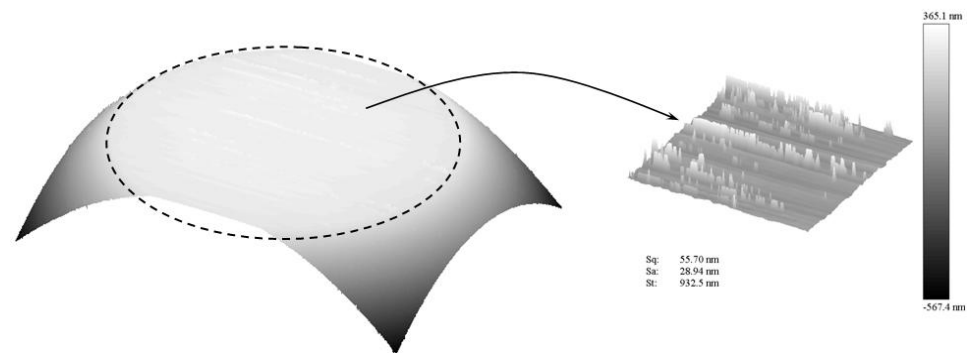

Figure 6.5 Surface topography of lubricated point contact using Esso EZL 799 as a lubricant: a) surface after $2 \mathrm{~h}$ running-in and friction test, $b$ ) surface after $12 \mathrm{~h}$ running-in and friction test. $R_{a}$ is of the order of $0.03 \mu \mathrm{m}$. 
Examples of worn surfaces topography after friction test (Stribeck curve) for a point contact are shown in the Figure 6.5.

The input parameters for the friction model are given in Table D.7 (see Appendix D). In Figure 6.6 the comparison between the measured and the calculated Stribeck curve using the deterministic mixed lubrication friction model in the case of a worn lubricated point contact using Esso EZL 799 as a lubricant are presented. The simulations show rather good agreement with the experimental results.

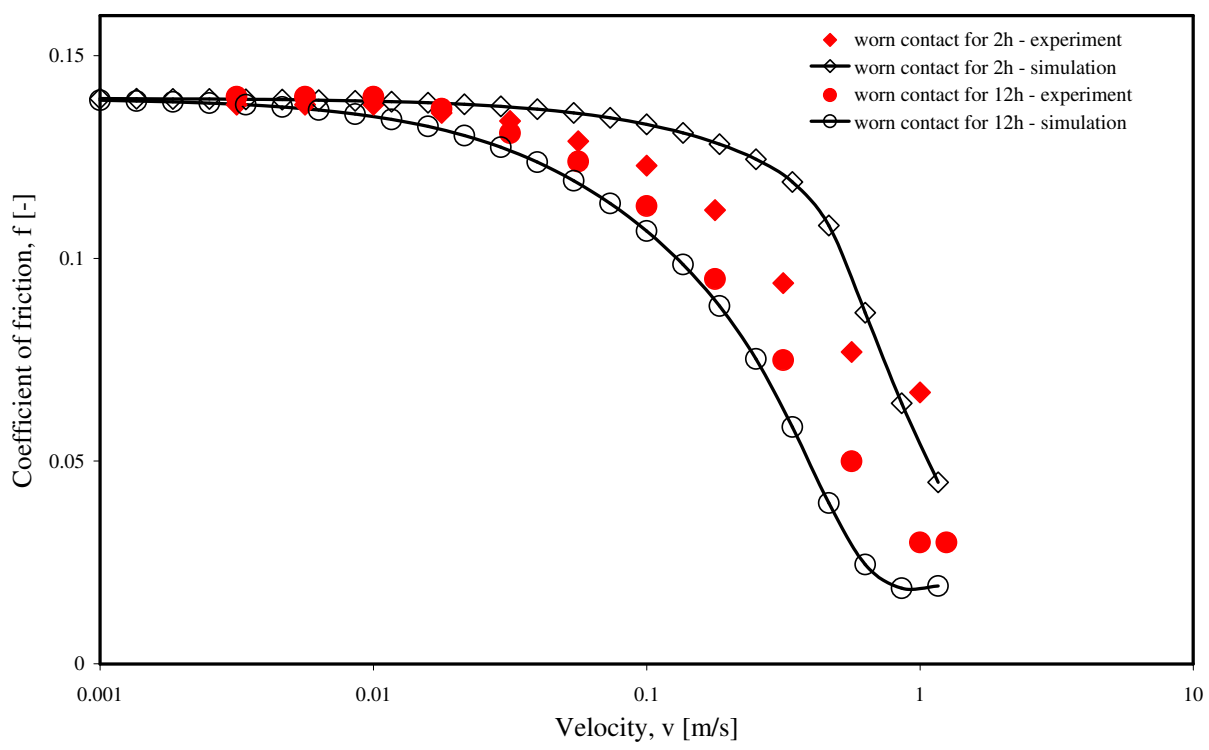

Figure 6.6 Comparison between experimental results (chapter 5) and simulation for a worn lubricated point contact using Esso EZL 799 as a lubricant.

a)

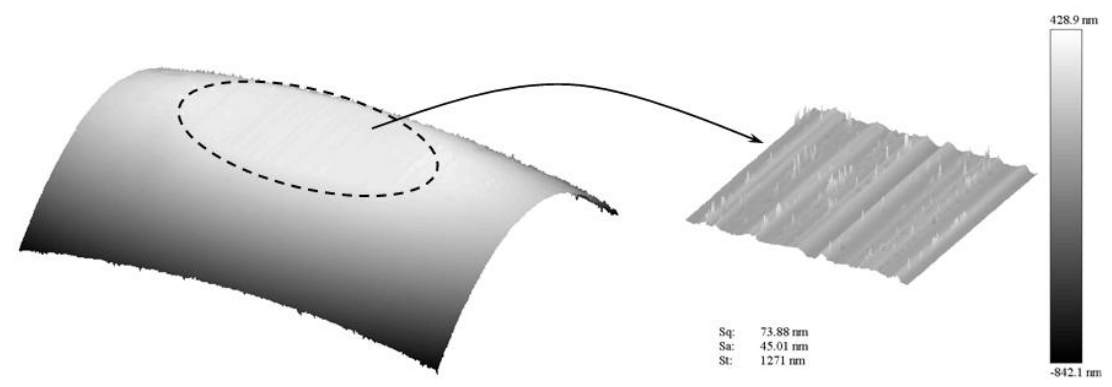


b)

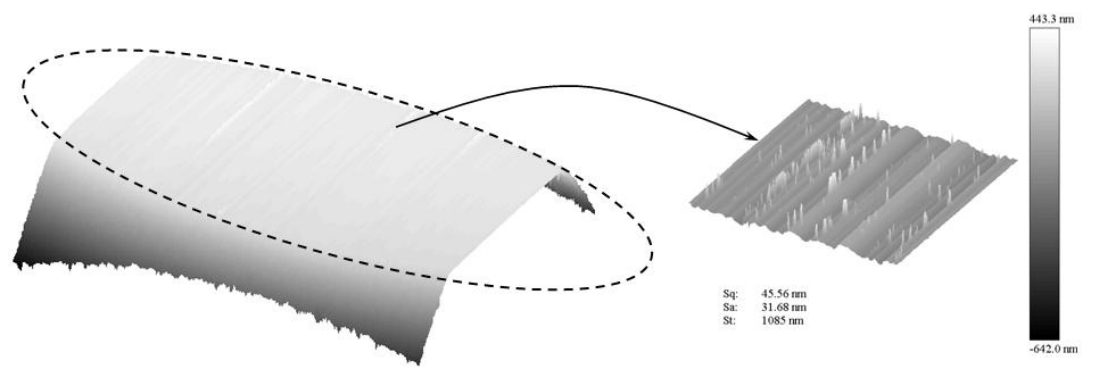

Figure 6.7 Surface topography of lubricated elliptic contact using Esso EZL 799 as a lubricant: a) surface after $8 \mathrm{~h}$ running-in and friction test, $b$ ) surface after $40 \mathrm{~h}$ running-in and friction test.

In Figure 6.8 the simulations for the first test (worn elliptic contact run for 8 hours) as well as the second test (contact running-in for 40 hours) show good agreement with the experimental results. The input parameters for the friction model are given in Table D.8 (see Appendix D).

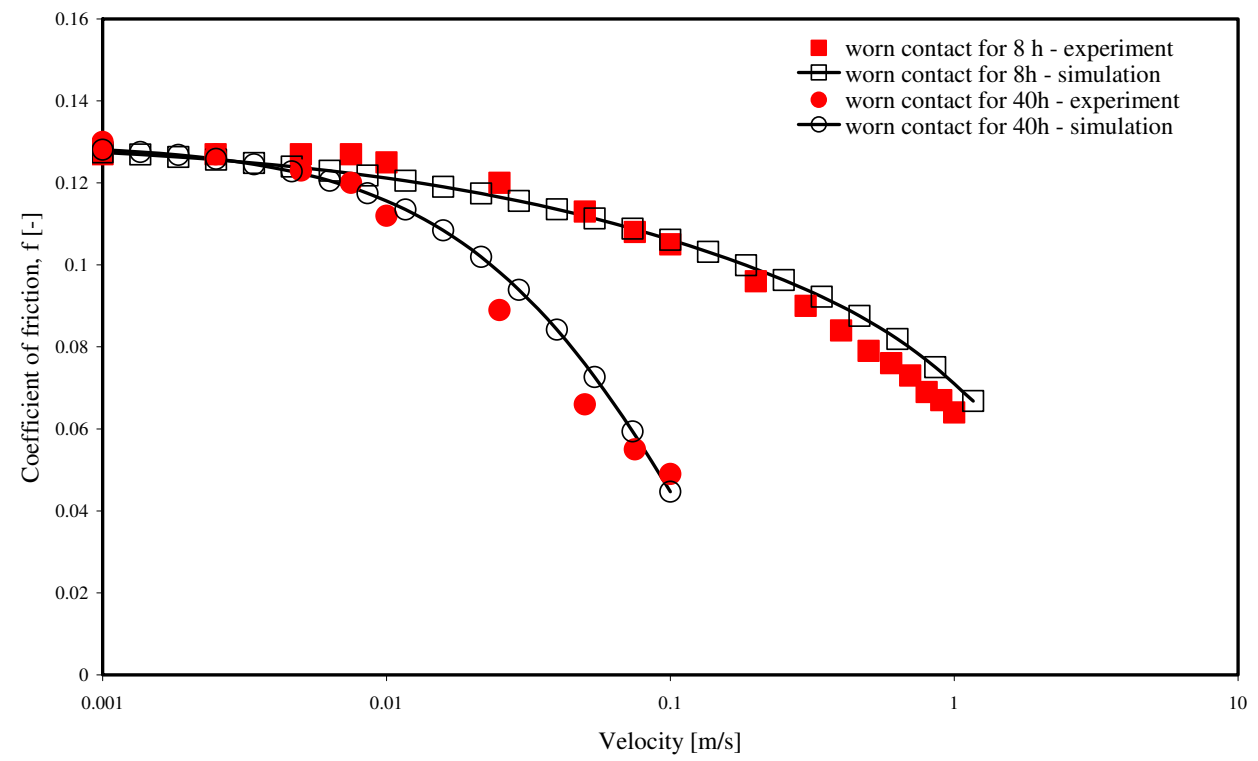

Figure 6.8 Comparison between experimental results (chapter 5) and simulation for a worn lubricated elliptical contact using Esso EZL 799 as a lubricant. 


\subsection{Conclusions}

This chapter presented a comparison between experimental results shown in chapter 5 and the simulation from the mixed lubrication friction model, chapter 4, for different types of contact.

The predicted Stribeck curves are in agreement with the experimental results, both show that by increasing wear in the contact, a decrease in friction (shift of the Stribeck curve to the left) and a modification in operational regime of a system is inevitable (example: from BL to ML). 


\section{Chapter 7 Evolution of the Stribeck curve in time}

\subsection{Introduction}

In previous chapters it was shown that in time due to wear lubricated contacting surfaces are changing both at micro and macro geometry level as a function of the operational parameters. In chapter 6 validation of the experimental measured Stribeck curves was presented using results from a mixed lubrication friction model (chapter 4) in which a minimum film thickness formula for worn concentrated contacts (chapter 3) was incorporated. In this chapter friction (Stribeck curve) is predicted as a function of the wear rate.

\subsection{Geometry of worn contacts}

To predict the evolution of the Stribeck curve in time, it is necessary to know the evolution of contact geometry due to wear at different stages during operation of a system.

\subsubsection{Evolution of line and point contacts geometry in time}

Contact geometry plays an important role in formation of the separation between contacting surfaces in worn lubricated contacts. Components geometry evolves in time: at first a Hertzian contact takes place which changes due to wear as a function of the operational conditions. With the model presented an engineer is able to predict if friction during the life time is maintained. Evolution of the contact geometry due to wear is calculated based on a modified model [1] using observations from experimental wear tests (chapter 5):

- the pin geometry changes whilst the wear depth of the disc is negligible,

- all pin profiles after wear tests show a curvature $\left(\mathrm{R}_{\mathrm{w}}\right)$ which is larger than the original pin curvature $\left(\mathrm{R}_{\mathrm{p}}\right)$.

The wear is implemented in the model by using the Archard relation [2]:

$$
\mathrm{k}=\frac{\Delta \mathrm{V}}{\mathrm{F} \cdot \Delta \mathrm{s}}
$$


If the volume of material removed from the pin is given by $\Delta \mathrm{V}=\mathrm{A}_{\text {nom }} \cdot \Delta \mathrm{w}$, then the relation (7.1) transforms in:

$$
\Delta \mathrm{w}=\mathrm{k} \cdot \mathrm{p}_{\text {mean }} \cdot \Delta \mathrm{s}
$$

where: $\Delta \mathrm{w} \quad$ increase in wear depth $[\mathrm{m}]$

$\Delta \mathrm{s} \quad$ increase in sliding distance $[\mathrm{m}]$

$\Delta \mathrm{V} \quad$ increase in volume of the material removed $\left[\mathrm{mm}^{3}\right]$

$\mathrm{k} \quad$ wear rate $\left[\mathrm{mm}^{3} / \mathrm{N} \cdot \mathrm{m}\right]$

$\mathrm{p}_{\text {mean }} \quad$ increase in mean contact pressure $[\mathrm{Pa}]$

The wear model allows the calculation of the pin geometry parameters $\left(\mathrm{L}_{\mathrm{w}}\right.$ and $\left.w\right)$ using a value for the wear rate. A value can be taken from experiments, for instance chapter 5. The flow chart of the wear model (Figure 7.1) starts with the calculation of the Hertzian contact dimensions (see Appendix A). The elastic deformation normal to the contact in the case of point contact is calculated using the relation [3]:

$$
\mathrm{h}_{\mathrm{i}+1}^{\mathrm{e}}=\frac{\mathrm{F}_{\mathrm{N}}}{\mathrm{E}_{\mathrm{red}} \mathrm{L}_{\mathrm{w}_{\mathrm{i}+1}}}
$$

For a line contact the normal deformation is computed using the relation adopted from [1] for the assumed line contact area.

$$
\mathrm{h}_{\mathrm{i}+1}^{\mathrm{e}}=\frac{\mathrm{F}_{\mathrm{N}}}{\mathrm{E}_{\text {red }} \sqrt{\mathrm{L}_{\mathrm{w}_{\mathrm{i}+1} \mathrm{~B}}}}
$$

The mean contact pressure ( $\mathrm{p}_{\text {mean }}$ ) and the wear depth (w) are calculated for each increment of sliding distance (for example: $\Delta s=2 \pi \cdot r_{\text {track }}$ one rotation of the disc) till a certain sliding distance is reached.

$$
\left.\mathrm{p}_{\text {mean }}=\frac{\mathrm{F}_{\mathrm{N}}}{2 \mathrm{~L}_{\mathrm{w}} \mathrm{B}}(\text { line contact }), \mathrm{p}_{\text {mean }}=\frac{\mathrm{F}_{\mathrm{N}}}{\pi \mathrm{L}_{\mathrm{w}}^{2}} \text { (point contact }\right)
$$




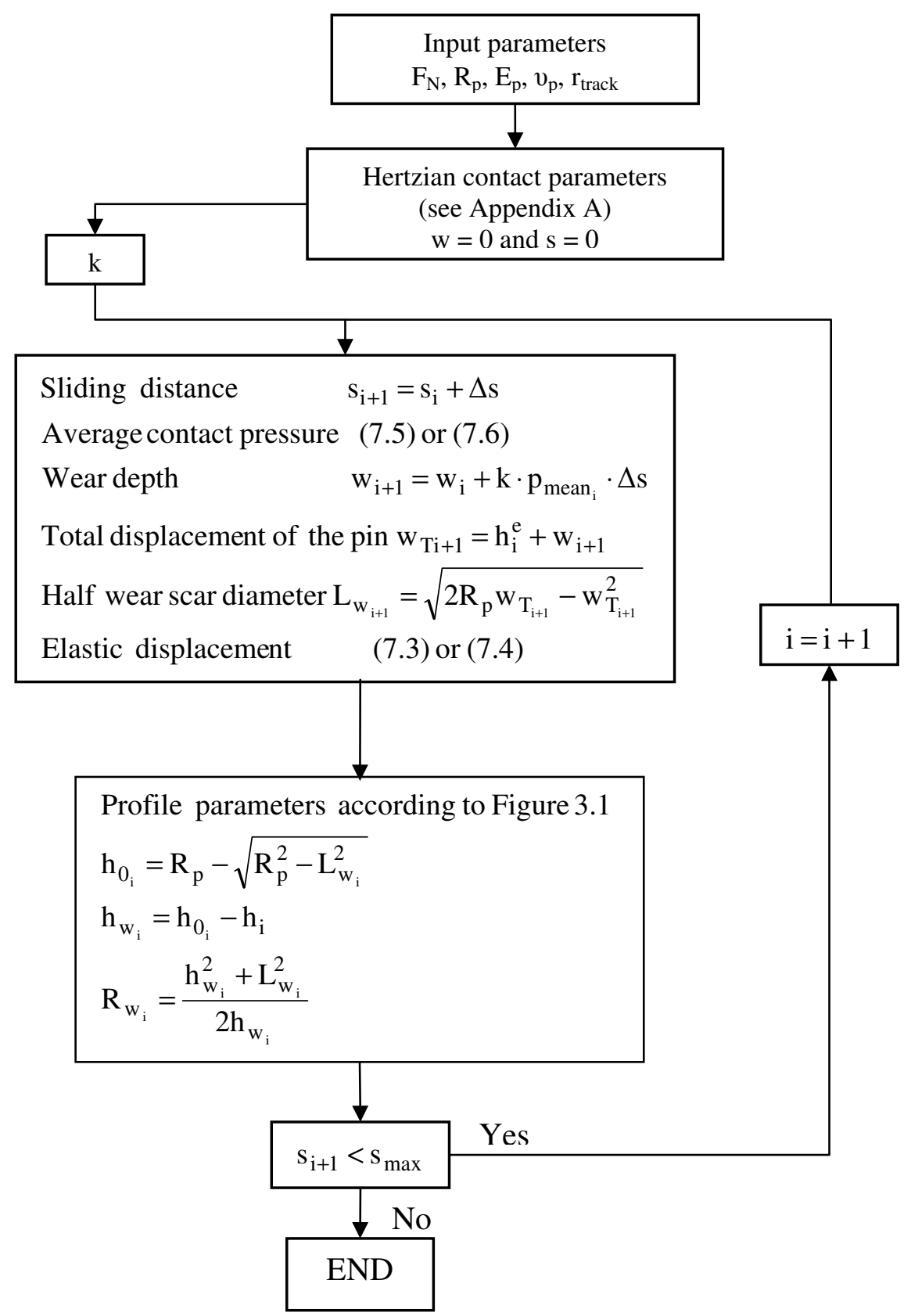

Figure 7.1 Flow chart of the wear model used to calculate the pin profile geometry in the case of a line or point contact. 
The results from the wear model are compared with the experimental results from wear test (see Table 5.4 and Table 5.5).

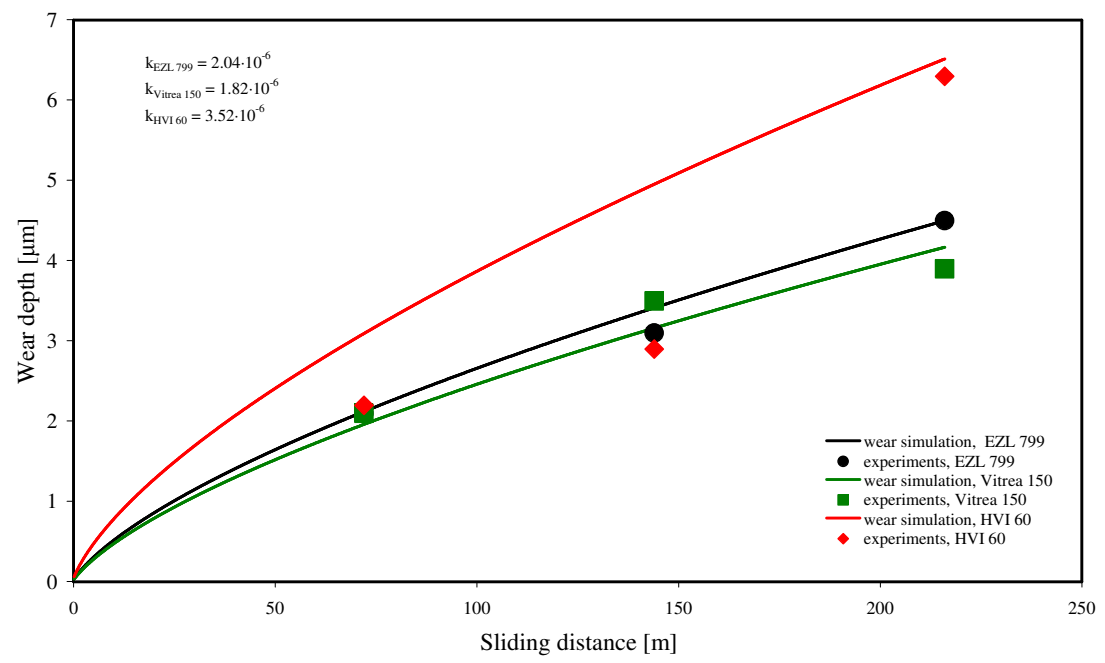

Figure 7.2 Comparison between wear model and experimental results from wear tests for different lubricants: Esso EZL 799, Shell Vitrea 150 and Shell HVI 60 in the case of a line contact.

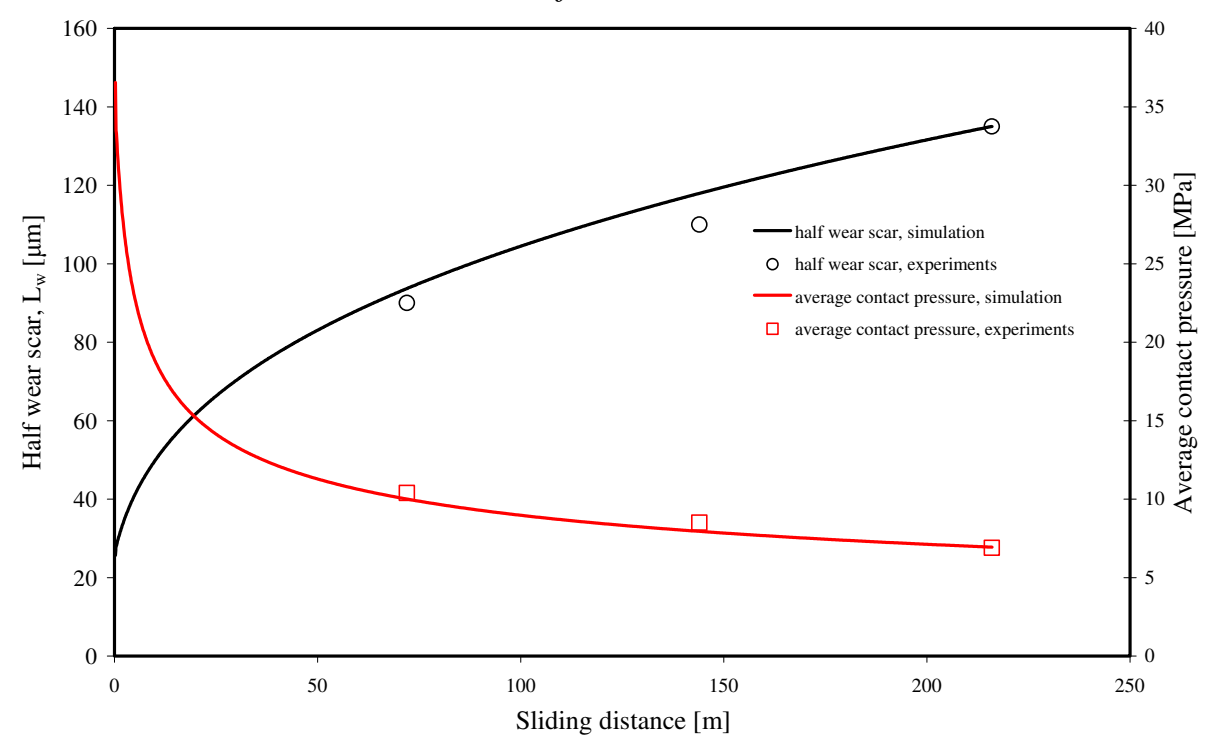

Figure 7.3 Comparison between simulation and experiments: evolution of wear scar and average contact pressure for the line contact situation using Esso EZL 799 as a lubricant. 


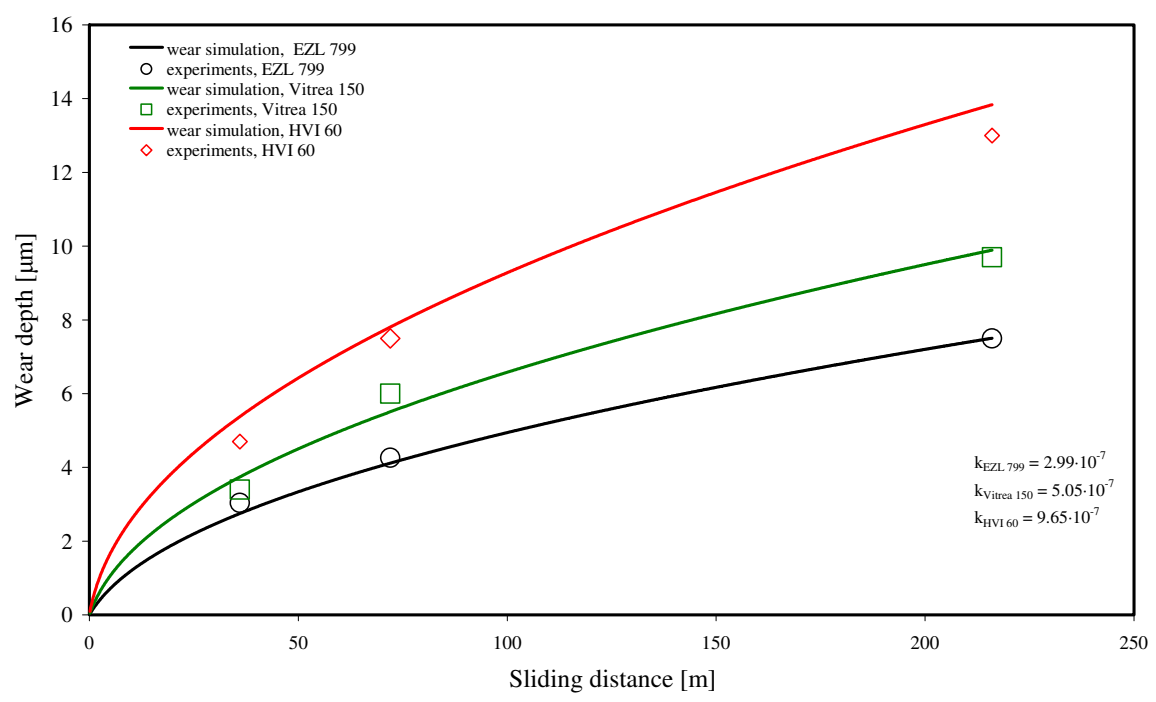

Figure 7.4 Comparison between wear model and experimental results from wear tests for different lubricants: Esso EZL 799, Shell Vitrea 150 and Shell HVI 60 in the case of a point contact.

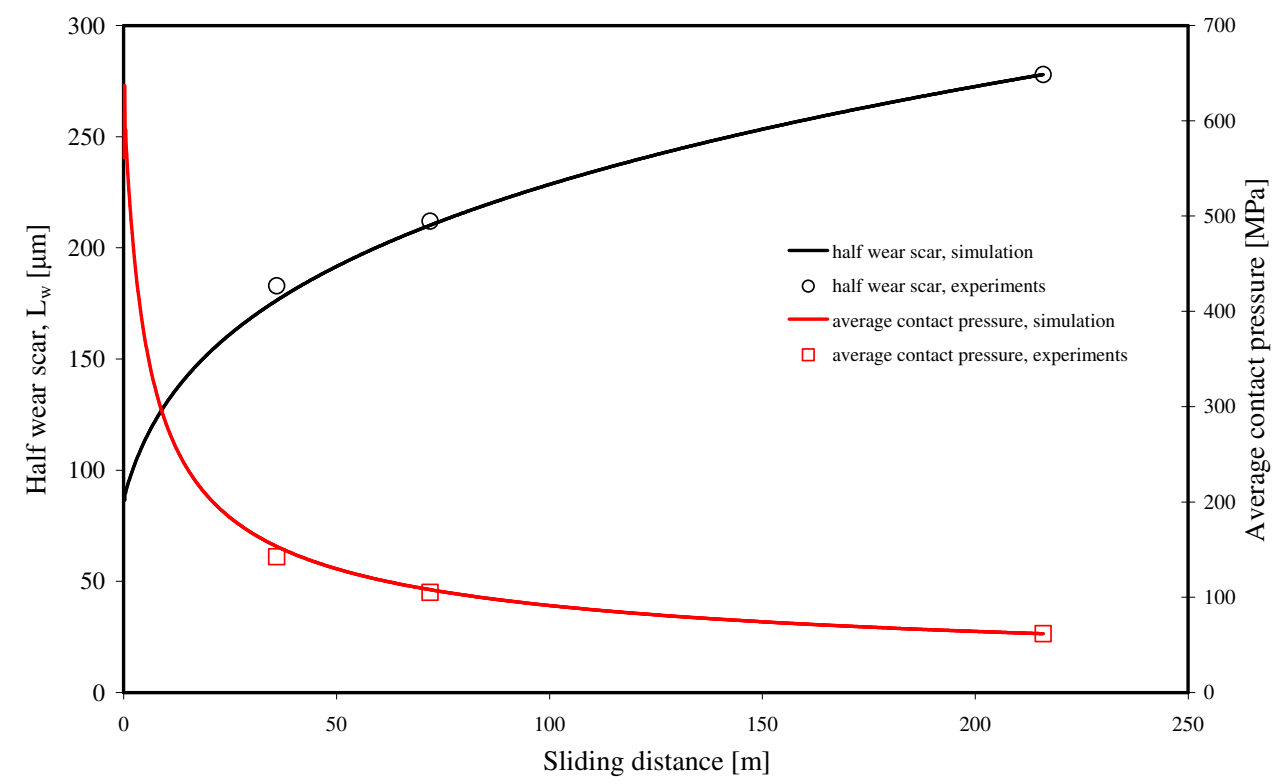

Figure 7.5 Comparison between simulation and experiments: evolution of wear scar and average contact pressure for a point contact using Esso EZL 799 as a lubricant. 
The figures show good agreement between simulation and wear experiments. This observation leads to the conclusion that the wear model can be used to define the contact geometry of the worn contacts at different stages during the wear process so that the evolution of the Stribeck curve in time can be simulated for line and point contacts.

\subsection{Evolution of the Stribeck curve in time for worn line contacts}

Based on the results presented in the previous section and on the mixed lubrication friction model, it is possible to simulate the predicted Stribeck curve for different stages during service of a system.

Figure 7.6 shows the predicted Stribeck curves after certain sliding distances. It can be noted that by increasing the sliding distance (from 0 to $2 \mathrm{~m}$ ), the Stribeck curves shifts to the left, which results in a change of the frictional behaviour of the system. This is particularly the case when operating at a velocity of $1 \mathrm{~m} / \mathrm{s}$, due to occurrence of the hydrodynamic effects as a result of changes in contact geometry (increase in width of the wear scar from $12.8 \mu \mathrm{m}$ to $67 \mu \mathrm{m}$ ). The same frictional behaviour is found by [4].

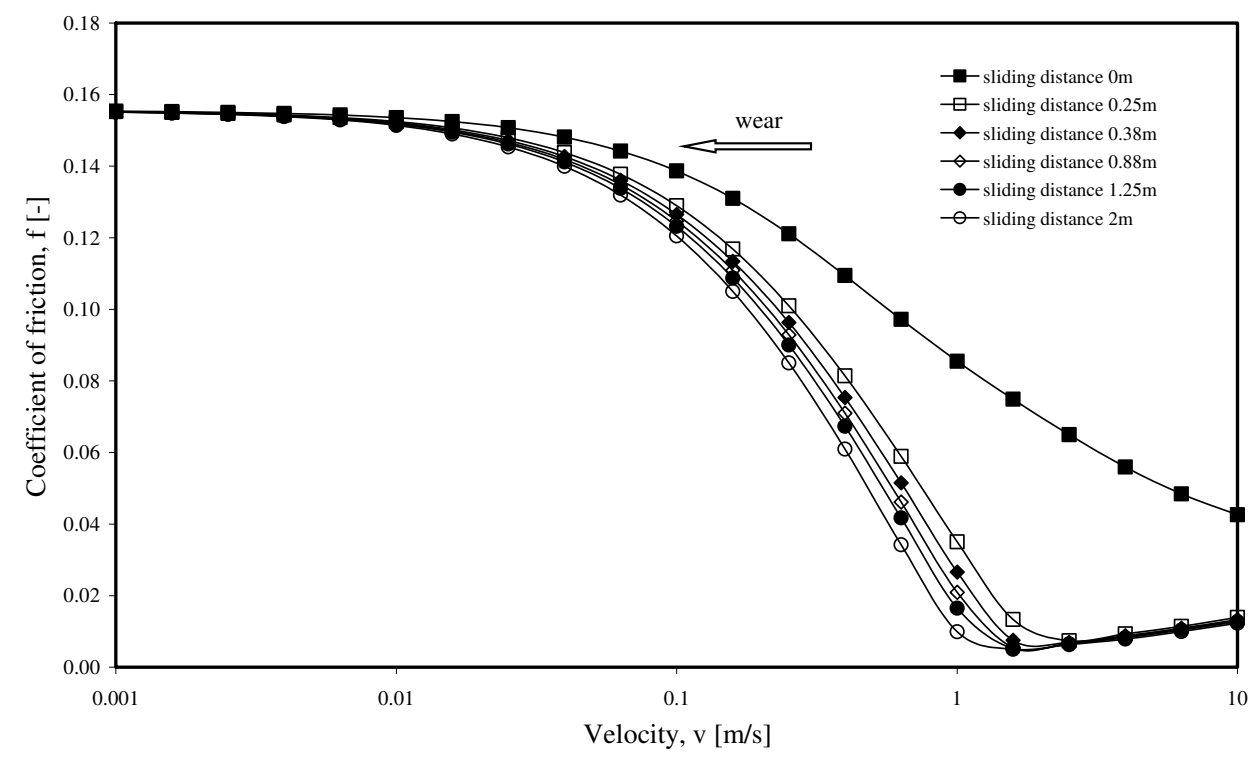

Figure 7.6 Evolution of the Stribeck curve in time for a line contact, using EZL 799 as lubricant. $F_{N}=15[\mathrm{~N}], \eta_{0}=0.02\left[\right.$ Pas], $R_{c y l}=2[\mathrm{~mm}], B=8[\mathrm{~mm}], k=$ $2 \cdot 10^{-6}\left[\mathrm{~mm}^{3} / \mathrm{N} \cdot \mathrm{m}\right]$. 


\subsection{Conclusions}

This chapter presents the evolution of the Stribeck curve in time using a wear model proposed to calculate the contact geometry at different stages throughout the operational time of a system. The results from the wear model simulation show good agreement with experimental results from wear tests performed on a pin-ondisc tribometer.

When the evolution of the contact geometry in time is know, the influence of macroscopic wear on friction in lubricated concentrated contact can be simulated using the mixed lubrication friction model proposed in chapter 4 .

\subsection{References}

[1] Hegadekatte, V., Huber, N. and Kraft, O., "Modeling and simulation of wear in a pin-on-disc tribometer", Tribology Letters, Vol. 24, No.1, 2006, pp. 51-60.

[2] Archard, J.F., "Contact and rubbing of flat surfaces", Journal of Applied Physics, Vol. 24, 1953, p. 981-988.

[3] Olivier, W.C. and Pharr G.M.A., "A new improved technique for determining hardness and elastic modulus using load and sensing indentation experiments", Journal of Materials. Research, Vol. 7, no. 6, 1992, pp. $1564-1582$.

[4] Schipper, D.J. "Transitions in the lubrication of concentrated contacts", $\mathrm{PhD}$ thesis, University of Twente, The Netherlands, 1988, pp. 5.15-5.23 


\section{Chapter 8 Conclusions and recommendations}

\subsection{Summary / Conclusions}

The main goal of this research was to investigate the influence of macroscopic wear on friction in lubricated concentrated contacts.

The first step consisted in carrying out experimental tests (wear and friction tests) in order to observe the major changes in the contact due to wear. By changing the operational test parameters (running time, contact geometry, lubricant) following an experimental procedure, the evolution of the contact geometry due to wear was studied. All tests show that by increasing the running time the contact area increases (wear scar increasing) and by that a reduction in the contact pressure occurs. The rate of change in contact geometry depends on the type of lubricant used. The friction tests show that by increasing wear the friction in lubricated contacts decreases as presented by the friction tests in chapter 5 .

Measurements of the surface topography after the wear tests (different running time/sliding distance) indicate an insignificant difference between surface parameters (see value of $\sigma$ from table 5.4 and 5.5) from which it may be concluded that: the decrease in friction is due to change in contact geometry.

Based on this observation the influence of wear on minimum film thickness was modelled using the hydrodynamic lubrication theory (solving the Reynolds equation and using the inlet shape geometry of the worn contact).

In order to be able to predict friction in worn lubricated concentrated contacts a deterministic mixed lubrication friction model is proposed. The main input parameters are: load, velocity, lubricant properties, contact geometry and topography of the worn surface. This model is based on the assumption that the total load is shared between the interacting asperities and hydrodynamic action. Using the surface topography of the worn surfaces after friction test in a contact model, the load carried by the asperities is found by summation of each individual microcontact. The hydrodynamic action is given by the solution of the minimum film thickness for each concentrated contact from chapter 3 . 
The experiments and simulations show that by increasing wear in lubricated contacts a decrease in friction occurs and leads to a shift of the Stribeck curve to the left which means a change in operational regime (from BL to ML). This change can be attributed to an increase in hydrodynamic effects which occur in the contact due to a decrease in the contact pressure and with that an increase in separation.

Finally, Stribeck curves in time were predicted using the evolution of contact geometry at different stages through the operational time of a system.

\subsection{Discussion / Recommendations}

In this thesis the calculation of the separation between contacting surfaces was made based on observation from pin-on-disc wear tests in which only the pin geometry is modifying in time which is the situation in applications where the wear of a system is governed by the wear of one of the components in the contact. As future work it is recommended to study the effect of wear on friction in systems where both components change in geometry. The method described in this thesis can be adapted for this purpose.

In chapter 7 the change in friction (Stribeck curve) is given in time using a certain value for $\mathrm{k}$. Friction in systems depends on the operational conditions, also $\mathrm{k}$ is.

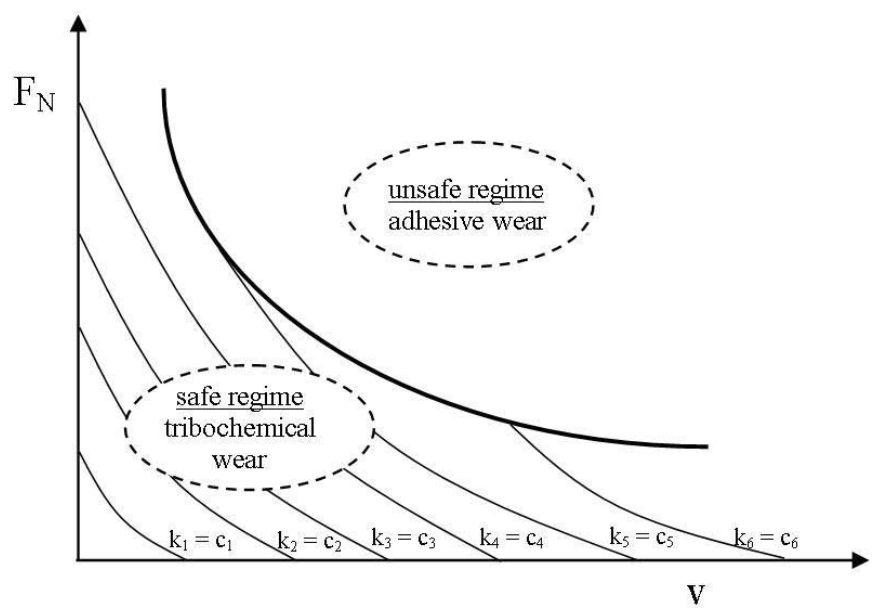

Figure 8.1 IRG-OECD transition diagram.

Tribosystems are designed to operate in the safe region of the IRG-OECD transition diagram. The wear mechanism in the safe region is of tribochemical nature. In this region wear is calculated by Bosman $\left[{ }^{1}\right]$ and is able to draw iso-wear 
rate lines as schematically drawn, in Figure 8.1, i.e. $k=f\left(F_{N}, v\right)$. Combining this model with the model presented in this thesis will enable an engineer to predict the frictional behaviour in time of systems considered.

\subsection{References}

[1] Bosman, R. "Wear in boundary lubricated contacts", 2010, private communication. 
Appendices 


\section{Appendix A. Hertzian contacts}

\section{A.1 Line contact}

A line contact is achieved at the contact between two cylinders loaded with a normal load see Figure A.1.

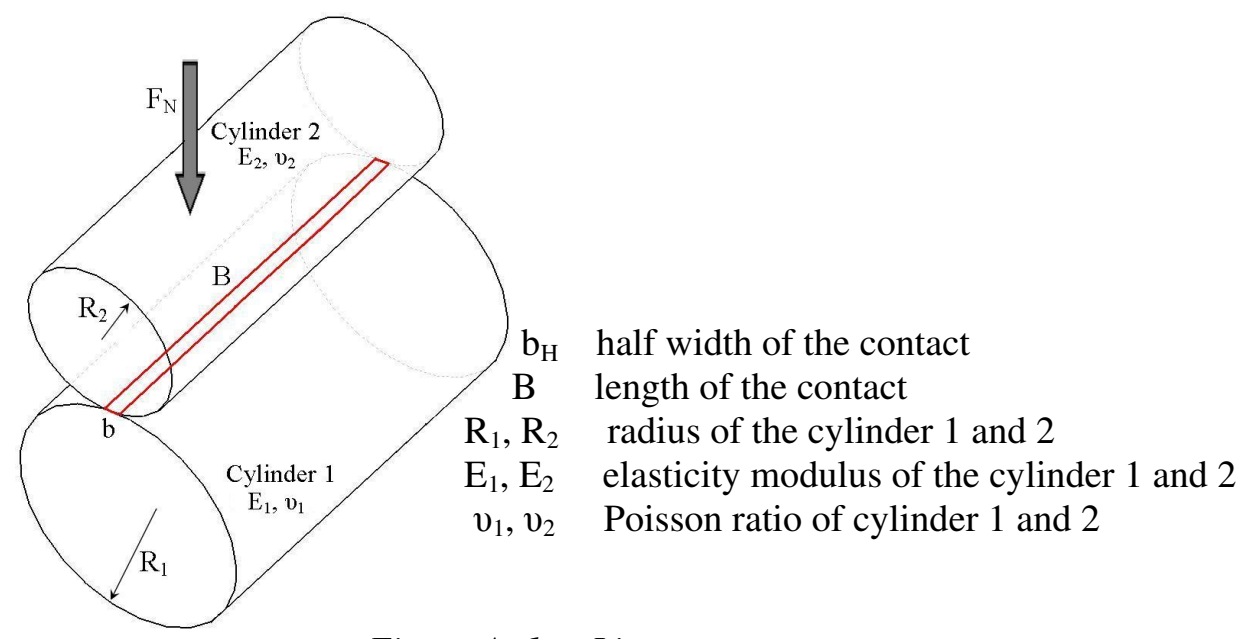

Figure A. 1 Line contact geometry.

The main parameter characterizing the line contact is given by the following relation [1]:

$$
\mathrm{b}_{\mathrm{H}}=2 \sqrt{\frac{2 \mathrm{~F}_{\mathrm{N}} \mathrm{R}_{\mathrm{red}}}{\pi \mathrm{BE}}}
$$

with: $\frac{2}{\mathrm{E}_{\text {red }}}=\frac{1-v_{1}^{2}}{\mathrm{E}_{1}}+\frac{1-v_{2}^{2}}{\mathrm{E}_{2}}$ and $\frac{1}{\mathrm{R}_{\mathrm{red}}}=\frac{1}{\mathrm{R}_{1}}+\frac{1}{\mathrm{R}_{2}}$

The mean and maximum contact pressure are calculated as:

$$
\mathrm{p}_{\text {mean }}=\frac{\mathrm{F}_{\mathrm{N}}}{2 \mathrm{~b}_{\mathrm{H}} \mathrm{B}}, \mathrm{p}_{\max }=\frac{4}{\pi} \mathrm{p}_{\text {mean }}
$$




\section{A.2 Elliptical contact}

The contact area between two ellipsoids subjected to a normal load $\mathrm{F}_{\mathrm{N}}$ is an ellipse whose dimensions (semi-axis) can be calculated based on the next equations:

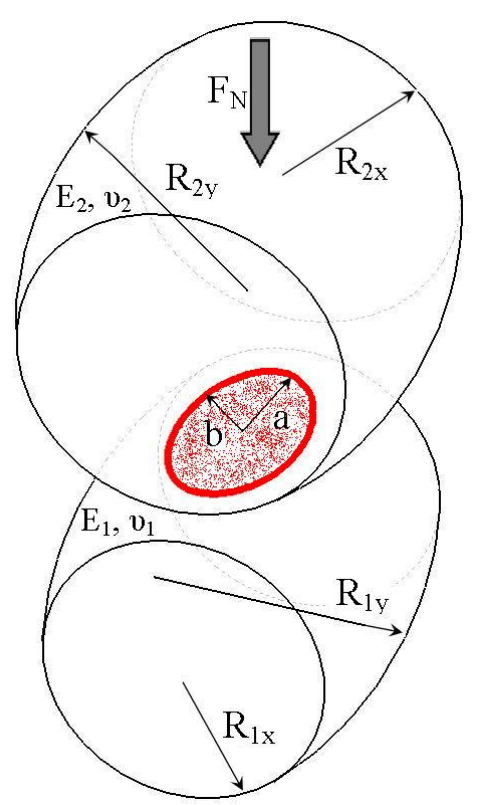

$$
\frac{1}{\mathrm{R}_{\text {red }}}=\frac{1}{\mathrm{R}_{1 \mathrm{x}}}+\frac{1}{\mathrm{R}_{2 \mathrm{x}}}+\frac{1}{\mathrm{R}_{2 \mathrm{x}}}+\frac{1}{\mathrm{R}_{2 \mathrm{y}}}
$$

Major semi-axis

$$
a=\alpha_{E}\left(\frac{3 F_{N} R_{\text {red }}}{E_{\text {red }}}\right)^{\frac{1}{3}}, \alpha_{E}=\kappa^{\frac{1}{3}}\left[\frac{2}{\pi} E(m)\right]^{\frac{1}{3}}
$$

Minor semi-axis

$$
\mathrm{b}=\beta\left(\frac{3 \mathrm{~F}_{\mathrm{N}} \mathrm{R}_{\mathrm{red}}}{\mathrm{E}_{\text {red }}}\right)^{\frac{1}{3}}, \beta=\kappa^{-\frac{2}{3}}\left[\frac{2}{\pi} \mathrm{E}(\mathrm{m})\right]^{\frac{1}{3}}
$$

The coefficients $\alpha$ and $\beta$ are calculated by using the next relations having as condition $0<\lambda \leq 1$, where $\lambda=\mathrm{R}_{\mathrm{x}} / \mathrm{R}_{\mathrm{y}}$.

$$
\begin{gathered}
\kappa=\left[1+\sqrt{\frac{\ln (16 / \lambda)}{2 \lambda}}-\sqrt{\ln (4)}+0.16 \ln (\lambda)\right]^{-1} \\
m=1-\kappa^{2} \\
E(m)=\frac{\pi}{2}(1-m)\left\{1+\frac{2 m}{\pi(1-m)}-\frac{1}{8} \ln (1-m)\right\}
\end{gathered}
$$

The mean and the maximum contact pressure are given by:

$$
\mathrm{p}_{\text {mean }}=\frac{\mathrm{F}_{\mathrm{N}}}{\pi \mathrm{ab}}, \quad \mathrm{p}_{\text {max }}=\frac{3}{2} \mathrm{p}_{\text {mean }}
$$




\section{A.3 Point contact}

The point contact is a special case of the elliptical contact $\left(R_{1 x}=R_{1 y}=R_{1}, R_{2 x}=\right.$ $R_{2 y}=R_{2}$ which results in $\alpha=\beta=1$ ). The radius of the contact can be calculated according to [2].

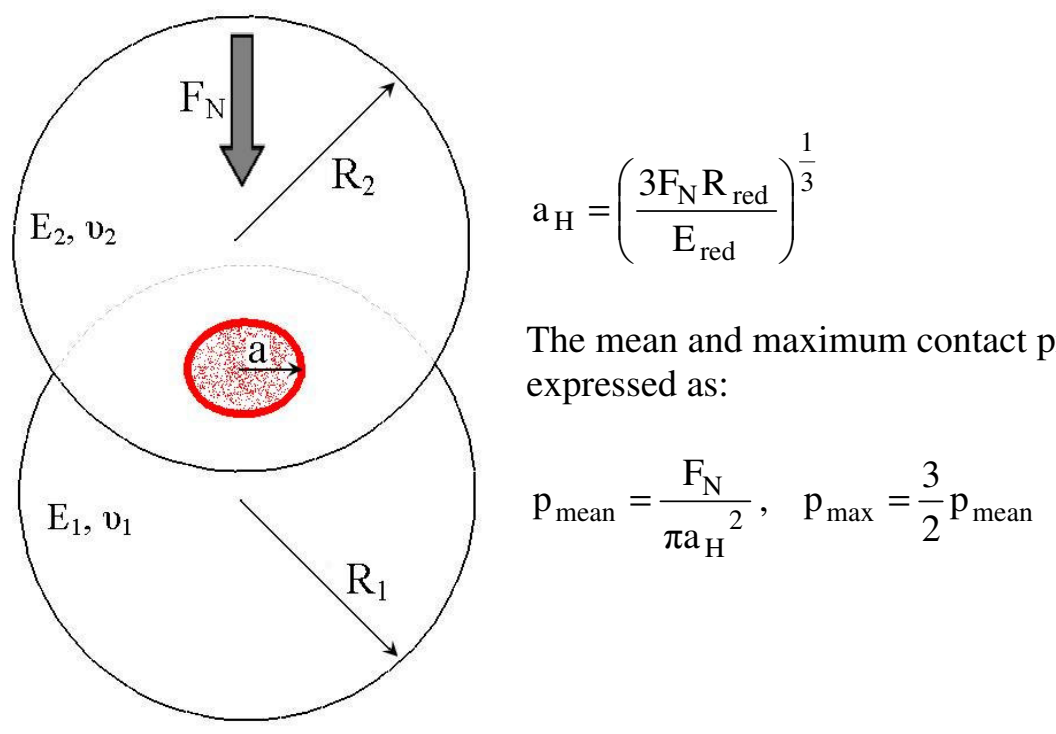

Figure A. 3 Point contact geometry.

\section{A.4 References}

[1] Johnson, K.L., "Contact Mechanics", Cambridge University Press, 1985.

[2] Hertz, H. "Über die Berührung fester elastischer Körper", Journal für die reine und angewandte Mathematik, Vol. 92, 1881, pp. 156-171. 


\section{Appendix B. Definition of roughness parameters}

In Chapter 4 the deterministic mixed lubrication friction model for predicting the Stribeck curve for worn lubricated concentrated contacts was discussed. This model uses as input parameter the surface topography of the wear scar from the pins which are measured by an interference microscope (see Figure B.1-a).

In order to find the asperities of a worn surface a 9-point summit definition is used [1]. According to this a point is defined as a summit only if its 8 surrounding points are lower (see Figure B.1-b).

a)

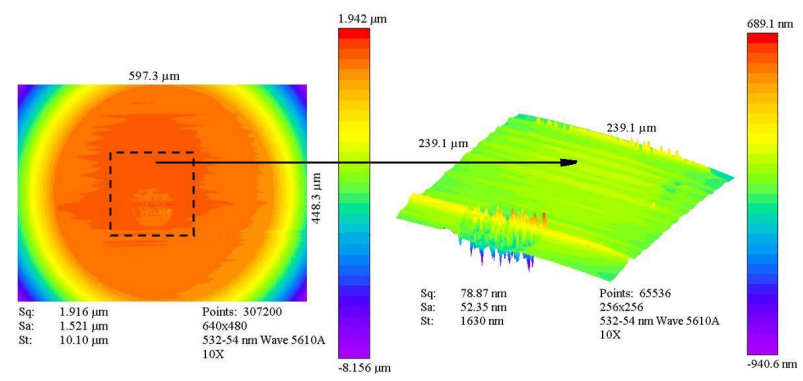

b)

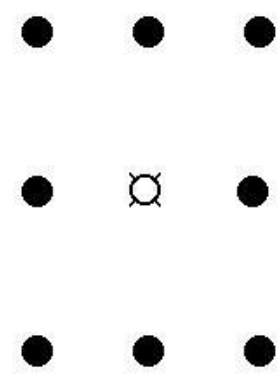

Figure B. $1 \quad$ a) Surface topography of a wear scar after a friction test and $b$ ) summit definition.

Using the theory from [1] the asperities are considered to be as ellipsoids. The radius of the asperity $\beta$ is related to the local curvature of the surface and can be calculated according to [2] by using the 3-point definition:

$$
\begin{aligned}
& \beta_{i x}^{-1}=-\frac{z_{x-\Delta x, y}-2 z_{x, y}+z_{x+\Delta x, y}}{\Delta x^{2}} \\
& \beta_{i y}^{-1}=-\frac{z_{x, y-\Delta y}-2 z_{x, y}+z_{x, y+\Delta y}}{\Delta y^{2}}
\end{aligned}
$$

where: $\beta_{\mathrm{ix}}, \beta_{\mathrm{iy}} \quad$ the radii in $\mathrm{x}$ respectively y direction

$\mathrm{z}_{\mathrm{x}}, \mathrm{z}_{\mathrm{y}} \quad$ the local surface height at the location ( $\left.\mathrm{x}, \mathrm{y}\right)$

$\Delta_{\mathrm{x}}, \Delta_{\mathrm{y}} \quad$ the pixel size in $\mathrm{x}$ respectively y direction 
The radius of the asperity can be found by combining the radii in the two directions by applying the next relation:

$$
\beta_{\mathrm{i}}=\frac{\beta_{\mathrm{ix}}+\beta_{\mathrm{iy}}}{2}
$$

Some examples of pin surface measurements by interference microscopy after "wear" tests are presented in Figure B.2:

a)

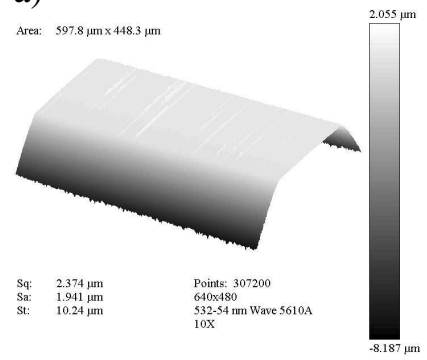

b)

Area: 5970 ,

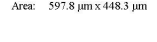

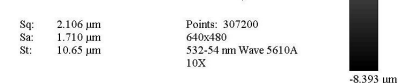

c)

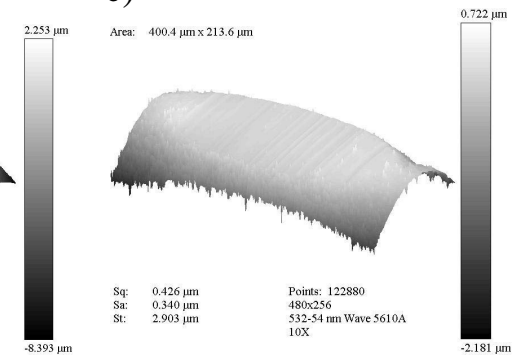

Figure B. 2 Pin surface measurements after "wear" test - a) line contact, b) point contact and c) elliptical contact.

\section{B.1 References}

[1] Rooij, M.B., "Tribological aspects of unlubricated deepdrawing process", $\mathrm{PhD}$ thesis, University of Twente, The Netherlands, 1998.

[2] Greenwood, J.A., "A unified theory of surface roughness", Proceedings of the Royal Society of London, Vol. 393, 1984, pp. 133-157. 


\section{Appendix C. Film thickness in concentrated contacts without wear}

In this appendix a literature overview of the minimum film thickness equations for different concentrated contacts (when wear does not occur in the contact) is presented.

\section{C.1 Minimum film thickness for the line contact situation}

Prediction of the minimum film thickness can be found, for instance, in $[1,2]$. The general solution is:

$$
\mathrm{H}_{\min }=\mathrm{k}_{1} \cdot \mathrm{G}^{\mathrm{k}_{2}} \cdot \mathrm{U}^{\mathrm{k}_{3}} \cdot \mathrm{W}^{\mathrm{k}_{4}}
$$

with values for $\mathrm{k}_{\mathrm{i}}$ given in table $\mathrm{C} 1$ in which the dimensionless numbers are defined as:

$$
H_{\text {min }}=\frac{h_{\text {min }}}{R_{x}}, \quad G=\alpha E_{\text {red }}, \quad U=\frac{\eta_{0} v}{E_{r e d} R_{x}}, \quad W=\frac{F_{N}}{B E_{r e d} R_{x}}
$$

Table C $1 \quad$ Values of the constants from equation (C.1).

\begin{tabular}{|c|c|c|c|c|}
\hline Reference & $\mathrm{k}_{1}$ & $\mathrm{k}_{2}$ & $\mathrm{k}_{3}$ & $\mathrm{k}_{4}$ \\
\hline$[1]$ & 1.6 & 0.6 & 0.7 & -0.13 \\
\hline$[2]$ & 3.07 & 0.57 & 0.71 & -0.11 \\
\hline
\end{tabular}

Moes [3] presented a formula for the minimum film thickness for line contacts which is based on the four lubrication regimes: RI, RP, EI and EP.

$$
\begin{gathered}
\mathrm{H}=\left\{\left(\mathrm{H}_{\mathrm{RI}}^{7 / 3}+\mathrm{H}_{\mathrm{EI}}^{7 / 3}\right)^{3 \mathrm{~s} / 7}+\left(\mathrm{H}_{\mathrm{RP}}^{-7 / 2}+\mathrm{H}_{\mathrm{EP}}^{-7 / 2}\right)^{-2 \mathrm{~s} / 7}\right\}^{1 / \mathrm{s}} \\
\mathrm{s}=\frac{1}{5}\left\{7+8 \mathrm{e}^{-2 \frac{\mathrm{H}_{\mathrm{EI}}}{\mathrm{H}_{\mathrm{RI}}}}\right\} \\
\mathrm{H}_{\mathrm{RI}}=3 \cdot \mathrm{M}^{-1}
\end{gathered}
$$




$$
\begin{aligned}
& \mathrm{H}_{\mathrm{RP}}=1.2866 \cdot \mathrm{L}^{2 / 3} \\
& \mathrm{H}_{\mathrm{EI}}=2.621 \cdot \mathrm{M}^{-1 / 5} \\
& \mathrm{H}_{\mathrm{EP}}=1.311 \cdot \mathrm{M}^{-1 / 8} \cdot \mathrm{L}^{3 / 4}
\end{aligned}
$$

The dimensionless groups used in the given equations are:

$$
\begin{gathered}
\mathrm{H}=\frac{\mathrm{h}_{\text {min }}}{\mathrm{R}_{\text {red }}}\left(\frac{\mathrm{E}_{\text {red }} \cdot \mathrm{R}_{\text {red }}}{\eta_{0} \cdot \mathrm{v}}\right)^{1 / 2} \quad \mathrm{M}=\frac{\mathrm{F}_{\mathrm{N}}}{\mathrm{B} \cdot \mathrm{E}_{\mathrm{red}} \cdot \mathrm{R}_{\text {red }}}\left(\frac{\mathrm{E}_{\text {red }} \cdot \mathrm{R}_{\text {red }}}{\eta_{0} \cdot \mathrm{v}}\right)^{1 / 2} \\
\mathrm{~L}=\alpha \cdot \mathrm{E}_{\text {red }}\left(\frac{\eta_{0} \cdot \mathrm{v}}{\mathrm{E}_{\text {red }} \cdot \mathrm{R}_{\text {red }}}\right)^{1 / 4}
\end{gathered}
$$

\section{C.2 Minimum film thickness for the elliptical contact situation}

The general solution of the minimum film thickness in elliptical contacts is given in [4] by:

$$
\begin{gathered}
\mathrm{H}=\left\{\left(\mathrm{H}_{\mathrm{RI}}^{3 / 2}+\left(\mathrm{H}_{\mathrm{EI}}^{-4}+\mathrm{H}_{00}^{-4}\right)^{-3 / 8}\right)^{2 \mathrm{~s} / 3}+\left(\mathrm{H}_{\mathrm{RP}}^{-8}+\mathrm{H}_{\mathrm{EP}}^{-8}\right)^{-\mathrm{s} / 8}\right\}^{\frac{1}{\mathrm{~s}}} \\
\mathrm{~s}=\frac{3}{2}\left\{1+\mathrm{e}^{-1.2 \frac{\mathrm{H}_{\mathrm{EI}}}{\mathrm{H}_{\mathrm{RI}}}}\right\} \\
\mathrm{H}_{00}=1.8 \mathrm{D}^{-1} \\
\lambda=\frac{\mathrm{R}_{\mathrm{x}}}{\mathrm{R}_{\mathrm{y}}} \\
\mathrm{H}=\frac{\mathrm{h}_{\text {min }}}{\mathrm{R}_{\mathrm{x}}}\left(\frac{\mathrm{E}_{\mathrm{red}} \cdot \mathrm{R}_{\mathrm{x}}}{\eta_{0} \cdot \mathrm{v}}\right)^{1 / 2}
\end{gathered}
$$




$$
\begin{aligned}
& \mathrm{M}=\frac{\mathrm{F}_{\mathrm{N}}}{\mathrm{E}_{\text {red }} \cdot \mathrm{R}_{\mathrm{x}}^{2}}\left(\frac{\eta_{0} \mathrm{v}}{\mathrm{E}_{\text {red }} \cdot \mathrm{R}_{\text {red }}}\right)^{3 / 4} \\
& \mathrm{~L}=\alpha \cdot \mathrm{E}_{\text {red }}\left(\frac{\eta_{0} \cdot \mathrm{v}}{\mathrm{E}_{\text {red }} \cdot \mathrm{R}_{\mathrm{x}}}\right)^{1 / 4}
\end{aligned}
$$

The dimensionless film thickness equations for all regimes are expressed as:

$$
\begin{gathered}
\mathrm{H}_{\mathrm{RI}}=145 \cdot\left(1+0.796 \cdot \lambda^{14 / 15}\right)^{-15 / 7} \lambda^{-1} \cdot \mathrm{M}^{-2} \\
\mathrm{H}_{\mathrm{RP}}=1.29 \cdot(1+0.691 \cdot \lambda)^{-2 / 3} \cdot \mathrm{L}^{2 / 3} \\
\mathrm{H}_{\mathrm{EI}}=3.18 \cdot\left(1+0.006 \ln (\lambda)+0.63 \cdot \lambda^{4 / 7}\right)^{-14 / 25} \cdot \lambda^{-1 / 15} \cdot \mathrm{M}^{-2 / 15} \\
\mathrm{H}_{\mathrm{EP}}=1.48 \cdot\left(1+0.006 \ln (\lambda)+0.63 \cdot \lambda^{4 / 7}\right)^{-7 / 20} \cdot \lambda^{-1 / 24} \cdot \mathrm{N}^{-1 / 12} \cdot \mathrm{L}^{3 / 4}
\end{gathered}
$$

Several researchers presented formulas for the elliptical and point contact situation which can be represented in general by:

$$
\mathrm{H}_{\text {min }}=\mathrm{k}_{1} \cdot \mathrm{G}^{\mathrm{k}_{2}} \cdot \mathrm{U}^{\mathrm{k}_{3}} \cdot \mathrm{W}^{\mathrm{k}_{4}} \cdot \mathrm{f}(\xi)
$$

where: $f(\xi)$ is a function which depends on the contact ellipticity ratio ( $\xi=1$ for point contacts and $\xi=\mathrm{b} / \mathrm{a}$ for elliptical contacts)

Table C 2 Values of the constants from equation (C.20).

\begin{tabular}{|c|c|c|c|c|c|c|}
\hline Contact & Reference & $\mathrm{k}_{1}$ & $\mathrm{k}_{2}$ & $\mathrm{k}_{3}$ & $\mathrm{k}_{4}$ & $\mathrm{f}(\xi)$ \\
\hline Point & {$[5]$} & 1.55 & 0.725 & 0.725 & -0.058 & 1 \\
\hline Elliptic & {$[6]$} & 3.63 & 0.49 & 0.68 & -0.073 & $1-\mathrm{e}^{-0.68 \xi}$ \\
\hline & {$[7]$} & 3.68 & 0.49 & 0.68 & -0.073 & $1-\mathrm{e}^{-0.67 \xi}$ \\
\hline
\end{tabular}

Dimensionless parameters $\mathrm{H}_{\text {min }}, \mathrm{G}, \mathrm{U}$ are defined according to equation (C.2) and the load parameter is given by $\mathrm{W}=\frac{\mathrm{F}_{\mathrm{N}}}{\mathrm{E}_{\mathrm{red}} \cdot \mathrm{R}_{\mathrm{x}}^{2}}$. 


\section{C.3 References}

[1] Dowson, D. and Higginson, G.R., "Elasto-hydrodynamic lubrication", Pergamont Press, Oxford, 1966.

[2] Hamrock, B.J. and Jacobsen, B.O., "Elasto-hydrodynamic of line contacts", ASLE Trans., Vol. 27, 1984, pp.275-287.

[3] Moes, H., "Lubrication and beyond", lecture notes, Print Partners Ipskamp B.V., Enschede, The Netherlands, 2000, pp. 173-180, available on: http://www.tr.ctw.utwente.nl/Organisation/Links.

[4 ] Nijenbanning, G., Venner, C.H. and Moes, H., "Film thickness in elastohydrodynamically lubricated elliptic contacts", Wear, Vol. 176, 1994, pp.217-229.

[5] Chang, H.S., "A numerical solution of the elastohydrodynamic film thickness in elliptical contact", ASME JOLT, Vol. 92, 1970, pp155-162.

[6] Hamrock, B.J. amd Dowson D., "Isothermal EHL of point contact, Part III: fully flooded results", ASME JOLT, Vol. 99, 1977, pp. 264-276.

[7] Chittenden, R.J., Dowson, D., Dunn, J.F. and Taylor, C.M., "A theoretical analysis of the isothermal elastohydrodynamic lubrication of concentrated contacts, I Direction of lubricant entrainment with the major axis of the Hertzian contact ellipse”, Proc. Roy. Soc. of London, Vol. A 397, 1985, p. 245 . 


\section{Appendix D. Input parameters}

\section{Line contact}

Load

Radius of the cylinder

Length of the cylinder

Velocity (wear test)

$$
\begin{aligned}
\mathrm{F}_{\mathrm{N}} & =15 \\
\mathrm{R}_{\mathrm{cyl}} & =2 \\
\mathrm{~B} & =8 \\
\mathrm{v} & =0.005
\end{aligned}
$$

$[\mathrm{N}]$

$[\mathrm{mm}]$

$[\mathrm{mm}]$

\begin{tabular}{|c|c|c|c|}
\hline Lubricant & Time $[\mathrm{h}]$ & Lubricant properties & Contact width, 2Lw [ $\mu \mathrm{m}]$ \\
\hline \multirow[t]{4}{*}{ Esso EZL 799} & 0 & \multirow{4}{*}{$\begin{array}{c}\eta_{0}=0.074[\mathrm{~Pa} \cdot \mathrm{s}] \\
\alpha=2 \cdot 10^{-8}\left[\mathrm{~Pa}^{-1}\right]\end{array}$} & 12.8 \\
\hline & 4 & & 180 \\
\hline & 8 & & 220 \\
\hline & 12 & & 270 \\
\hline \multirow[t]{4}{*}{ Shell Vitrea 150} & 0 & \multirow{4}{*}{$\begin{array}{c}\eta_{0}=0.404[\mathrm{~Pa} \cdot \mathrm{s}] \\
\alpha=2 \cdot 10^{-8}\left[\mathrm{~Pa}^{-1}\right]\end{array}$} & 12.8 \\
\hline & 4 & & 184 \\
\hline & 8 & & 240 \\
\hline & 12 & & 260 \\
\hline \multirow[t]{4}{*}{ Shell HVI 60} & 0 & \multirow{4}{*}{$\begin{array}{c}\eta_{0}=0.381[\mathrm{~Pa} \cdot \mathrm{s}] \\
\alpha=2.17 \cdot 10^{-8}\left[\mathrm{~Pa}^{-1}\right]\end{array}$} & 12.8 \\
\hline & 4 & & 204 \\
\hline & 8 & & 224 \\
\hline & 12 & & 324 \\
\hline
\end{tabular}

$[\mathrm{m} / \mathrm{s}]$

Table D. 1 Input parameters for minimum film thickness calculations in worn lubricated line contacts

\section{Elliptic contact}

Load

Radius of the spherical roller

Velocity (wear test)

$$
\begin{aligned}
\mathrm{F}_{\mathrm{N}} & =10 & & {[\mathrm{~N}] } \\
\mathrm{R}_{\mathrm{x}} & =4, \mathrm{R}_{\mathrm{y}}=26.67 & & {[\mathrm{~mm}] } \\
\mathrm{v} & =0.005 & & {[\mathrm{~m} / \mathrm{s}] }
\end{aligned}
$$

Table D. 2 Input parameters for minimum film thickness calculations in worn lubricated elliptic contact.

\begin{tabular}{|c|c|c|c|}
\hline Lubricant & Time $[\mathrm{h}]$ & Lubricant properties & Contact geometry $[\mu \mathrm{m}]$ \\
\hline Esso EZL 799 & 0 & \multirow{2}{*}{$\eta_{0}=0.074[\mathrm{~Pa} \cdot \mathrm{s}]$} & $2 \mathrm{a}=170,2 \mathrm{~b}=139$ \\
\cline { 1 - 1 } & 8 & \multirow{2}{*}{$\alpha=2 \cdot 10^{-8}\left[\mathrm{~Pa}^{-1}\right]$} & $2 \mathrm{a}=170,2 \mathrm{~b}=375$ \\
\cline { 1 - 1 } & 16 & & $2 \mathrm{a}=270,2 \mathrm{~b}=650$ \\
\hline & 40 & & $2 \mathrm{a}=340,2 \mathrm{~b}=840$ \\
\hline
\end{tabular}


Point contact

Load

$\mathrm{F}_{\mathrm{N}}=15$

$[\mathrm{N}]$

Radius of the sphere

$\mathrm{R}=5$

$[\mathrm{mm}]$

Velocity (wear test)

$\mathrm{v}=0.005$

$[\mathrm{m} / \mathrm{s}]$

Table D. 3 Input parameters for minimum film thickness calculations in worn

lubricated point contact.

\begin{tabular}{|c|c|c|c|}
\hline Lubricant & Time $[\mathrm{h}]$ & Lubricant properties & $\begin{array}{c}\text { Contact geometry, } \mathrm{d}_{\text {scar }} \\
{[\mu \mathrm{m}]}\end{array}$ \\
\hline ESSO EZL 799 & 0 & \multirow{4}{*}{$\begin{array}{c}\eta_{0}=0.074[\mathrm{~Pa} \cdot \mathrm{s}] \\
\alpha=2 \cdot 10^{-8}\left[\mathrm{~Pa}^{-1}\right]\end{array}$} & 157 \\
\hline & 4 & & 366 \\
\hline & 8 & & 424 \\
\hline & 12 & & 556 \\
\hline Shell Vitrea 150 & 0 & \multirow{4}{*}{$\begin{array}{l}\eta_{0}=0.404[\mathrm{~Pa} \cdot \mathrm{s}] \\
\alpha=2 \cdot 10^{-8}\left[\mathrm{~Pa}^{-1}\right]\end{array}$} & 157 \\
\hline & 4 & & 346 \\
\hline & 8 & & 572 \\
\hline & 12 & & 635 \\
\hline \multirow[t]{4}{*}{ Shell HVI 60} & 0 & \multirow{4}{*}{$\begin{array}{c}\eta_{0}=0.381[\mathrm{~Pa} \cdot \mathrm{s}] \\
\alpha=2.17 \cdot 10^{-8}\left[\mathrm{~Pa}^{-1}\right]\end{array}$} & 157 \\
\hline & 4 & & 448 \\
\hline & 8 & & 568 \\
\hline & 12 & & 748 \\
\hline
\end{tabular}

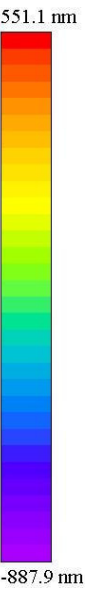

Figure D. $1 \quad$ Surface topography used as input in simulations for Figure 4.4. 
Table D. 4 Input parameters for the simulation of Figure 4.4.

\begin{tabular}{|l|c|c|}
\hline \multicolumn{1}{|c|}{ Parameters } & Value & Units \\
\hline Load, $\mathrm{F}_{\mathrm{N}}$ & 15 & {$[\mathrm{~N}]$} \\
\hline Coefficient of friction in BL, $\mathrm{f}_{\mathrm{c}}$ & 0.16 & {$[-]$} \\
\hline Radius of the cylinder, $\mathrm{R}_{\mathrm{cyl}}$ & 2 & {$[\mathrm{~mm}]$} \\
\hline Length of the cylinder, $\mathrm{B}$ & 8 & {$[\mathrm{~mm}]$} \\
\hline Contact width, $2 \mathrm{~L}_{\mathrm{w}}$ & $12.8,100,200$ & {$[\mu \mathrm{m}]$} \\
\hline Viscosity & $\eta_{0}=0.065$ & {$[\mathrm{~Pa} \cdot \mathrm{s}]$} \\
Viscosity-pressure coefficient & $\alpha=2 \cdot 10^{-8}$ & {$[\mathrm{~Pa}$} \\
Eyring shear stress & $\tau_{0}=2.5 \cdot 10^{6}$ & {$[\mathrm{~Pa}]$} \\
\hline \multicolumn{2}{|l|}{} \\
\hline \multicolumn{2}{|l}{} \\
\hline
\end{tabular}

Table D. 5 Input parameters for the simulations of Figure 6.3.

\begin{tabular}{|l|c|c|}
\hline \multicolumn{1}{|c|}{ Parameters } & Value & Units \\
\hline Load, $\mathrm{F}_{\mathrm{N}}$ & 15 & {$[\mathrm{~N}]$} \\
\hline Coefficient of friction in BL, $\mathrm{f}_{\mathrm{c}}$ & 0.156 (from experiments) & {$[-]$} \\
\hline Radius of the cylinder, $\mathrm{R}_{\mathrm{cyl}}$ & 2 & {$[\mathrm{~mm}]$} \\
\hline Length of the cylinder, B & 8 & {$[\mathrm{~mm}]$} \\
\hline Contact width, $2 \mathrm{~L}_{\mathrm{w}}$ & unworn contact, $2 \mathrm{~L}_{\mathrm{w}}=12.8$ & {$[\mu \mathrm{m}]$} \\
& after $12 \mathrm{~h}$ and friction test, $2 \mathrm{~L}_{\mathrm{w}}=270$ & \\
\hline Lubricant parameters & Esso EZL 799 & \\
Viscosity & $\eta_{0}=0.065$ & {$[\mathrm{~Pa} \cdot \mathrm{s}]$} \\
Viscosity-pressure coefficient & $\alpha=2 \cdot 10^{-8}$ & {$\left[\mathrm{~Pa}^{-1}\right]$} \\
Eyring shear stress & $\tau_{0}=2.5 \cdot 10^{6}$ & {$[\mathrm{~Pa}]$} \\
\hline \multicolumn{2}{|l}{} \\
\hline \multicolumn{2}{|l}{} \\
\hline
\end{tabular}

Table D. 6 Input parameters for the simulations of Figure 6.4.

\begin{tabular}{|l|c|c|}
\hline \multicolumn{1}{|c|}{ Parameters } & Value & Units \\
\hline Load, $\mathrm{F}_{\mathrm{N}}$ & 15 & {$[\mathrm{~N}]$} \\
\hline Coefficient of friction in BL, $\mathrm{f}_{\mathrm{c}}$ & 0.137 (from experiments) & {$[-]$} \\
\hline Radius of the cylinder, $\mathrm{R}_{\mathrm{cyl}}$ & 2 & {$[\mathrm{~mm}]$} \\
\hline Length of the cylinder, $\mathrm{B}$ & 8 & {$[\mathrm{~mm}]$} \\
\hline Contact width, $2 \mathrm{~L}_{\mathrm{w}}$ & unworn contact, $\mathrm{L}_{\mathrm{w}}=12.8$ & {$[\mu \mathrm{m}]$} \\
& after $12 \mathrm{~h}$ and friction test, $\mathrm{L}_{\mathrm{w}}=280$ & \\
\hline Lubricant parameters & $\mathrm{Vitrea} 150$ & \\
Viscosity & $\eta_{0}=0.47$ & {$[\mathrm{~Pa} \cdot \mathrm{s}]$} \\
Viscosity-pressure coefficient & $\alpha=2 \cdot 10^{-8}$ & {$\left[\mathrm{~Pa}^{-1}\right]$} \\
Eyring shear stress & $\tau_{0}=2.5 \cdot 10^{6}$ & {$[\mathrm{~Pa}]$} \\
\hline \multicolumn{2}{|l}{} \\
\hline Surface topography from Figure 6.2 & \\
\hline
\end{tabular}


Table D. 7 Input parameters for the simulations of Figure 6.6.

\begin{tabular}{|l|c|c|}
\hline \multicolumn{1}{|c|}{ Parameters } & Value & Units \\
\hline Load, $\mathrm{F}_{\mathrm{N}}$ & 15 & {$[\mathrm{~N}]$} \\
\hline Coefficient of friction in BL, $\mathrm{f}_{\mathrm{c}}$ & 0.14 (from experiments) & {$[-]$} \\
\hline Radius of ball & 5 & {$[\mathrm{~mm}]$} \\
\hline Wear scar diameter, $2 \mathrm{~L}_{\mathrm{w}}$ & after 2h and friction test, $2 \mathrm{~L}_{\mathrm{w}}=366$ & {$[\mu \mathrm{m}]$} \\
& after $12 \mathrm{~h}$ and friction test, $2 \mathrm{~L}_{\mathrm{w}}=556$ & \\
\hline Lubricant parameters & Esso EZL 799 & \\
Viscosity & $\eta_{0}=0.065$ & {$[\mathrm{~Pa} \cdot \mathrm{s}]$} \\
Viscosity-pressure coefficient & $\alpha=2 \cdot 10^{-8}$ & {$\left[\mathrm{~Pa}{ }^{-1}\right]$} \\
Eyring shear stress & $\tau_{0}=2.5 \cdot 10^{6}$ & {$[\mathrm{~Pa}]$} \\
\hline \multicolumn{2}{|c|}{} \\
\hline \multicolumn{2}{|l|}{} \\
\hline
\end{tabular}

Table D. 8 Input parameters for the simulations of Figure 6.8.

\begin{tabular}{|c|c|c|}
\hline Parameters & Value & Units \\
\hline Load, $\mathrm{F}_{\mathrm{N}}$ & 10 & {$[\mathrm{~N}]$} \\
\hline Coefficient of friction in $\mathrm{BL}, \mathrm{f}_{\mathrm{c}}$ & 0.13 (from experiments) & {$[-]$} \\
\hline Radius of the spherical roller & $\begin{array}{l}\mathrm{R}_{\mathrm{x}}=4 \\
\mathrm{R}_{\mathrm{y}}=26.67\end{array}$ & $\begin{array}{l}{[\mathrm{mm}]} \\
{[\mathrm{mm}]}\end{array}$ \\
\hline Dimension of the contact ellipse & $\begin{array}{l}\text { after } 8 \mathrm{~h} \text { and friction test } \\
2 \mathrm{a}=170 ; 2 \mathrm{~b}=375 \\
\text { after } 40 \mathrm{~h} \text { and friction test } \\
2 \mathrm{a}=340 ; 2 \mathrm{~b}=840\end{array}$ & $\begin{array}{c}{[\mu \mathrm{m}]} \\
{[\mu \mathrm{m}]}\end{array}$ \\
\hline $\begin{array}{l}\text { Lubricant parameters } \\
\text { Viscosity } \\
\text { Viscosity-pressure coefficient } \\
\text { Eyring shear stress }\end{array}$ & $\begin{array}{c}\text { Esso EZL } 799 \\
\eta_{0}=0.065 \\
\alpha=2 \cdot 10^{-8} \\
\tau_{0}=2.5 \cdot 10^{6}\end{array}$ & $\begin{array}{c}{[\mathrm{Pa} \cdot \mathrm{s}]} \\
{\left[\mathrm{Pa}^{-1}\right]} \\
{[\mathrm{Pa}]}\end{array}$ \\
\hline
\end{tabular}




\section{List of publications}

Crăcăoanu, I. and Schipper D.J., "Influence of macroscopic wear on the Stribeck curve for line contacts" Bul. Inst. Polit. Iasi, Tomul LIV (LVIII), Fasc. 4, 2008, pp. 467-476.

Crăcăoanu, I. and Schipper D.J., "Friction behavior in worn lubricated sliding line contacts", Proceedings of the 65th STLE Annual Meeting \& Exhibition Conference, 2010 .

Crăcăoanu, I. and Schipper D.J., "Friction in worn lubricated circular contacts", Proceedings of the ROTRIB' 10 Conference, 2010.

Crăcăoanu, I. and Schipper D.J., "Influence of macroscopic wear on friction in worn sliding lubricated concentrated contacts. Part I: Theoretical prediction", submitted to Wear, 2010.

Crăcăoanu, I. and Schipper D.J., "Influence of macroscopic wear on friction in worn sliding lubricated concentrated contacts. Part II: Experiments/validations", submitted to Wear, 2010. 